
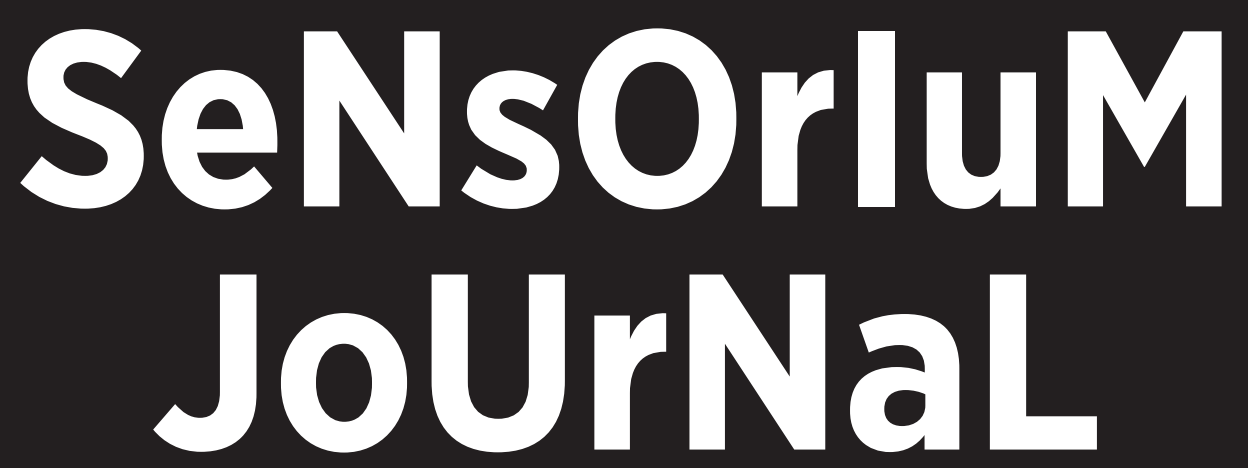

Nr. 2, 2017 
SENSORIUM JOURNAL 2, 2017

ISSN: 2002-3030

Utgivningsland: Sverige

Redaktörer: Ragnild Lome, Jakob Lien, Solveig Daugaard

Omslagsbild:

Typografi webb: Ragnild Lome

Typografi: Jakob Lien

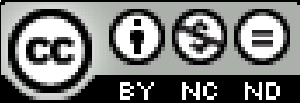


Contents

5. Solveig Daugaard, Jakob Lien and Ragnild Lome:

Editorial

9. A questionnaire:

What is Media Archeology?

35. Per Israelson:

The Sympoiesis of Superheroes

55. Sybille Krämer:

Hvorfor notationel ikonicitet

er en form for operationel ikonicitet

(Danish translation by Solveig Daugaard of the text "Notational (conicity")

81. Jakob Lien:

About Flatland and Flatland

85. Edwin A. Abbott:

Flatland (excerpt)

109. Derek Beaulieu:

Flatland (excerpt)

115. Jesper Olsson:

Skywriting, Signals, and Poetry Systems

125. Solveig Daugard:

The End of Progress on Earth
135. Jakob Lien:

Singing Satellites and Sounding Birds

Reviews:

143. Jenny Jarlsdotter Wikström:

Anna Tsing's The Mushroom at the End of the World: On the Possibility of Life in Capitalist Ruins

149. Johan Fredrikzon:

Tung-Hui Hu's A Prehistory of the Cloud

157. Ragnild Lome:

Mark Seltzer's The Official World

163. Contributors 



\section{Editorial}

"Since Sputnik, the planet has become a global theatre under the proscenium arch of man-made satellites. Our psyches acquire thereby a totally new rim-spin."

(Marshall McLuhan, Culture is our business, 1970)

With these words by Marshall McLuhan, you are hereby welcomed to the second issue of Sensorium Journal. This issue includes papers from the Geomedia conference in Karlstad 2017, about skywriting, singing birds, satellites and airplanes. In a media archeological vein, there are works on (artifical) flatness, the sympoiesis of comic books and reviews of challenging new theoretical titles by Tung-Hui Hu, Anna Tsing and Mark Seltzer.

The essay "Notational Iconicity" by professor of language and media philosophy at Freie Universität, Sybille Krämer, is translated into Danish by our editor Solveig Daugaard. Krämer, who 
is an honorary doctor at Linköping University, visited Östergötland in 2017 to discuss a series of texts related to her concept of "artifical flatness", one of which we are proud to present in this issue. Krämer's strikingly cogent take on some of the foundational questions of media philosophy regarding the intricate relations between thinking, speech and systems of written notation provide an interesting antipole to the somewhat wordier approach of many leading media theorists today. As an artistic spin to the theoretical ideas of Krämer, we confront it with an excerpt from the 1884-novel Flatland by British author and theologian Edwin A. Abbott, originally published under the witty alias "A Square" along with the visual reinterpretation of the novel by Canadian poet Derek Beaulieu from 2007, introduced by Jakob Lien.

One of the theoretical interests of the editors of this journal is media archaeology. For this issue, we therefore approached a number of scholars in Scandinavia who have worked with the concept, and asked them three questions we ourselves have struggled with. What is media archaeology in their view? How, more concretely have they used the media archaeological framework in their research? And how do they understand the relation between artefact and structure within media archaeology? In addition, we also asked our colleagues in the network to contribute and openly reflect on the same questions. The resultant survey gives the impression of a theoretical framework that - at least in the past decade - has played an intriguing role for media oriented aesthetic thinking in Scandinavia, and still has wide potential for exploration and further development for research in the field.

Since the last issue, Sensorium Network has organized two workshops. One about non-human languages in Umeå in 2016, and one about autopoiesis in Linköping in 2017. In addition, preparations have started, for transforming part of Sensorium 
Journal into a peer reviewed publication in 2018 . The journal will still be a place for collective writing and artistic contributions but will in addition feature a section of articles that have gone through a double blind referee process. Make no mistake! The idea behind the journal is still the same; the mixture of peer reviewed articles and the more open main section of the journal is meant to mirror the collaborative idea behind Sensorium.

The change in the structure of the journal also bear with it some very intriguing news: From the next issue on, Sensorium Journal will be equipped with a scientific board, whose members will be announced later this fall, as well as three new editors: Jenny Jarlsdotter Wikström is a doctoral student in comparative literature and gender studies at Umeå University, Johan Fredrikzon is a doctoral student in history of ideas at Stockholm University, and Per Isreaelson recently defended his thesis on the media ecologies of fantastic in literary history. We expect lots of fun, sharp and lively discussion as well as new initiatives to spring from their involvement as editors of the journal.

Enjoy Sensorium Journal 2!

Solveig Daugaard, Jakob Lien and Ragnild Lome 



\section{Vad är mediearkeologi? En enkät}

\section{THOMAS GÖTSELIUS}

\section{Institutionen för kultur och estetik, Stockholms universitet}

1. Vad är "mediearkeologi" enligt din åsikt? Är det en teori, en metod eller något tredje? (Hur förhåller sig begreppet till exempel till närliggande termer som mediehistoria, medieestetik, medieekologi och det post-digitala?)

"Samtidens arkeologier måste också ta hänsyn till lagring, överföring och beräkning av data i tekniska medier", skriver Friedrich Kittler i efterordet till Nedskrivningssystem 1800/1900. Även om Kittler själv inte myntade termen "mediearkeologi" så är detta textställe sannolikt så nära man kan komma dess födelseort. Andra, som Siegfried Zielinski och Wolfgang Ernst, kom senare att göra anspråk på neologismen, men vill man förstå mediearkeologin som fenomen så kan man inte bortse från att det uppkom ur behovet av att i efterhand namnge och klassificera de märkliga historiska undersökningar som Kittler utvecklade. 
Det är min uppfattning att mediearkeologin bör ses som ett kluster av teoretiska antaganden som sammantagna medför vissa metodologiska konsekvenser. Den klassiska, kittlerska mediearkeologin står således i ett spänningsfyllt - kritiskt! förhållande till såväl den linjära och historiografiskt oreflekterade mediehistorien, den ekonomihistoriskt eller humanistiskt orienterade kanadensiska medieekologin samt den historiskt underteoretiserade och fenomenologiskt orienterade medieestetiken. Oavsett om vårt nu är "digitalt" eller "post-digitalt", så skriver mediearkeologin dess historia.

\section{Hur, merkonkret, är begreppet användbart i din egen forskning?}

Faktum är att jag sällan aktualiserat termen. Det hänger inte samman med någon latent kritik mot densamma utan snarare mot en viss ovilja att låta mitt arbete på förhand riskera att reduceras till ett antal till synes givna frågeställningar eller positioner. I en viss fas börjar varje undersökning leva sitt eget liv och då gör man bäst $i$ att kapa banden till alla skolbildningar. I efterhand, när arbetet rotts i land, har jag förstås kunnat konstatera att man med rätta ändå kunnat beskriva mitt arbete $\mathrm{i}$ mediearkeologiska termer.

3. Mediearkeologin är intresserad av såväl de konkreta, historiska, teknologiska föremålen (artefakt), som de förändringar teknologierna medför i diskurser, praktiker, biopolitik, etc. (struktur). Hurförhandlar begreppet enligt din förståelse mellan artefakt och struktur?

I den klassiska mediearkeologin analyseras historiska diskursmängder i termer av informationssystem. I dessa system, som hos Kittler modelleras efter funktionerna i Shannons matematiska informationsteori, har enskilda artefakter eller medier en möjlig roll, men vilken eller vilka strukturella funktioner de tilldelas skiftar historiskt. Utväxlingen mellan artefakter och de strukturer de sätts på spel i måste därför beskrivas på en empirisk nivå. Min erfarenhet av sådana undersökningar har lärt mig att man samtidigt bör vara uppmärksam på att de reella 
systemen sällan lever upp till teorins modeller. Sammanbrott, motsägelser, skevheter och paradoxer tycks prägla de reella kulturella dataflödena. Att göra reda för dem är också en del av den mediearkeologiska uppgiften.

\section{JOHN BRUMO \\ Institutt for språk og litteratur, Norges teknisk-naturviten- skapelige universitet}

1. Vad är "mediearkeologi" enligt din åsikt? Är det en teori, en metod eller något tredje? (Hur förhåller sig begreppet till exempel till närliggande termer som mediehistoria, medieestetik, medieekologi och det post-digitala?)

Jeg oppfatter mediearkelologi som en mediehistorisk undersøkelse av estetiske uttrykk. Det er derfor kanskje riktigst å kalle det en metode. Denne metoden tar utgangspunkt i at medier og teknologi har stor innflytelse på måten vi oppfatter omverdenen på og muligheten til å uttrykke erfaringer. Hovedinspirasjonen for denne type tenkning kommer typisk fra Friedrich Kittler og særlig hans Aufschreibesysteme 1800/1900, men også en rekke andre tenkere og filosofer (for eksempel Walter Ong, Marshall McLuhan, Raymond Williams og Jonathan Crary) har pekt på lignende sammenhenger. Ingen har imidlertid formulert det like pregnant som Kittler: "Medien bestimmen unsere Lage" (i forordet til Grammaphon, Film, Typewriter). Det grunnleggende poenget til Kittler er at litteraturen (men forsåvidt også annen kunst) er underlagt mediehistoriske forutsetninger, noe som gjør at både alfabetet, skrivemaskinen og tekstbehandlingsprogrammet har betydning for hvordan litteraturen artikuleres. I dag - med de altomfattende digitale mediene - er jo dette utsagnet mye mer treffende enn det var da Kittler utviklet sin tenkning på 1980-tallet. Den mediehistoriske innfallsvinkelen åpner opp et merkelig lite påaktet felt, nemlig at lyd-, ord- og bildekunstene har benyttet seg av motiver og fremstil- 
lingsprinsipper fra samtidens medieformer. Bruken av ordet "arkeologi" kjennes likevel litt problematisk. Ikke fordi man hører et ekko av Foucault, men fordi det høres ut som om det må være sjeldne eller nedgravde medier som skal undersøkes, og fordi det jo ikke alltid er "funn" i helt objektiv betydning man gjør seg som forsker. Ofte handler mediearkeologien som metode om å kombinere innsikter fra mediehistorie og litteraturhistorie, og kan gjerne undersøke medier som fortsatt er i bruk.

\section{Hur, mer konkret, är begreppet användbart i din egen forskning?}

Mediearkelologiens styrke er å avdekke skjulte sammenhenger mellom medier, teknikker og estetikk. Siden så mye tidligere litteraturforskning har vært orientert mot ideer og filosofi, er det mye ugjort på dette feltet. I praksis er det også veldig interessant å jobbe med: Vi kan undersøke hvordan den visuelle kulturen preger Sigbjørn Obstfelders mest kjente dikt "Jeg ser", undersøke hvordan mediene preger modernismens gjennombrudd i Norge rundt år 1900 eller se på hvordan nye forfattergenerasjoner i dag bruker digitale medier i sin diktning. Det er bl.a. et vitalt miljø for denne type forskning ved min institusjon, i prosjektet "The Medial Breakthrough in Norwegian Literature 1855-1905". Men problemene må også nevnes. En åpenbar risiko med den mediearkeologiske praksisen, er risikoen for å bli fanget av en slags medie-determinisme og underspille de menneskelige mulighetene for innovasjon og evne til nyskaping. Et annet problem er faren for uforpliktende spekulasjon om sammenhengen mellom medier og kunst.

3. Mediearkeologin är intresserad av såväl de konkreta, historiska, teknologiska föremålen (artefakt), som de förändringar teknologierna medför i diskurser, praktiker, biopolitik, etc. (struktur). Hurförhandlar begreppet enligt din förståelse mellan artefakt och struktur?

Flere medieteoretikere har pekt på at mediene ikke kan analyseres enkeltvis, men utgjør et slags sammenhengende "system". Selv om ideen om medienettverket neppe har allmenn gyldighet 
til alle tider, er det fascinerende hvor aktuelle og relevante de grunnleggende prinsippene i McLuhans ideer om Gutenberggalaksen kan være i dag. Måten vi sanser og erfarer verden på i dag, er på mange vis helt annerledes enn tidligere tiders erfaringer. Mediearkeologien er en metode som er særlig egnet til å påvise disse sammenhengene og utviklingstrekkene.

\section{SOLVEIG DAUGAARD Institutionen för kultur och kommunikation, Linköpings Uni- versitet}

1. Vad är "mediearkeologi" enligt din åsikt? Är det en teori, en metod eller något tredje? (Hur förhåller sig begreppet till exempel till närliggande termer som mediehistoria, medieestetik, medieekologi och det post-digitala?)

Mediearkæologi er et perspektiv som særlig betoner de teknologiske omstændigheders betydning for en given historisk situation. Ind i mellem kan jeg godt, ikke mindst når jeg betragter den ganske begrænsede diversitet i forhold til køn, race, osv. i den internationale forskermasse på området, få den mistanke at det samtidig er blevet et tiltrængt forskningsmæssigt fristed, hvor den hvide akademiker helt ukontroversielt kan slippe for hele tiden at skulle problematisere sit eget kropslige udgangspunkt. Hvis medierne, som Kittler slår fast, determinerer vores situation, har så ikke kropslige og sociale forskelle en tendens til at glide i baggrunden som mindre væsentlige? Forlæser man sig på en mediearkæolog som Wolfgang Ernst virker en sådan observation måske ikke helt urimelig. Men kun hvis man glemmer Kittlers mellemværende med lacaniansk tankegods kan man fastholde den position, fordi bl.a. diffentieret kønskonstruktion er en afgørende bestanddel i den teknologiske determinering af Kittlers 'såkaldte menneske'. 
I min egen forskning er jeg optaget af hvordan ændrede teknologiske betingelser påvirker litteraturens medieøkologier. Her har det gang på gang slået mig, hvordan sådanne teknologiske betingelser påvirker kønnene forskelligt - ligesom de åbenlyst påvirker racialiserede kroppe anderledes end 'neutrale' hvide kroppe. Et banalt eksempel er forskellen på hvordan opblomstringen af en selfie-kultur med mobilteknologi og sociale netværksmedier, har påvirket idealerne for unge mænds og unge kvinders kropsfremstilling forskelligt, og, delvis afledt heraf, hvordan den fotografiske fremstilling af forfattere, i bøger og aviser såvel som på digitale platforme, har udviklet sig voldsomt i løbet af få år, men igen i helt forskellig grad for mandlige og kvindelige forfattere - og igen anderledes for såkaldt racialiserede forfattere. Som skriftmediet hos Kittler konstruerer kønsforskelle, konstruerer og forstærker de digitale medier diverse kropslige forskelle efter deres egne teknologiske logikker, som vi bør forsøge at blive klogere på.

For en overfladisk betragtning kan det virke som om mediearkæologien ikke har så mange svar på, hvorfor teknologiens konsekvenser rammer skævt i forhold til f.eks køn og race, men tværtimod, har jeg oplevet perspektivet som nyttigt i arbejdet med at udvikle et præcist og ikke-polariserende sprog for sådanne forskelle, hvilket gør det lettere at fastholde og betragte nogle forhold, som er vanskelige at diskutere når de bliver enten individualiserede eller entydigt hængt op på givne identitetspolitiske kategorier, fordi de så let bliver meget følsomme. I forhold til eksemplet med den fotografiske fremstilling af forfatteren, så er det ubehageligt, ofte nærmest krænkende, at påtale den enkelte forfatters iscenesættelse, ligesom det er dybt problematisk at kritisere f.eks. "kvindelige forfatteres" selvfremstilling i medierne, men hvis man tilgår forholdet fra de ændrede teknologiske forudsætningers udgangspunkt, har man et mindre eksplosivt underlag at starte sin diskussion fra, og kan få mulighed for at formulere nogle præmisser før ræsonnementet evt. går i identi- 
tetspolitisk hårknude. Det handler om at kunne pege på nogle forhold, og foreslå forklaringer som er teknologisk betingede, og således ikke rummer essentialistiske postulater i forhold til identitetskategorierne.

3. Mediearkeologin är intresserad av såväl de konkreta, historiska, teknologiska föremålen (artefakt), som de förändringar teknologierna medför i diskurser, praktiker, biopolitik, etc. (struktur). Hur förhandlar begreppet enligt din förståelse mellan artefakt och struktur?

Spørgsmålet er hvad en struktur er. Det er altid lettere at forholde sig til en konkret teknologi, et konkret netværk, en konkret teknologisk materiel situation end til en abstrakt struktur. Men mediearkæologien insisterer netop på den konkrete forekomsts fysiske forbindelse til struktureren, hvilket tvinger den til at tænke konkret, også i forhold til strukturer. Jeg kan dog komme i tvivl om hvordan andre typer af strukturer end de entydigt teknologiske, som for eksempel kønslige eller racemessige strukturer spiller ind i sammenhængen, men måske er mediearkæologien heller ikke nødt til at rumme det hele. Netop derfor oplever jeg det også som frugtbart at koble det mediearkæologiske perspektiv til andre strømninger, som affektteori samt diverse former for feministisk og postkolonial tænkning.

\section{JAKOB LIEN}

\section{Institutionen för kultur och kommunikation, Linköpings uni- versitet}

1. Vad är "mediearkeologi" enligt din åsikt? Är det en teori, en metod eller något tredje? (Hur förhåller sig begreppet till exempel till närliggande termer som mediehistoria, medieestetik, medieekologi och det post-digitala?)

Mediearkeologin är kanske i första hand ett perspektiv som rör sig mellan teori och metod. Något som på samma gång är dess 
främsta styrka och största svaghet. Mediearkeologin fungerar, när den görs teoretiskt operativ, som ett slags kartografi över sambanden mellan materialitet, medieteknologier, estetiska praktiker och, i bästa fall, även kultur- och samhällshistoria. Till skillnad från en mer traditionellt förekommande mediehistoria som stundtals har tenderat att reproducera en linjär, teleologisk utvecklingstanke i beskrivningen av relationen mellan teknologi och estetik, söker mediearkeologin upp de heterogena och icke-linjära sambanden. Med rötterna i Friedrich Kittlers mediebegrepp å ena sidan och Michel Foucaults sökande efter historiens lakuner å den andra har mediearkeologin kommit att ta delvis olika riktningar. På ena sidan återfinns Wolfgang Ernsts materiellt och strikt medieorienterade arkeologi (och kanske även Matthew Kirschenbaums forensiska medieundersökningar kan sägas höra hit), och på den andra finner vi Siegfried Zielinskis "variantologi" och "anarkeologi" som båda vidgar och löser upp gränserna för studiet av medier och de institutioner som organiserar dem, mot andra heterogena fält som konst, naturvetenskap, musik, teologi etc., samt Jussi Parikkas utgrävningar i de mediegeologiska sedimenten. Men arkeologin är inte enbart ett teoretiskt arv från Foucault, den är också en metod, eller åtminstone ett verktyg, för forskare och konstnärer att rent fysiskt, materiellt göra bruka av det teoretiska godset och närma sig det konkreta föremålet. Ofta för att skapa ett slags förståelse för hur en historisk tillämpning av en medieteknologi kan inverka på våra samtida praktiker och vice versa genom att närma sig medierna inte bara utifrån ett teoretiskt, utan även sensoriskt angreppsätt.

\section{Hur, mer konkret, är begreppet användbart $i$ din egen forskning?}

För mig har mediearkeologin blivit operativ på två nivåer: först har mediearkeologin på ett ganska banalt sätt varit fruktbar som en tankemodell som hjälper till att bibehålla ett kritiskt perspektiv på de medieteknologier och dess relation till olika estetiska praktiker jag studerat i min forskning. Men jag har även mer konkret försökt göra bruk av arkeologin för att förstå estetiska 
praktiker som tidigt arbetat med digitala teknologier, genom att tillsammans med en programmerare rent konkret närma mig obsoleta maskiner. Den konkreta, sensoriska erfarenheten, och inte minst alla de misslyckade försöken att få apparater att fungera och datorprogram skrivna på programspråk som ingen längre behärskar att fungera, har möjligen gjort en mindre benägen att skriva fram sömlösa, teleologiska sammanhang. Den har definitivt skapat en forskare med en dos mer ödmjukhet och en dos mer frustration.

3. Mediearkeologin är intresserad av såväl de konkreta, historiska, teknologiska föremålen (artefakt), som de förändringar teknologierna medför i diskurser, praktiker, biopolitik, etc. (struktur). Hurförhandlar begreppet enligt din förståelse mellan artefakt och struktur?

Mediearkeologin har stundtals trillat i samma fallgrop som den mediehistoria den från början kritiserade för att endast intressera sig för själva medierna genom att själv reproducera en fetischisering av själva artefakten. Om fokus för undersökningen är obsoleta och förträngda medier riskerar arkeologin snart att påminna om en antikhandlares jakt på unika objekt, snarare än kritisk forskning. För att mediearkeologin ska vara fortsatt relevant bör det främsta fokuset ligga på en strukturell/diskursiv, eller åtminstone praktikorienterad nivå. Detta utesluter inte föremålet/artefakten, eller rättare sagt dess materiella kvaliteter utan kopplar det till ett bredare sammanhang. Jag tror även att mediearkeologin skulle vinna på att i större utsträckning ta intryck av, eller korskopplas med, ett medieekologiskt perspektiv för att i högre grad kunna ta hänsyn till kulturella och samhälleliga aspekter, men även naturliga miljöer och icke-mänskliga agenter. På så sätt kommer även mediearkeologin att kunna göras politiskt verksam (när så behövs), en domän som den traditionella mediehistorien och till viss del även mediearkeologin inte riktigt velat befatta sig med. 


\section{JOHAN FREDRIKZON \\ Institutionen för kultur och estetik, Stockholms universitet}

1. Vad är "mediearkeologi" enligt din åsikt? Är det en teori, en metod eller något tredje? (Hur förhåller sig begreppet till exempel till närliggande termer som mediehistoria, medieestetik, medieekologi och det post-digitala?)

Mediearkeologi är i första hand en kreativ sammansättning av fenomen/områden/discipliner vars effekt i bästa fall blir att man tvingas tänka längs nya linjer eller följa oväntade kurvor inom det område man sysslar med. Det är detta som akademin blivit bättre på sedan den lärt sig från managementkonsulterna att verklig innovation alltid äger rum genom att kombinera kända ting på lagom nya sätt och lansera det som något fullständigt okänt (en praktik som mediearkeologin själv lärt känna i sitt källmaterial). Här kan man testa lite själv och känna var någonstans det rasslar till: rättsantropologi, matematisk sociologi, statistisk psykologi, feministisk kosmologi, kognitiv fysik, queerlingvistik, ingenjörsetnologi. Var inte till exempel litteratursociologi en sådan kittlande sammanslagning en gång i tiden?

Gränsen mellan krystade och produktiva begreppssammanslagningar kan vara smal. Mediearkeologi är rätt lyckat, tycker jag, eftersom det sätter fingret på något som man både kan och borde syssla med. För mig är det varken en teori eller en metod - teoretiskt är det inte tillräckligt solitt och metodologiskt lite fladdrigt. Det är istället just ett perspektiv, ett förslag för hur man kan vända blicken mot nya material. I praktiken blir det "ett sätt att se" inom mediehistoriska intressen där det arkeologiska pekar mot en utgrävning som går djupare ner i sedimenten och rotar runt i dammet och gruset efter saker som är mer gömda än det som mediehistoria normalt finner.

När mediearkeologin väl kommit upp från gropen med sina fynd, har den oftast blivit så förtjust över hur lustiga och märkvärdiga och på alla sätt annorlunda dessa märkligheter är att 
den kommit att börja älska sina material och därmed blivit rejält upptagen av deras quirkiness, vilket pekat vidare mot medieestetiska intressen: att vältra sig i det estetiska hos det som glömts bort, blivit fel, hamnat på avvägar. Därför har mediearkeologin kommit att syssla med dessa mediehistoriska återvändsgränder som ett slags upprättelse åt bortglömda medier i den queera estetikens namn. Här riskerar man att bli irrelevant $i$ andra avseenden, förstås, men att rota fram gårdagens bortglömda, tokiga, tekniska prylar har ju sitt värde, trots allt. Ändå är det inte förvånande att mediearkeologin kanske mer och mer pekar iväg åt tre olika håll: 1) infrastructure studies, där det handlar mer om att gräva i det strukturella än i det apparat-orienterade (vilket i sig är en utveckling från mediesystem-tänkande); 2) ecological media, där det breda mediebegreppet som från början var underförstått inom mediearkeologin kombinerats med antropocen-begreppets aktualitet och därför vänder på 'media ecology' som ju är typ samma sak som mediasystem-perspektivet; samt 3) 'medieontologi' som jag inte vet om någon pratar om, men jag menar det som Wolfgang Ernst håller på med: att hitta mediernas egen tid och utbredning, på deras 'egna villkor' där den bästa mediearkeologin är bandspelaren själv och så vidare. Det vill säga en rörelse som är besläktad med Actor-Network-Theory inom STS och human-animal studies och posthumaniora $\mathrm{i}$ USA, dvs. att diskutera hur aktörskap förhandlas, i det här fallet mellan den så kallade människan och maskinen, vilket i sig ser ut som ett slags återgång till Kittler och prylmagasinen i Humboldtkällaren i Berlin efter allt som kulturteknikerna i Weimar har uträttat för att balansera teknikvurmen (utan att släppa den, där det är motiverat). Dessa tre ser jag som utväxter från mediearkeologin vilket betyder att det queera apparatsvärmeriet kanske får nöja sig med att i bästa fall sufflera dessa och andra mediehistoriska arbeten (3:an kanske inte ens är historisk). Det post-digitala, för övrigt, ser mest ut som en begreppslek i genren: ta det nya och påstå att det är gammalt. Visst finns det en analog revival som en reaktion på digital ubikvitet men det post-digitala måste vara något mer än ett sätt att uttrycka detta för att motivera sin existens. Kanske har jag bara ingen koll där. 
Jag tyckte nog att de delar av mediearkeologin som inte handlade om tokiga prylar var mest intressant, men det är svårt att se vad som finns där som inte 1, 2 eller 3 ovan kan ge. Men då har mediearkeologin, som jag ser det, tjänat som en föregångare för att de här skulle uppstå eller bli tydligare/starkare. Gott så. Det finns emellertid alltid ett värde av att ordentligt gräva fram singulära grejer ur det förflutna. Men då krävs att man gör något ordentligt produktivt av det rent analytiskt också, dvs. något långt utöver att förundras över gårdagens märkvärdiga uppfinningar. Annars blir det lätt "Mediehistorieätarna".

3. Mediearkeologin är intresserad av såväl de konkreta, historiska, teknologiska föremålen (artefakt), som de förändringar teknologierna medför i diskurser, praktiker, biopolitik, etc. (struktur). Hur förhandlar begreppet enligt din förståelse mellan artefakt och struktur?

Som sagt, tycker jag nog att mediearkeologin fastnat i artefakterna och misslyckats i struktur-hänseende, vilket för mig blir orsaken till varför de som höll på med mediearkeologi för fem år sen nu sysslar med 1, 2, 3 eller kanske digital humaniora som snart kommer att uppträda som en behemoth och svälja allt det andra i sin väg som därmed blir allt och inget så att vi måste uppfinna nya kreativa sammansättningar som förklarar vad vi håller på med. Att mediearkeologi är dött - om det nu är det så har det uträttat åtskilligt bra de senaste åren. Kanske är det dags för vetenskapshistoriker och -sociologer att sätta tänderna i mediearkeologins uppgång och fall?

\section{SØREN POLD}

\section{Institut for Kommunikation og Kultur, Aarhus Universitet}

1. Vad är "mediearkeologi" enligt din åsikt? Är det en teori, en metod eller något tredje? (Hur förhåller sig begreppet till exempel till närlig- 
gande termer som mediehistoria, medieestetik, medieekologi och det post-digitala?)

Mediearkæologi kan opdeles i tre faser: Den tidligere mediearkæologi opstod i 1980 'erne '90'erne og blev en måde at forholde sig til nye medier som noget, der ikke bare var nyt og en 'revolution'. Fx tydeliggjorde mediearkæologiske studier, at virtual reality og $3 \mathrm{D}$ havde en historie tilbage til 1800 -tallets nye medier som panorama og stereoskop. Medie- og teknologihistorien var således ikke kun en lineær fremskridtshistorie, men en serie af genkomne topoi og utopier, som gentages med forskellige teknikker, som Erkki Huhtamo har fremstillet det. Mediearkæologien åbnede således også øjnene for teknologier, som umiddelbart mislykkedes og uddøde - dead media -, men som ikke desto mindre kunne være interessante at studere, og som ofte dukker op igen i nye udformninger. Senere er mediearkæologien blevet tæt knyttet til en ny form for materialisme og en ide om, at man kan læse historien ud fra mediernes teknik, fx hos Wolfgang Ernst. Endelig kobles mediearkæologien aktuelt med det post-digitale ud fra ideen om, at den digitale revolution er forbi, og der ikke længere er tale om en entydig forbindelse fra gamle (analoge) medier til nye digitale medier, men oftere en gensidig udveksling og indlejring. Mediearkæologien bliver et design, hvor gamle mediers udtryk bruges i nye mediers design, som $\mathrm{fx}$ analoge filtre i digitale fotografier på Instagram. Mediearkæologien er for mig en form for mediehistorie, som ikke er lineær og kausal, og som godt kan skrive tabernes og de døde mediers historie.

\section{Hur, mer konkret, är begreppet användbart i din egen forskning?}

Jeg er inspireret af alle tre faser. Først hjalp mediearkæologien mig (og andre) til at få et (kulturhistorisk) greb på nye medier. Siden tydeliggjorde mediearkæologien, at relationerne mellem materialitet og betydning er mangetydige. Aktuelt er mediearkæologien med til at give perspektiv på en kultur og en teknologi, hvor det digitale ikke længere blot erstatter noget 
gammelt/analogt, men hvor nye og gamle medier indgår i stadig nye transformationer, og hvor digitale medier også er blevet historiske og ruinøse og derfor kan bruges til at gentænke og -designe den aktuelle medievirkelighed.

3. Mediearkeologin är intresserad av sãväl de konkreta, historiska, teknologiska föremålen (artefakt), som de förändringar teknologierna medför i diskurser, praktiker, biopolitik, etc. (struktur). Hur förhandlar begreppet enligt din förståelse mellan artefakt och struktur?

Interfacet som en teknologisk kobling af materiale/signal og struktur/tegn er et hovedbegreb i min forskning inden for interfacekritik, digital kultur og kunst, og for mig er den kobling mellem materielle/funktionelle og semiotiske/repræsentationelle dimensioner computerens vigtigste kulturelle og samfundsmæssige udfordring. Jeg er interesseret i hvordan teknologiske artefakter instrumentaliserer og kobles med kulturelle strukturer, og jeg tror grundlæggende ikke på, at vi bliver klogere på digitale medier, hvis vi ikke holder fast i den dobbelthed, som ligger i interfacet. Jeg synes mediearkæologien er mest interessant, når den fritlægger konkrete koblinger mellem artefakter og strukturer, mellem teknik og kultur. For mig er den interessante mediearkæologi en mediexstetik - en måde at sanse medierne på, deres diskurser, ideologier, historie og kunst. Mediearkæologien balancerer, når den er mest interessant, mellem historisk interesse for gamle medier og teknisk nørderi - en måde at undres over både fortid, nutid og fremtid, gerne på en gang.

\section{RAGNILD LOME}

Institutionen för kultur och kommunikation, Linköpings Universitet

1. Vad är "mediearkeologi" enligt din åsikt? Är det en teori, en metod eller något tredje? (Hur förhåller sig begreppet till exempel till närlig- 
gande termer som mediehistoria, medieestetik, medieekologi och det post-digitala?)

Mediearkeologien er vel først og fremst en særlig gren av mediehistorien, men begrepet brukes på mange måter, og er stadig i bevegelse et nytt sted hen, og jeg føler på ingen måte at jeg har oversikt over hele begrepets rekkevidde. Kanskje på grunn av denne usikkerheten, har jeg endt opp med å se på det som en slags historisk medieteknologisk metode for mitt eget fag - litteraturvitenskapen -: ett sett med briller man kan ta av og på under undersøkelsen av tekster, som forankrer de filosofiske og estetiske artefaktene i sin motsetningsfulle mediehistoriske situasjon. Mediearkeologien postulerer ikke kausale koblinger mellom medier i en gitt tid, og trekker heller ikke lineære historiske linjer opp til vår egen tid. Mediearkeologien oppfordrer snarere forskeren til å forbli i kaoset som utgjorde fortidens mediesituasjon. Kartleggingen av kaoset er i seg selv interessant, og for å forstå og dra nytte av datidens estetiske, politiske og eksistensielle diskusjoner, er mediearkeologien veldig brukbart.

\section{Hur, mer konkret, är begreppet användbart i din egen forskning?}

Mediearkeologien som metode gir et nytt resonansrom til litteraturhistorikeren: Litteraturen forholder seg ikke bare til litteraturhistorien, og kan heller ikke utelukkende forstås som en refleksjon over sitt eget (skrift)medium. Litteraturen reagerer på, reflekterer over, opponerer mot og stimulerer til medieteknologiske endringer i et videre perspektiv. Mediearkeologien setter litteratur og filosofiske argumenter i sammenheng med en uartig samling av tekster, teknologier og materialer; tekniske manualer, teleinfrastrukturen, laterna magica, stortingsdokumenter eller avisenes rapportering av den teknologiske utviklingen. Kanskje er dette grunnen til at medieøkologi-begrepet har sneket seg inn nesten overalt hvor mediearkeologi diskuteres i dag: Begge perspektivene legger et medialt tverrsnitt på estetiske objekter, som gjør at avhengigheten av andre medier og medieinfrastrukturer kommer til syne. 
3. Mediearkeologin är intresserad av såväl de konkreta, historiska, teknologiska föremålen (artefakt), som de förändringar teknologierna medför i diskurser, praktiker, biopolitik, etc. (struktur). Hur förhandlar begreppet enligt din förståelse mellan artefakt och struktur?

I mine øyne er det en ganske opplagt kobling mellom vår tids akademiske buzzword, the non-human turn, og mediearkeologien, og tenker man disse to sammen, oppstår ingen motsetning mellom artefakt og struktur. Så lenge man er åpen nok om hvem/hva som kan være i stand til å påvirke utviklingen av en artefakt, ender man til slutt med å italesette (infra)strukturen på en eller annen måte. "Follow the actors", som Bruno Latour sier. Her oppstår nye problemer: ikke lenger hvor grensen går mellom artefakt og struktur, men hvor man skal avrunde nettverket i sin analyse.

En beslektet fundering er hva første del av ordet mediearkeologi - medier - egentlig dekker over i siste ende. Hvis man vil følge aktørene, hvor går grensen mellom en jernbaneswitch og en nettverkswitch, og hvor går grensen mellom avtrekkeren på en pistol og avløseren på et kamera? Det er kanskje denne metodisk forankrede forvirringen mellom nivåer av estetikk, medieteknologi og dypereliggende industrielle, militære og økonomiske utviklinger, som gjør mediearkeologien så fruktbar å jobbe med. Men også frustrerende.

\section{JESPER OLSSON}

\section{Institutionen för kultur och kommunikation, Linköpings uni- versitet}

1. Vad är "mediearkeologi" enligt din åsikt? Är det en teori, en metod eller något tredje? (Hur förhåller sig begreppet till exempel till närliggande termer som mediehistoria, medieestetik, medieekologi och det post-digitala?) 
Både och - och kanske något tredje. Utan tvekan erbjuder mediearkeologin (i den mån den låter sig identifieras som fält) olika sätt och metoder att utforska mediernas historier, sätt att förstå och problematisera en samtida kultur och dess mediala sammansättningar. Å ena sidan ger mediearkeologin incitament till en synkront organiserad analys av mediernas sammansatta materialitet och hur denna påverkar innebörder, funktioner, praktiker och så vidare, å den andra skapas förutsättningarna för en genealogisk och diakront anordnad analys som söker upp avvägarna och stickspåren i historien - mediekyrkogårdar etc. - med det uttalat kritiska syftet att problematisera teleologiska framgångshistorier. I bägge fallen spelar Foucaults analyser en avgörande roll, liksom Friedrich Kittlers och Wolfgang Ernsts arbeten. Den senares ambition att problematisera traditionell medie- och kulturhistorias mer eller mindre släta narrativ är viktig och försöker också på allvar dra (de allt annat än friktionsfria) konsekvenserna av de teoretiseringar som görs i namnet av en arkeologi. Även om detta ställer metodiska (och epistemologiska) problem på sin spets - exakt vad kan vi veta och yttra om maskinens egen ontologi? - kommer optimalt nya frågor och perspektiv också att tvingas fram. Och därmed ny kunskap om mediernas sätt att operera. Att teori pågår är alltså givet. Det mest intressanta metodologiska elementet gäller den experimentella - i medielabbet utövade - mediearkeologin. Här handlar det om historieforskning med ambitionen att genom en sinnligt och kognitivt sammansatt och materiell praktik konstruera "epistemiska objekt" som kan ge perspektiv på både det förflutnas och samtidens medieanvändning. Den mest påtagliga bristen hos Ernst och en del andra gäller den politiska analysen - här kan den vidgade mediematerialitet man finner hos John Durham Peters, Jussi Parikka, Sean Cubitt och andra bli viktig, vilket leder vidare till en mediernas geologi och ekologi, och till analyser av mer omfattande ekologier. Vad gäller det post-digitala, tror jag att begreppet säkert kan ha en tillfällig och strategisk funktion, för att ge resonans åt reflektionen kring digitala nätverk, teknologier och estetiker idag, men att det kanske också bör betraktas som ett slags delmängd eller kanske snarare effekt av det mediearkeologiska perspektivet. 
Främst har begreppet "mediearkeologi" varit användbart för att ge namn åt och upprätta villkoren för en analys av estetiska verk och praktiker som utforskar både sammankopplingar och glapp mellan olika medieteknologier och mediala miljöer - inte minst boken och digitala medier. Men jag har även försökt - eller har åtminstone förhoppningen om - att med begreppet kunna skapa förutsättningar för en mer experimentell och labb-baserad mediearkeologi $\mathrm{i}$ anslutning till min egen forskning.

3. Mediearkeologin är intresserad av såväl de konkreta, historiska, teknologiska föremålen (artefakt), som de förändringar teknologierna medför i diskurser, praktiker, biopolitik, etc. (struktur). Hur förhandlar begreppet enligt din förståelse mellan artefakt och struktur?

Kanske finns en tendens - och en risk - till fetischering av medier som tekniska artefakter hos mediearkeologin. Det är egentligen den risk för en avsaknad av politik som jag nämner redan ovan och den har att göra med ett alltför begränsat fokus på objektet. Men i realiteten kommer de flesta mediearkeologiska analyser hos Parikka, Zielinski och många andra - att också belysa frågor om affekt och biopolitik. Ändå kan jag se vinsten med att just på denna punkt berika mediearkeologin med ett begrepp som "ekologi", som i högre grad betonar relationalitet och händelser än de om än mycket fascinerande objekten i samlingar och arkiv.

\section{KNUT OVE ELIASSEN \\ Institutt for språk og litteratur, Norges teknisk-naturvitenska- pelige universitet}

1. Vad är "mediearkeologi" enligt din åsikt? Är det en teori, en metod eller något tredje? (Hur förhåller sig begreppet till exempel till närliggande termer som mediehistoria, medieestetik, medieekologi och det post-digitala?) 
Med mediearkeologi forstår jeg en bestemt analytisk fremgangsmåte som med utgangspunkt i Michel Foucault, Friedrich Kittler og Siegfried Zielinski bestreber seg på å bestemme de teknologiske premisser som regulerer systematikken i og premissene for informasjonsoverføringen/-lagringen i en nærmere bestemt historisk medieøkologi. Mediearkeologien skiller seg fra mediehistorien ved å fremheve praksisenes og artefaktenes epistemologiske egenverdi, ettersom denne ikke lar seg omsette fullt ut i diskurs eller fortelling (til dette kan man tilføye at arkivenes historie ikke restløst lar seg innordne i historiefaget narrative skjema). Det aktualiserende aspektet ved den mediearkeologiske analysen er at den leverer kontraster til og dermed perspektiver på aktuelle transformasjoner i samtidens medieøkologi. Slik er den mediearkeologiske analysen gjerne genealogisk konstruert slik at dens bærende problemstillinger og epistemologiske gjenstand er bestemt av en aktuell mediepolitisk konstellasjon.

\section{Hur, mer konkret, är begreppet användbart i din egen forskning?}

Jeg har selv i første rekke benyttet begrepet i litteraturhistoriske arbeider, dels med 1700-tallets brevroman spesifikt og den moderne romanens genese generelt, dels har jeg interessert meg for begrepets forskjellige konfigurasjoner i den såkalte tyske mediearkeologiske tradisjonen, og endelig har jeg interessert meg for mediebegrepets historie. For tiden retter min interesse seg først og fremst mot de maritime medier i tidlig moderne tid og de representasjonsteknologier som har blitt brukt til å kartlegge verdenshavene.

3. Mediearkeologin är intresserad av såväl de konkreta, historiska, teknologiska föremålen (artefakt), som de förändringar teknologierna medför i diskurser, praktiker, biopolitik, etc. (struktur). Hur förhandlar begreppet enligt din förståelse mellan artefakt och struktur?

Rekkevidden av begrepet "struktur" er langt fra entydig og utstyres med forskjellige funksjoner og innholdsbestemmelser av- 
hengig av det teoretiske "miljø" (eller økologi) det er operativt innenfor. For egen del vil et bestemt teknologisk artefakt, for eksempel en penn, dens tilhørende skriveunderlag, de arbeidsteknikker den fordrer (skrivestiler, alfabeter), de institusjoner den er operativ innenfor (skoler, byråer, offentlige arkiver etc.), alltid inngå i en dynamisk relasjon til de teknologier som omgir den og utgjør dens mediemiljø (postvesen, skrivestuer, private arbeidsværelser, men også radio, tv, pc, etc), samt de øvrige systemer som omslutter den i en engere betydning av mediale kretsløp (produksjon av materielle goder, juridiske regimer, bio-politiske dispositiver etc.).

\section{PELLE SNICKARS \\ Institutionen för kultur- och medievetenskaper, Umeå univer- sitet}

1. Vad är "mediearkeologi" enligt din åsikt? Är det en teori, en metod eller något tredje? (Hur förhåller sig begreppet till exempel till närliggande termer som mediehistoria, medieestetik, medieekologi och det post-digitala?)

Jag började att intressera mig för det mediearkeologiska forskningsfältet åren före millennieskiftet. Som doktorand var jag ställvis baserad i Berlin under sent 1990-tal, och kom på så vis i kontakt med den tyska medieforskning som på lite olika sätt byggde vidare på Kittlers idéer. Framför allt var det Wolfgang Ernst arbeten som jag då började att intressera mig för eftersom jag då också sysslade med mediearkivariska spörsmål (och sedermera började att arbeta på Statens ljud- och bildarkiv). Av en händelse var jag senare också på plats när Humboldtuniversitetet 2004 anordnade konferensen "Allgemeine Archäologie: Kulturtechniken zwischen Vergangenheit, Gegenwart und $\mathrm{Zu}-$ kunft". Då hade det mediearkeologiska forskningsfältet börjat att ta form på allvar, och jag var (nog) en av de första svenska humanisterna som introducerade begreppet mediearkeologi och 
började använda mig av det - bland annat i en understreckare i $S v D$ och senare i längre artiklar i en bok om Stockholmsutställningen 1897 samt i tidskriften Arkiv, samhälle och forskning.

För mig har mediearkeologi främst varit ett begrepp med en sorts dubbel innebörd: dels som ett slags historisk metod att frilägga olika, annorlunda, bortglömda eller rentav gråa och oansenliga medieformer bortom de traditionella massmedierna - något som jag intresserade mig för redan i min avhandling (Svensk film och visuell masskultur 1900 (2001)) vilken försökte att spåra svensk visuell mediekultur som till exempel vykort, stereobilder, panoramor och tittskåp vid sidan av filmen kring 1900; dels som en teori vilken strängt poängterar behovet att analysera det mediespecifika hos varje medieform. Mediehistoriens kommunikationsformer medierar på högst olika sätt - vilken den traditionella mediehistorien ofta glömmer bort eller tar för givet eftersom den ofta är monomedial. Att exempelvis filmen representerar på ett specifikt sätt (diegetiskt och/eller dokumentärt) är så självklart inom filmvetenskapen att det inte skrivs ut. Men jämför man filmen med stereobilden eller vykortet blir det uppenbart att det finns olika medieringspraktiker som är strikt specifika (även om de kan te sig som snarlika). Mediearkeologin har alltid varit ett sätt att få korn på sådana glidningar.

Det intressanta från mitt eget forskningsperspektiv - som med tiden blivit alltmer digitalt (om än också fortsatt mediehistoriskt orienterat) - är att jag sent insåg de sätt som mediearkeologin också kunde användas i en samtida kontext. För några år sedan höll jag ett längre föredrag i Trondheim på Norsk medieforskerlags konferense 2014 på temat och skrev då så här:

"I did a lot of media archaeological work a decade ago. Still, I failed to see the apparent linkage between the old media I was interested in, and the rapid changes among all new digital media forms occurring at the time, as the establishment of web 2.0 or the rise of Google. Parikka has repeatedly stated that from his perspective, media archaeology has great potential as a method for doing digital culture 
research. In that sense, media archaeology has been one thing - and is now within the broader domain of digital and internet based culture becoming and developing into something else. Borrowing from Mieke Bal's notion of doing interdisciplinary cultural analysis in the humanities, media archaeology can, thus, be seen as a traveling theory and mobile concept, situated in the intersection between past and present. In general, there is also now a temporal division among studies within media archaeology - and some are more or less prone to apply the term to what they do. There are, one the one hand, those who focuses on older and even dead media forms, as Erkki Huhtamo, and on the other those who do variations of media archaeology in a digital context, as for example Matthew Kirschenbaum's work, without explicitly labelling it as such. However, linkages towards the past is often a prerequisite also for the latter studies. In fact, media archaeology tends to stress as one of its central premises alternative genealogies for the development of technology over time. These alternatives often take the form of a critique of chronological and linear perspectives - that is, a critique of traditional ways of doing history and/or media history where certain periods and media, for example, are often connected in teleological ways. In opposition, media archaeology stresses other conceptualizations of temporality - both on a macro and micro level. Siegfried Zielinski's deep time of the media, for example, explores the technology of devices for hearing and seeing through two thousand years of cultural and technological history - often in rather unexpected ways. And in the case of Wolfgang Ernst, he often focuses on micro temporalities within media technology per se. How do you go about not writing media history, was the provocative question he posed a couple of years ago in a recently translated article entitled, "From media history to Zeitkritik". Ernst argues that media temporality is not to be understood only through the cultural history of media technologies, but also how media technologies themselves produce time. Machines have their own specific temporality, according to him - so called, Eigenzeit. It can be traced historically, and Ernst discusses radio in particular, but the ideas are better understood, I would argue, in relation to computational media. Code, for instance, might appear linear - but its functionalities are often inscribed in various forms of loops and algorithmic proce- 
dures - that is step-by-step procedures for calculations - with an inherent temporality that differs from chronological time. So called $r e-$ cursive subroutines, where computational implementations reference themselves, is another example. In other words, there exists a different conception of time on the micro-level of technology - within the computational medium. The media archaeological emphasis put on media specificity regarding the past, following my example from the 1897 exhibition, can thus also be found in the more digitally oriented media archaeology, which often tries to look under the hood of contemporary technology. This kind of scholarly focus can rapidly become very technical, making arguments hard to follow for a traditional humanist. Perspectives sometimes resemble what is known as digital forensics, where one goes deeper and deeper into the materiality of information technology, in order to recover or investigate material and information found in digital devices. In this sense, media archaeology is part of a gradually shifting emphasis from, say, the immaterial textual aspects of media culture to more media specific readings of the computational base - that is, mathematical structures - underlying actual hardware and software, a transition that resonates with some media scholars interest in technically rigorous ways of understanding the operations of material technologies."

\section{Hur, mer konkret, är begreppet användbart i din egen forskning?}

Mediearkeologi är en term, en metod, en teori som överbryggar studier av mediehistoriska perioder med mer samtida digitala mediestudier. Framför allt gäller det olika slags mediespecifika analyser av hur kod och programvara idag fungerar. I ett pågående projekt om Spotify använder jag mig exempelvis inte sällan av en mediearkeologisk vokabulär för att få korn på och förstå hur Spotifys musikalgoritmer egentligen fungerar.

Samtidigt har jag också distanserat mig från den mer strikta form av teknologiskt orienterad mediearkeologi som exempelvis Ernst står för. Begreppet är såtillvida framför allt användbart i min egen forskning som ett slags glasögon; ett sätt att betrakta medieformer på ett specifikt sätt - vilket om inte annat 
är av vikt inom det medie- och kommunikationsvetenskapliga fältet där jag själv (något motvilligt) är verksam, där studier av medier och demokrati eller massmedial representations- och effektforskning i princip alltid reducerar medier till en sorts svävande "texter".

3. Mediearkeologin är intresserad av såväl de konkreta, historiska, teknologiska föremålen (artefakt), som de förändringar teknologierna medför i diskurser, praktiker, biopolitik, etc. (struktur). Hur förhandlar begreppet enligt din förståelse mellan artefakt och struktur?

Det är ungefär detta jag menar med begreppets dubbla innebörd - som jag finner produktiv.

\section{JACEK SMOLICKI \\ Institutionen för konst, kultur och kommunikation (K3), Mal- mö högskola}

1. Vad är "mediearkeologi" enligt din åsikt? Är det en teori, en metod eller något tredje? (Hur förhåller sig begreppet till exempel till närliggande termer som mediehistoria, medieestetik, medieekologi och det post-digitala?)

As I see it, media archaeology is foremost a specific approach to or a mode of studying media. It is a certain sensitivity towards material and historical complexity that characterizes every media technological device, and more importantly, every media technological practice. I have had a hard time accepting media archaeology as a mode of studying objects, machines and devices perceived as closed entities somewhat extracted from their cultural, political and social contexts. I believe that media technologies always evolve, appear and thus also ought to be studied through relations with other actors and contexts. If so, perhaps we should speak rather of archaeologies of mediation in which the object of study is not merely the media artefact's 
internal configuration of elements and procedures, but a complex, messy and incommensurable mesh of relations (natural, environmental, cultural, bodily, ritualistic, etc.), that the object of study will enter, establish, disrupt or evade. Archaeology, as a study through the recovery of material culture is a messy practice always taking place in-situ. Yet, media archaeology often appears as a laboratory-like, sterile dissection and examination of objects removed from their contexts. Maybe this explains why what makes media archaeology more interesting and renders it more reliable, is its practical articulation through artistic and non-artistic forms of engagements with technologies.

\section{Hur, mer konkret, är begreppet användbart i din egen forskning?}

In my research, I use media archaeology in two ways. Firstly, as a renegade method for traversing historical trajectories of technological developments in search of examples of technologies and technological practices (or their aspects) that could inform our current condition. By informing, I mean two things: firstly, inspiring some hints and constructive indications for how to live with technologies, and secondly, critiquing by allowing to see the current states of technological development as not necessarily any better than the preceding but perhaps even the opposite. The second use of media archaeology relates to the constructive indication it provides. I resort to old technologies and practices in order to reincarnate them, or recall some of their attributes in the context of present technologies. I also look at non-mainstream discourses on and reactions to new technologies arriving at a given, historical moment. I search for examples of non-mainstream uses of these new technologies, and ambitious and non-compliant ways of incorporating them into the currents of everyday lives. This way, I am trying to seek in them some degree of inspiration for developing hybrid, idiosyncratic practices in today's context.

3. Mediearkeologin är intresserad av såväl de konkreta, historiska, teknologiska föremålen (artefakt), som de förändringar teknologierna 
medför i diskurser, praktiker, biopolitik, etc. (struktur). Hur förhandlar begreppet enligt din förståelse mellan artefakt och struktur?

I prefer the term network, or maybe even assemblage, as these terms move beyond the sense of statism that "structure" entails. Objects become objects in networks and through actively participating in forming relationships with other elements of these networks. 


\section{The Sympoiesis of Superheroes}

\section{Per Israelson}

In the following I want to address the posthumanist and participatory aesthetics of the comic book Black Orchid (1988), written by Neil Gaiman and illustrated by Dave McKean.

Through the neocybernetic concept sympoiesis, the comic book Black Orchid can be understood as a media ecology, where the feedback between the reader and the material environment of the comic book emerges as a distributed cognition. I will argue that the reader of the comic book participates in the production of aesthetic experience, and, more importantly, that this participation is not only a question of joining in on the hermeneutic circle, where the reader interprets the comic book and cre-

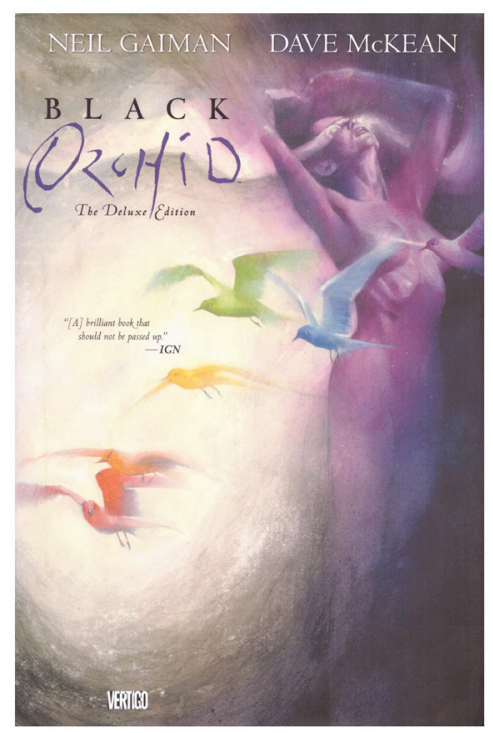


ates a storyworld. From a media-ecological perspective, aesthetic participation is also material and embodied; it is a question of participating in the emergence of an environment. In such a reading, Black Orchid tangibly stages an act of becoming, an event of ontogenesis.

The superhero character Black Orchid was introduced in the DC line Adventure Comics in 1973. In its original run Black Orchid comes forth as a typical crime fighting superhero of the detective comics variety; working in an urban setting, she is an adamant supporter of the disenfranchised, protecting their civic rights against the ruthlessness of crime bosses. Although her superpowers stem from the fact that she is a plant-human hybrid, the anthropocentric ideology of the comic is never interrogated. The morals of the original Black Orchid are without question grounded in a liberal humanist ethos.
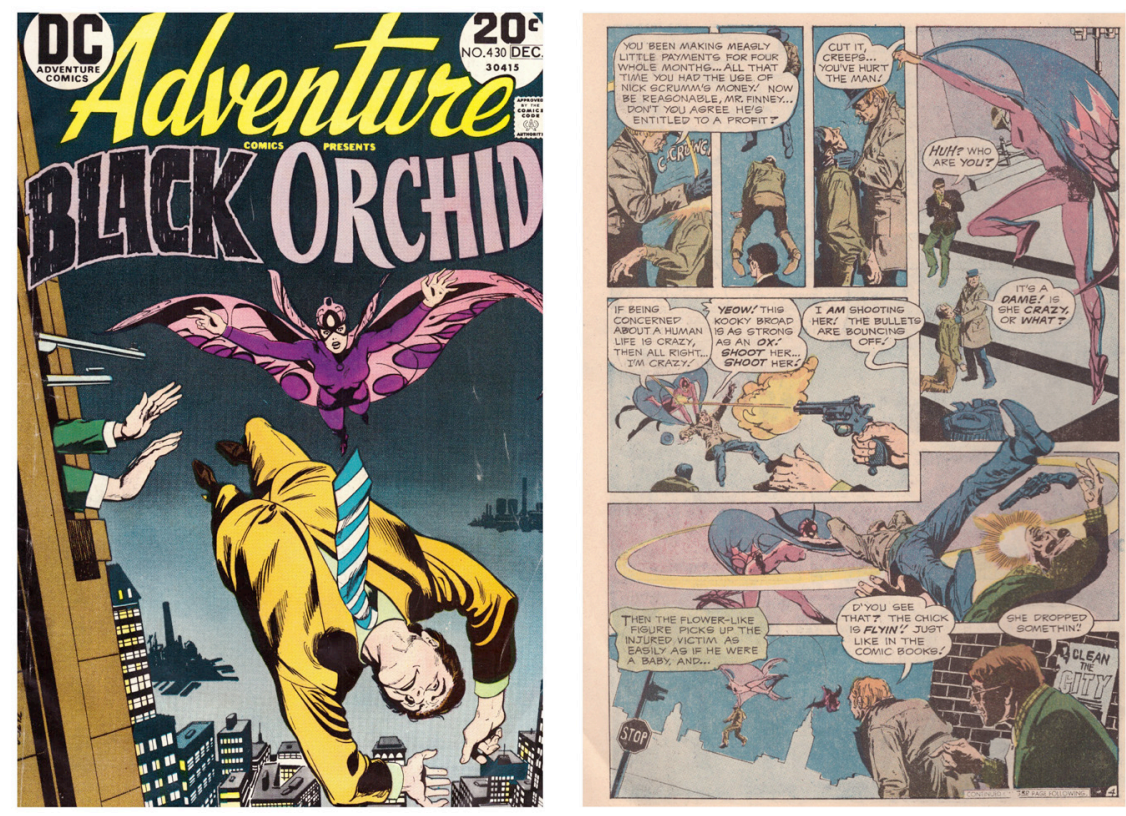
In 1988, Black Orchid was rebooted by Neil Gaiman and Dave McKean, on commission by DC editor Karen Berger. Gaiman and McKean wrote three issues, later to be collected in trade paperback under the Vertigo imprint, and Black Orchid was picked up as a single title that ran for 20 issues in the early 1990 s. The Vertigo Black Orchid is closely aligned to the deconstructive aesthetics of the 1990s revisionary style of superhero comics; self-referring and metafictional it strongly focuses on the processes of narration and creating storyworlds.1
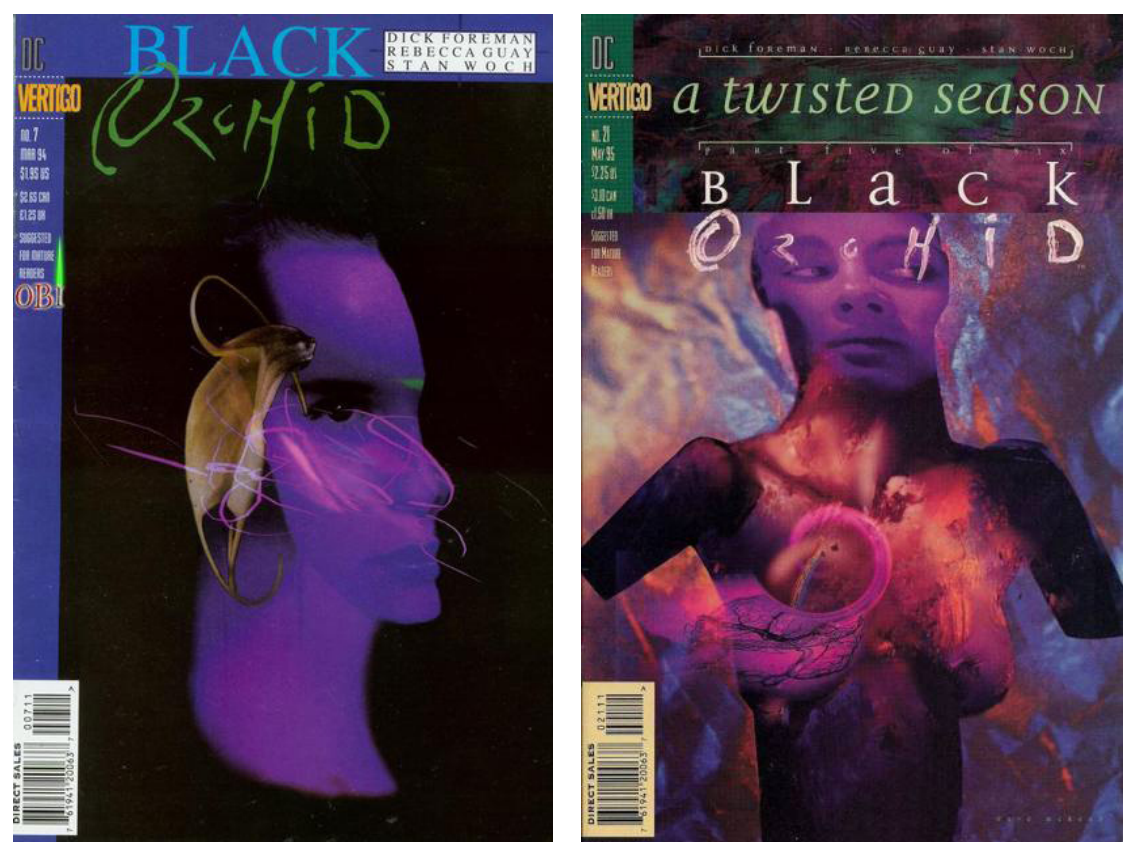

With the recent all over reboot of the DC timeline, the so-called New 52, Black Orchid has been grouped together with the occult Justice League Dark, headed by John Constantine. Here Black Orchid once again seems returned to a more conventional superhero identity.

1 For a discussion on revisionary superhero comics and deconstructive aesthetics, see Geoff Klock, How to Read Superhero Comics and Why (New York: Continuum, 2002) 

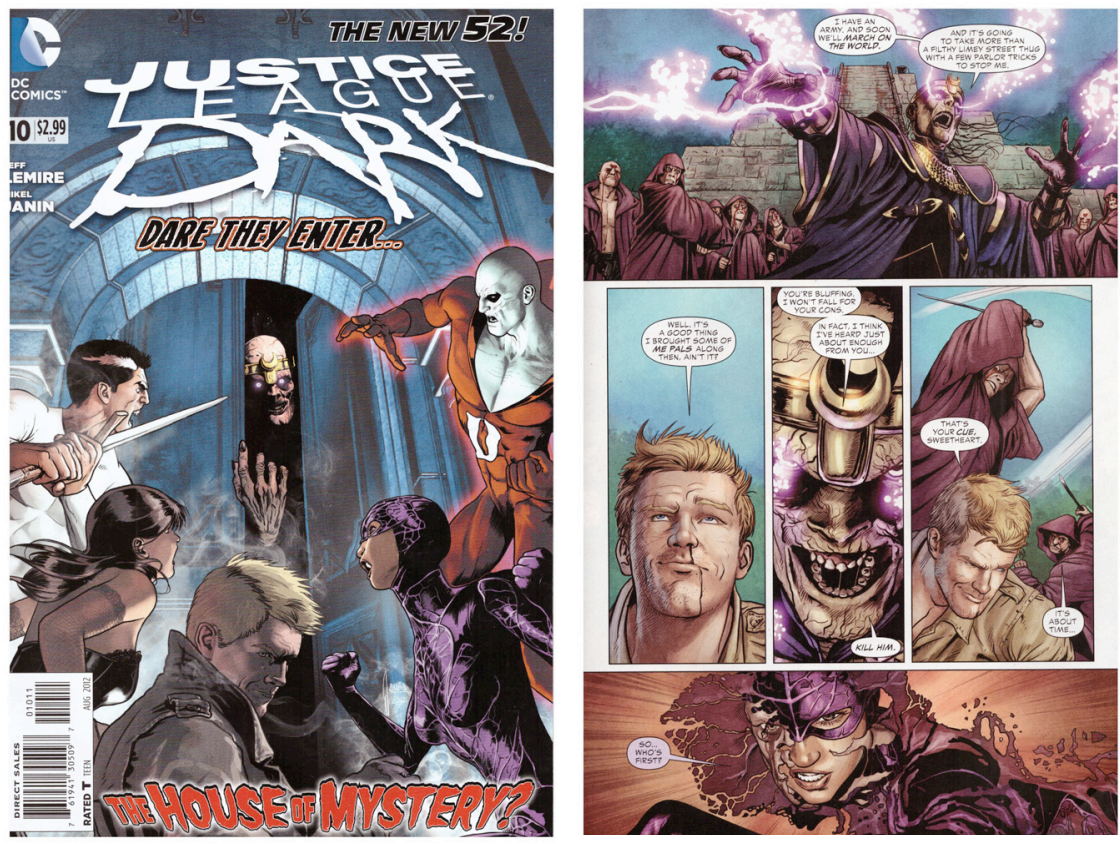

Framing the superhero genre as a media ecology, the 1988 reboot of Black Orchid could be described as an event of cybernetic feedback, where a new organization is configured from an already existing cultural environment, while at the same time reconfiguring that environment. Here, Gaiman and McKean explicitly thematize the fluid identity of the character Black Orchid, making the plant-human hybridity a central tenet of the narrative. In the reboot, the memory and personality of the character Black Orchid is not a transcendental unit that could be transferred from one version of the character to another, but rather it is grounded in a material environment. From a metanarrative position, Gaiman and McKean's Black Orchid comments on the reboot logic of the superhero genre, in which superhero characters are adapted to new cultural environments in order to generate new viable commodities.

Thus, the event of configuration is a prominent feature in the 1988 reboot of Black Orchid. But, as we shall see, the reading of the comic book Black Orchid also focuses on material configu- 
ration. The reading situation here becomes an embodied practice, not only a matter of interpreting, as an autonomous and disinterested subject, a foreign body of information, but also a matter of embodying the perceptions and experiences produced by the material properties of the comic book. And while it certainly could (and perhaps should) be argued that every form of reading, to some extent, is an embodied practice, it is nevertheless the case that the aesthetics and the reading practice of the comic book - in which movement and touch play an important part - explicitly stresses sensation as an emergent property. Accordingly, and following N. Katherine Hayles, it could be argued that the embodied perception - and consequently the meaning production - of Black Orchid hinges on the materiality of a given situation: it is cognition situated in the material.2 It is in this fashion that the reading of Black Orchid comprises a posthumanist experience.

In her latest book, Staying with the Trouble: Making Kin in the Cthuluscene, Donna Haraway proposes the concept of sympoiesis as a model for describing the emergence of embodied experience, comporting with her earlier theories of feminist-cyborg subjectivity, situated cognition and the becoming-with of companion-species. Haraway writes:

'Sympoiesis is a simple word; it means 'making-with.' Nothing makes itself; nothing is really autopoietic or self-organizing. In the words of the Inupiat computer 'world game,' earthlings are never alone. That is the radical implication of sympoiesis. Sympoiesis is a word proper to complex, dynamic, responsive, situated, historical systems. It is a word for wordling-with, in company."3

2 "In contrast to the body, embodiment is contextual, enmeshed within the specifics of place, time, physiology, and culture, which together compose enactment. Embodiment never coincides exactly with 'the body', however that normalized concept is understood. Whereas the body is an idealized form that gestures toward a Platonic reality, embodiment is the specific instantiation generated from the noise of difference.", N. Katherine Hayles, How We Became Posthuman: Virtual Bodies in Cybernetics, Literature, and Informatics (Chicago: University of Chicago Press, 1999), p 196

3 Donna Haraway, Staying with the Trouble: Making Kin in the Cthuluscene (Durham: 
The theory of sympoiesis can be described as a neocybernetic and ecological interpretation of the theory of autopoiesis. Initially presented by Humberto Maturana and Francisco Valera in their co-authored study Autopoiesis: The Organization of the Living (1973), the theory of autopoiesis describes how not just informational systems but even living systems, function cybernetically.4 According to the theory of autopoiesis, living organisms are operationally closed, and relate to the environment in which they are enmeshed as an observing system. However, the environment - and an external, objectively existing world - does not pre-exist an observing system, observation rather comes about following a set of interactive processes determined by the organization of the system. Thus, the theory of autopoiesis stresses perception as an act of creation. But while the perceptual apparatus is organized in relation to an environment, this relation is altogether internal to the observing system and determined by that system's own organization. Paradoxically, then, it would seem that the organization of living systems determines the environment, while at the same time being open to feedback from that very same environment. By creating their environments, organisms are created by the environment.

From a neocybernetic perspective, Mark Hansen has described this paradoxical environmental feedback as a system-environment hybrid.5 In neocybernetic systems-theories the relation between systems and environments is generally situated in the function of organizational closure. Thus, these theories argue that one should understand autonomy as a system that is structurally coupled to an environment, and with other systems, by way of organizational closure. Accordingly, reading the comic book spread of Black Orchid is, from a neocybernetic point of view,

\footnotetext{
Duke University Press, 2016), p 58

4 Humberto R. Maturana and Francisco J. Varela, Autopoiesis and cognition: the realization of the living (Dordrecht: Reidel, 1973), Originally published in Chile as De Maquinas y Seres Vivos, in 1972

5 Mark B. N. Hansen, "System-environment hybrids", in (eds.) Bruce Clarke \& Mark D. Hansen Emergence and Embodiment, New Essays on Second-order Systems Theory (Durham \& London: Duke University Press, 2009), p 115
} 
an emerging event, where the subjectivity generated hinges on a self-regulating and self-observing system that in turn prescribes the conditions under which the material environment (that is the comic book, as well as reader, movements of body and pages, and so forth) comes into being. Once coupled to the comic book spread, reader and comic book alike become part of a systemenvironment hybrid. It is the sympoiesis of system-environment hybrids, this co-production of perception that I wish to highlight in the following. This is how Black Orchid creates world.

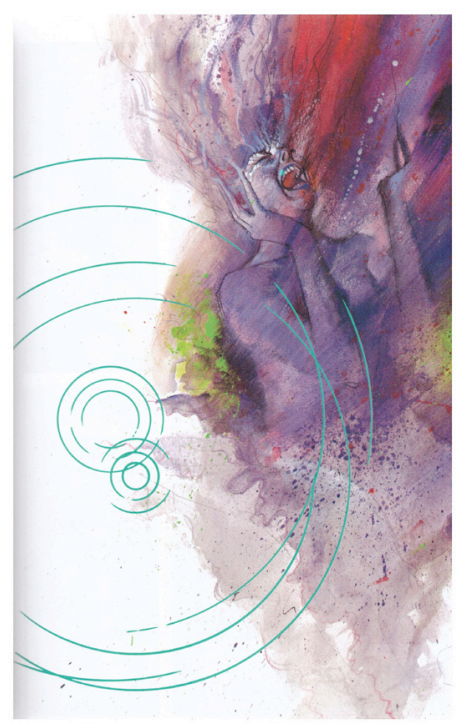

The opening sequence of Gaiman and McKean's Black Orchid culminates with a scream. It is, since we are dealing with the comic book medium, by necessity a silent scream. This silence is also stressed by the absence of captions. However, the strong presence of sound and the voice as a medium, even if it is only alluded to in the negative, points to the manner in which the narration establishes itself as a series of complex sensory events. These events, understood as system-environment hybrids, invite reader participation and sympoietic configuration by producing the embodied experience of reading. Text and reader are implicated in the plant-human hybridity of the Black Orchid character: in essence both text and reader are taking part in the becoming of a hybrid identity. As we shall see, reading Black Orchid here becomes a matter of participating in the memory process of a distributed subjectivity.

Some pages earlier in the opening sequence, the crime fighting Black Orchid has been murdered by the crime syndicate she is infiltrating. The scream, in a spread that leads up to a single image occupying a whole page, marks the rebirth of one of Black 
Orchid's plant-human hybrid bodies, stored and cultivated in a green house on the outskirts of the vast urban sprawl of Metropolis. Subsequently, the plot of Gaiman and McKean's reboot

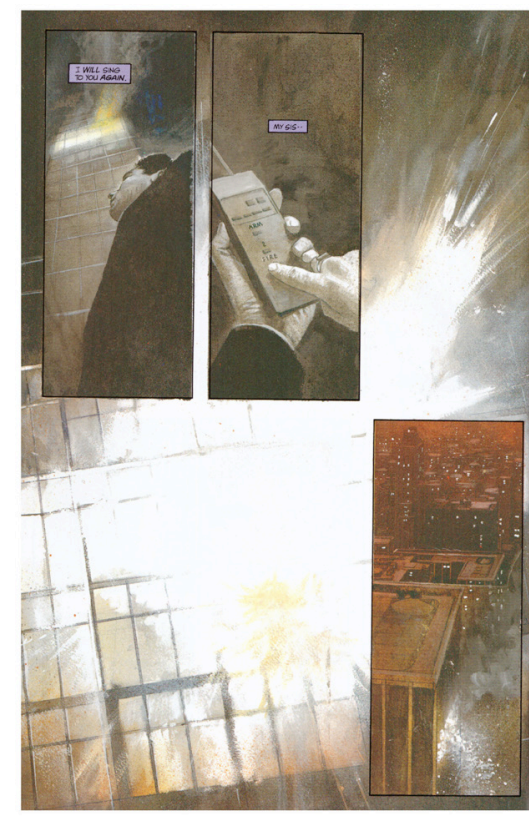
focuses on the emergent identity of the reborn version (or rather versions, as it soon becomes apparent that another, younger version also has been reborn) of Black Orchid. On the one hand, it would seem that each discrete plant-human body is the same as the other, sharing not only DNA but also a materially stored memory and a personality of sorts. On the other hand, the reborn Black Orchid has only a vague recollection of the experiences of her previous version, and a large part of the narrative of Black Orchid is devoted to - in the manner of a private investigator - collecting clues and tying together pieces of information into a coherent story. To this end, Black Orchid visits sites and characters well known to the reader of DC comics, questioning denizens of Arkham Asylum, such as the plant-based super-villain Poison Ivy, as well as receiving advice from Batman, before finally meeting up with Swamp Thing in the Louisiana Bayou. Here, in the "green" which is the living world-body of Swamp Thing, and which encompasses all living plants on Earth, Black Orchid learns about her past. As Swamp Thing traces the memories stored in her "cell spirals", Black Orchid - and the reader of course - learns, that she is the product of an experimental merging of the RNA and DNA taken from a woman called Susan Linden with the genetic material of various orchids. She also learns that the botanist in charge of the process, Philip Sylvain, apparently had been secretly in love with Susan. After her gangster ex-husband Carl Thorne had murde- 

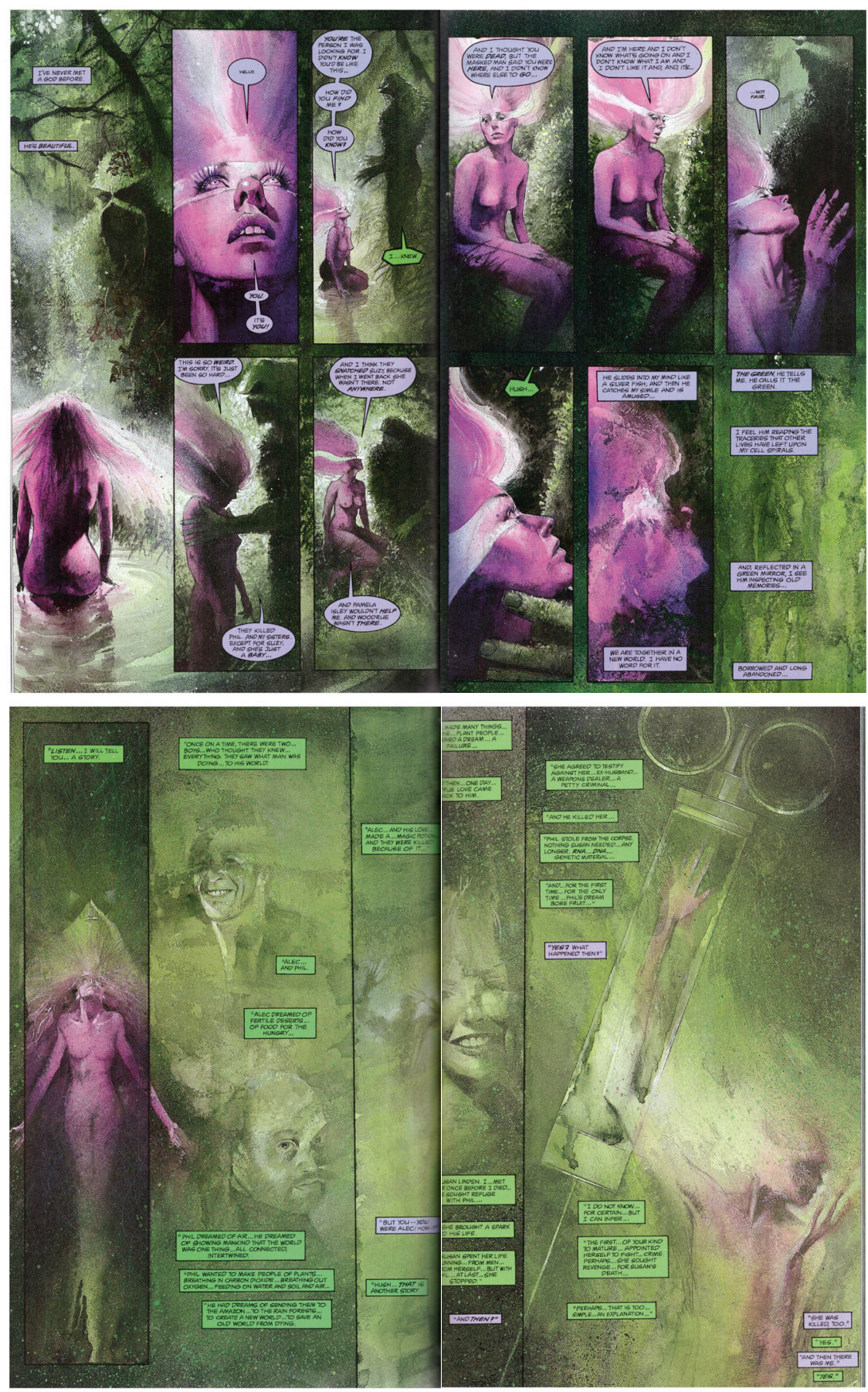
red Susan - she was about to testify in a trial against him - Philip seems to have taken the opportunity to satiate two of his most pressing urges in life, an erotic desire towards Susan and a desire to create plant people.

The appearance of Swamp Thing clearly illustrates, both on a visual and a thematic level, the emergence of a system-environment hybrid. Rebooted by Alan Moore in 1982 - also under editor Karen Berger - Swamp Thing, created by Len Wein and Bernie Wrightson in 1971, had been transformed from an enlightened and humanist environmentalist superhero, defending the "green" from the ravages of industrialized modernity, into a posthumanist, ecocritical creature not only defending but essentially being and embodying the "green". In the original 1971 version of Swamp Thing an experiment gone wrong turned the young scientist Alec Holland into the monstrous plant-being Swamp Thing. In other words, the original comic book Swamp Thing featured a human become plant, but essentially still with a human psyche and personality. Moore's reboot tips the ontology of Swamp Thing on its head. No longer a human transformed into a plant; in Moore's version, it is the swamp itself that has absorbed the body and memories of Alec Holland. A plant has absorbed the human, but is still essentially thinking and behaving as a plant (however that might be). Closely aligning their version of Black Orchid to Moore's Swamp Thing, Gaiman and McKean cast the narrative in a similar, posthumanist and ecocritical mould. But looking at the actual sequence in which Swamp Thing presents himself to Black Orchid, it is also clear that this emergent and environmentally grounded identity is situated in the material properties of the comic book. And perhaps more importantly, in the manner in which the comic book spread, by subverting and transgressing the distinctions between narrative units, emphasizes perception as an event of configuration, in which both reader and comic book alike participate. This is most clear in how the sequence organizes the panels and the gutters between the panels, eventually overthrowing the relation between background and foreground. 
The first page of the sequence, in which Black Orchid is slowly awakening after crashing into the Louisiana Bayou, enacts the emergence of a grid structure, materially emphasizing the return

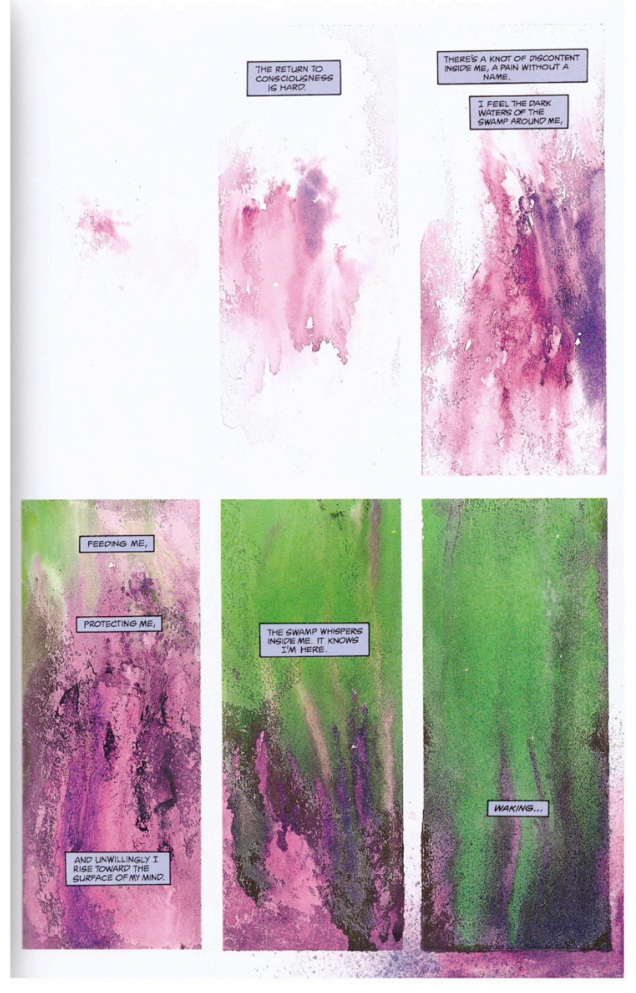

to consciousness and an ordered reality. In a sense, the wakening of Black Orchid coincides with the organizational structure of the medium. In the following spread, this grid structure, in which the gutters between panels have a predominantly sequential function, establishing a reading dominated by temporal progression and movement, is both enforced and countered. The spread is framed on two sides by the faces of Black Orchid and Swamp Thing, respectively, effectuating a circular movement, enfolding the reader within the environment of the medium, within the expanse of the spread. This spatial effect marks a site of perception where the presence of the aesthetic experience - of the world generated by the comic book medium as a system-environment hybrid - transpires in the present tense, while at the same time being imbued with temporal progression by the four panels framed in the spread. The four panels here function both as a structural grid, transforming the background into gutter, while simultaneously focusing the passage of that very same background into foreground. This oscillation between different temporalities as well as that between background and foreground, and between the materiality of the medium and the mediated content, further stresses the medium as a system-en- 

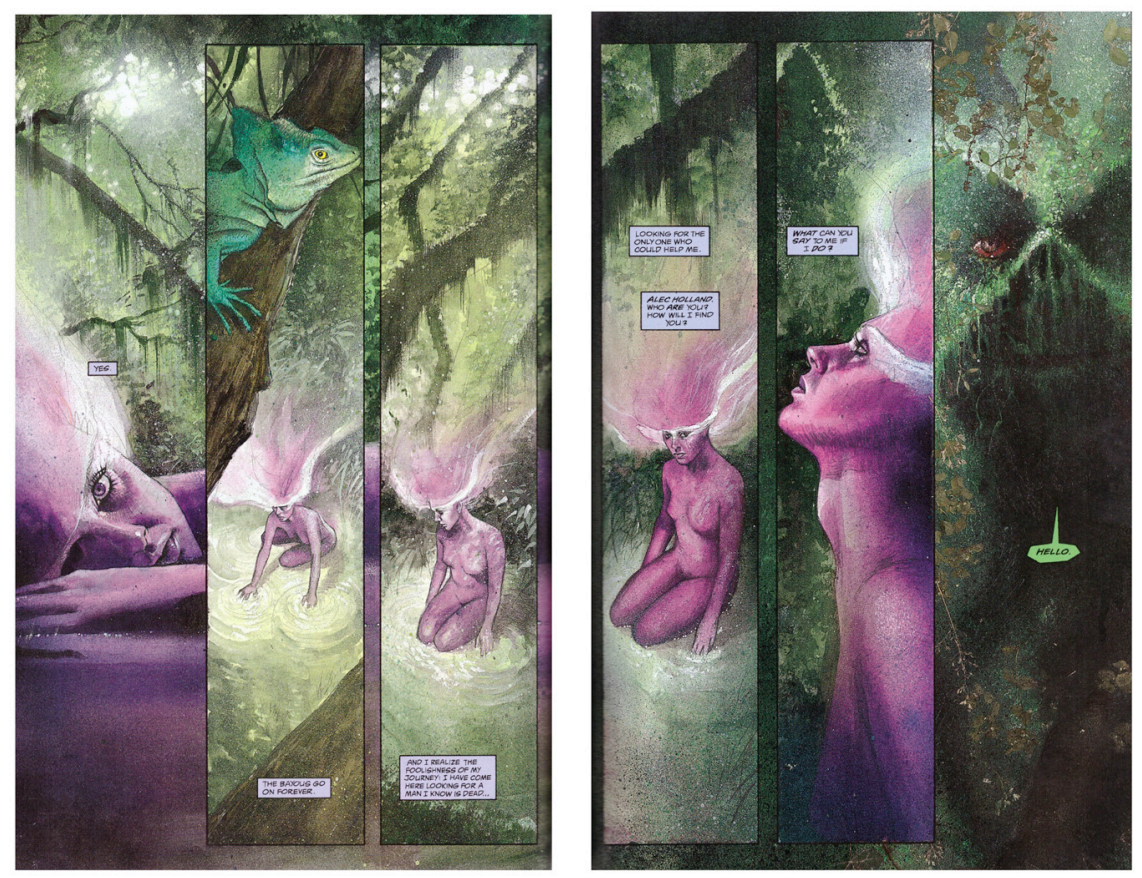

vironment hybrid.6 The circular movement of the spread, which clearly indicates the position of the reader, also emphasizes an embodied experience. In fact, the spread of a comic book presupposes a body holding it, and in that sense delineating an actual circular space. And as the distinctions between background and foreground, between mediating materiality and mediated content, evidently are permeable throughout the spread, there is nothing to say that this permeability would not extend to the body of the reader as well.

But it is not only the adaptation of Moore's rebooted and posthumanist Swamp Thing that sets Black Orchid out as a metafictional and deconstructive comic book. The event of killing the main character at the very beginning of the story also clearly functions both as an intertextual comment on the reboot logic

6 Timothy Morton discusses the tendency to point to the environment of the medium as the medial function of ecomimesis, a concept that has clear affinities with a sympoietic approach to aesthetic experience. See Timothy Morton, Ecology without nature: rethinking environmental aesthetics (Cambridge, Mass.: Harvard University Press, 2007), p $36 f$ 
- in self-conscious dialogue with the participatory culture surrounding the comic book industry - while at the same time establishing a link between the media ecology of the genre and the ecological identity of superheroes in general, and Black Orchid in particular. Memory here also becomes generic: the cultural memory of the superhero genre.

The initial death of Black Orchid is framed by a further insistence on voice as a creative medium. In the dramatic last frames leading up to her death, Black Orchid alludes to the activity of singing, as she makes a prophetic claim: "I will sing to you again. My sis...", before being interrupted, mid-sentence. The brusque silence enforced upon the song comes in the form of an explosion, ripping not only the word "sister" apart, but also transgressing levels between panels, gutters and page layouts. The blast

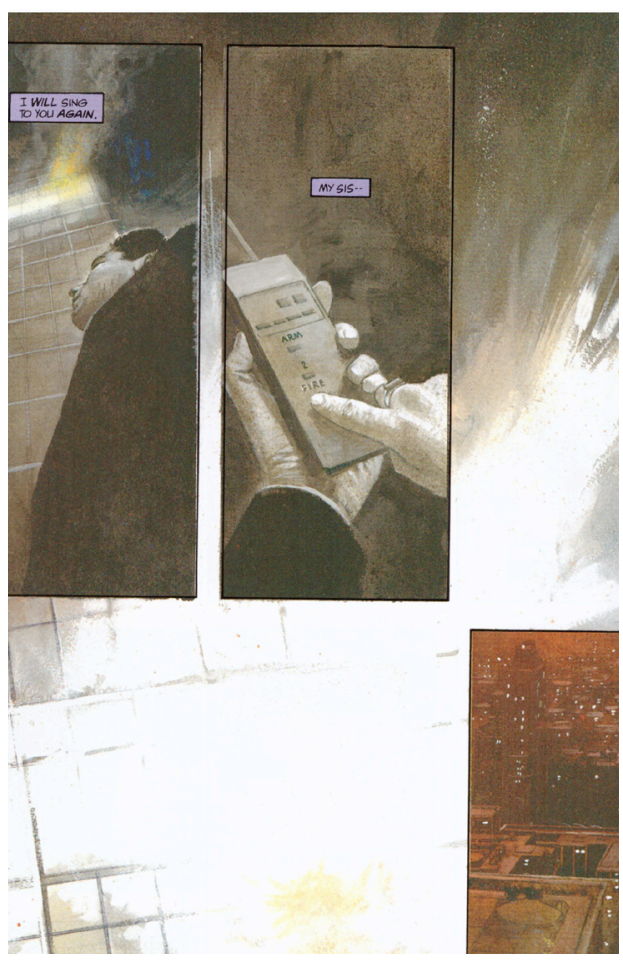
effaces the differentiations of the page that produce meaning, returning it to the supposedly empty whiteness of non-signification. At the same time the temporal progression produced by the succession of panels is broken, retrospectively, when the gutter between the two initial panels is transformed from a material component of the medium, into a site of representation. What was initially read as only the passing of time proves to be an anachronistic intrusion, a breakthrough of a time not yet arrived at. 
The silent explosion is then once again extended into the temporal passage of the white grid of the gutter, as the narration panels from the urban center out into the suburbs and finally lands in the green of the green house. In the following spread,
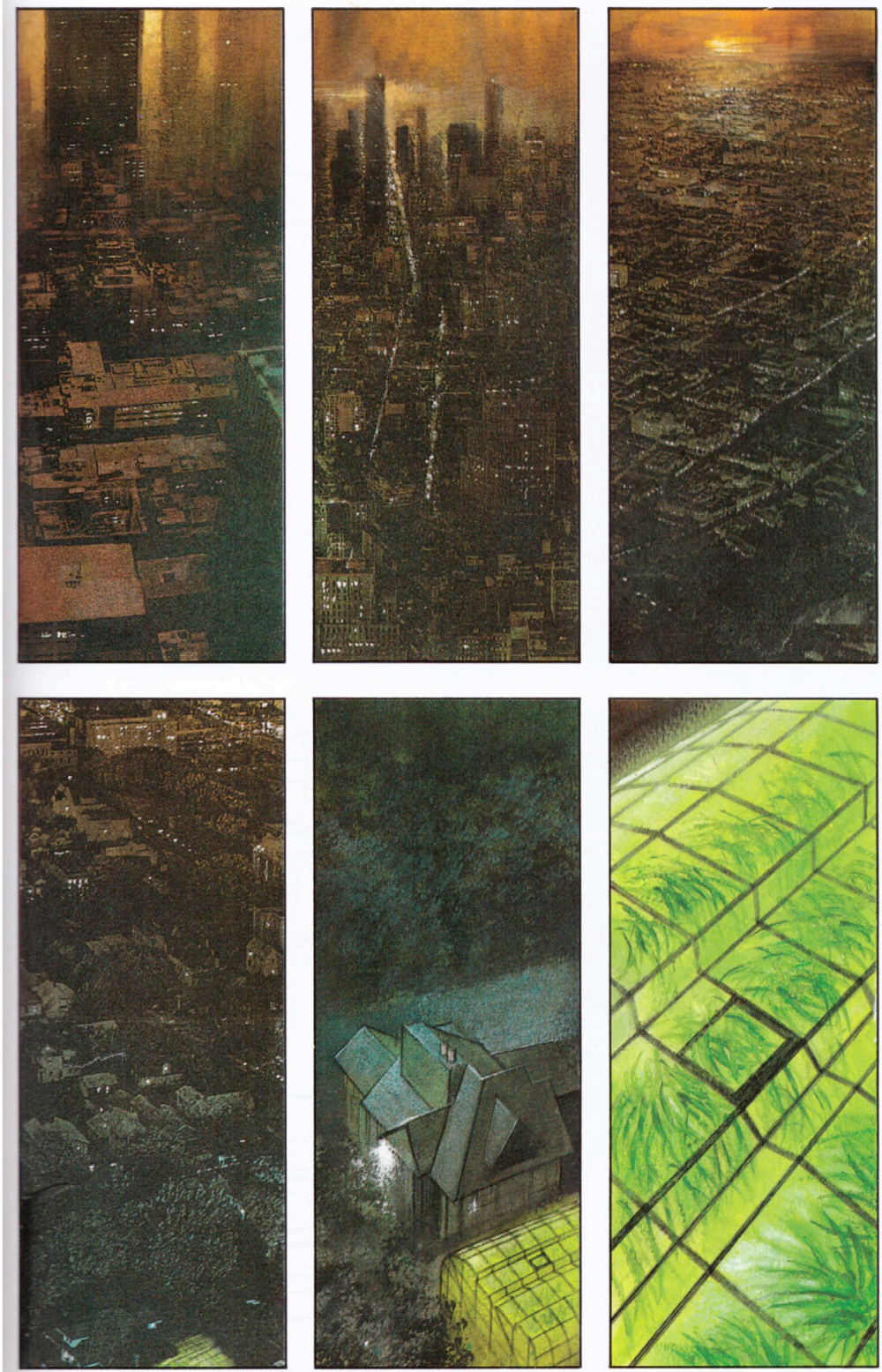
the gutter is extended into panel, and by the appearance of ripples initially attributed the leaking faucet, its temporal function is further enhanced by the temporality of the dripping water, while at the time imbuing this temporal passage with motion and sound. As the sequence progresses the meaning-producing unit of the water ripple is supplemented by the iconography of sound waves, producing an increasingly complex sensorium that culminates in the sudden and violent birth of the new Black Orchid.

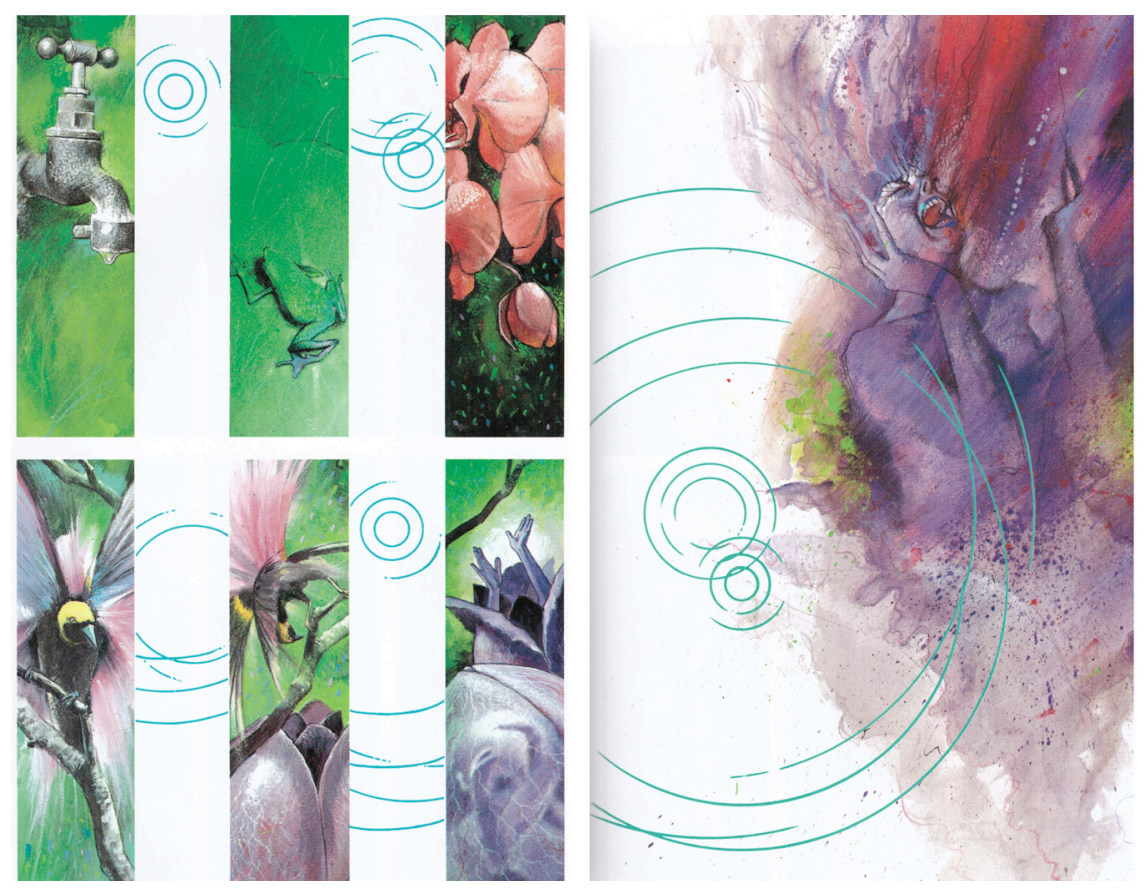

The emergence of the new Black Orchid could here be understood as the emergence of a system-environment hybrid. The becoming of the new body explicitly evokes the materiality of the environment of the medium, in a process delineating and simultaneously producing the senses of the reader. The dropping water of the faucet here translates into the indistinct fluidity of the remediated splash of watercolors from which the silent scream takes form. 
The gutter is a space of utmost importance in the production of meaning in the language of comic books. The gutter is essential in producing temporal succession, and commands the reader to
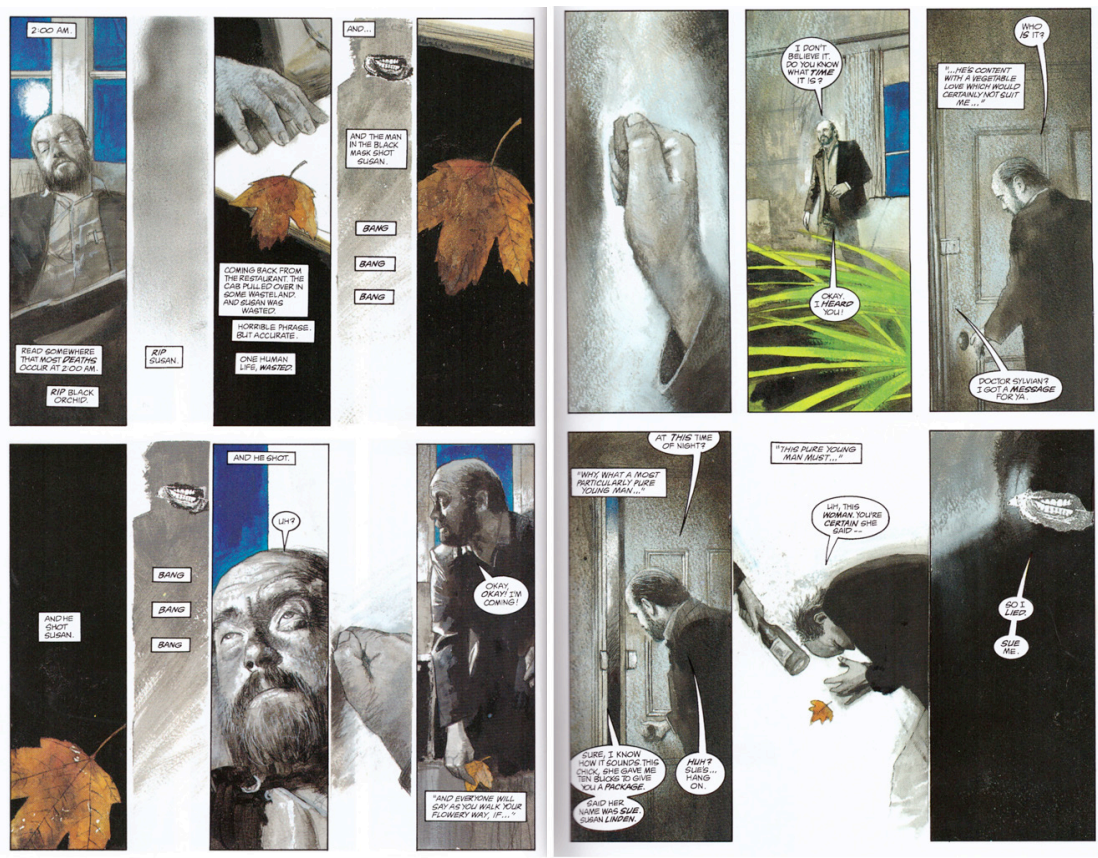

initiate sequential coupling. Here, however, its characteristics are modified. Instead of merely being a space marking the temporality and progression of the reading, functioning as a site where the reader, as an autonomous and disinterested subject, binds together the different units of information provided by the panels into a coherent narrative, the space of the gutter is invaded by residual information.

Emphasizing the feedback between the systemic organization of narrative meaning and the environment of the medium, the sequence becomes an embodied system-environment hybrid. This effect is reached partly by material properties of the medium. It is clear that in this sequence, the medium of the comic book is made into an active participant in the production of 
meaning. The very act of reading, and the bodily movements and sensations that act involves - seeing, touching, hearing - is highlighted.

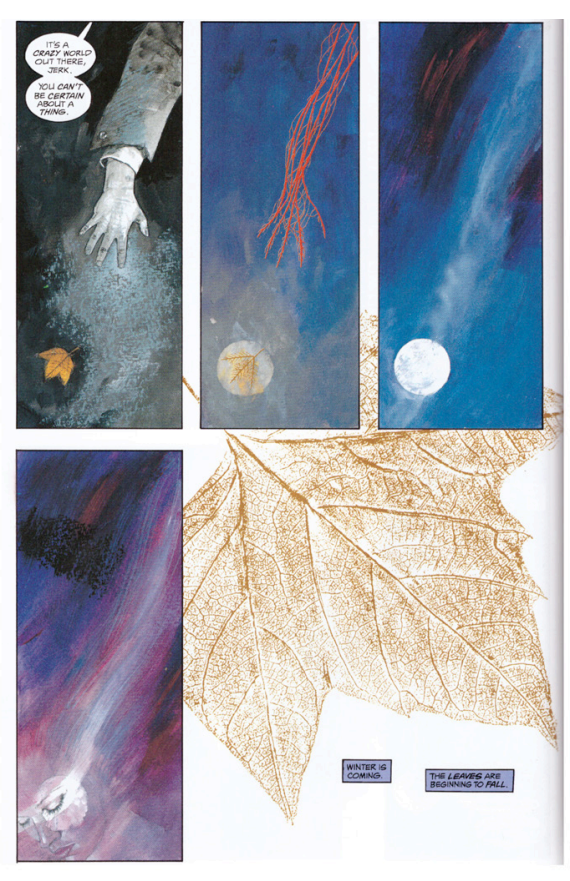

The third sequence I will look at opens in the home of Philip Sylvain. Once again, the gutter is invaded by residual information, producing an afterimage, that only in retrospect is put into context. The invasion of the gutter is paralleled by the invasion of the character Carl Thorne into Philip's home. Carl has recently been released from prison. His appearance coincides with the telling, through the memory of Philip, of the creation of the first Black Orchid hybrid life form. As Carl bludgeons Philip unconscious, the narration dissolves, and the identity of the new Black Orchid coalesces with the backstory of Philip and Susan. [Figure 16] Here the event of the reboot is put to the fore, enforcing configuration as systemenvironmental feedback. It is an event that presupposes uncertainty and openness. As Carl states: "You can't be certain about a thing." Several movements are generated between the four panels and the background. The iconic similarities enfold the two identities of Black Orchid and Philip, juxtaposing the veins, arteries, and capillaries of Philip's arm with the vascular tissues of the dropped maple leaf. At the same time, they are connected by the moon, reflected in the first panel on the floor beside the hand, and in the fourth in Black Orchids visage, connecting the moon with her closed eyes, making the moon a point of entry for the spectator. The moon is further connected to the visual 
sense by the allusion to microscopic vision, produced by the large, transparent, leaf in the background.

While these different units of the page thus are related, they are nevertheless not connected in the form of a narrative. The chronological reading of the panels is here also countered by several lines of flight. The falling leaf in panel one suggests a movement in depth; the arm, the vascular system, the wisp of cloud, and Black Orchid's strangely flowing hair-like outgrowth, suggest an increasing acceleration (the leaf in the moon actually pointing) towards the upper right corner; while the leaf in the background emphatically accentuates unidirectional chronology. The page presents relation as movement and event, rather than structured meaning. This is where the first issue of Black Orchid (1988) ends.

The following sequence, in two spreads, which accordingly opens the second issue of Gaiman and McKean's three-issue reboot, traces the falling leaf, in a montage of juxtaposed bits of memory, belonging to the original Susan Linden, and thematizing voice and autobiographical narrative as something essentially estranged, in which Black Orchid is thinking thoughts not her own, talking to herself in the narrative third person "she has to - I have to get out of this city". The first page in the sequence situates the narrative in the voice and resting visage of Black Orchid. In the second spread, the temporalities of memory and personal history, as well as the different temporalities of the comic book reboot, undergo a

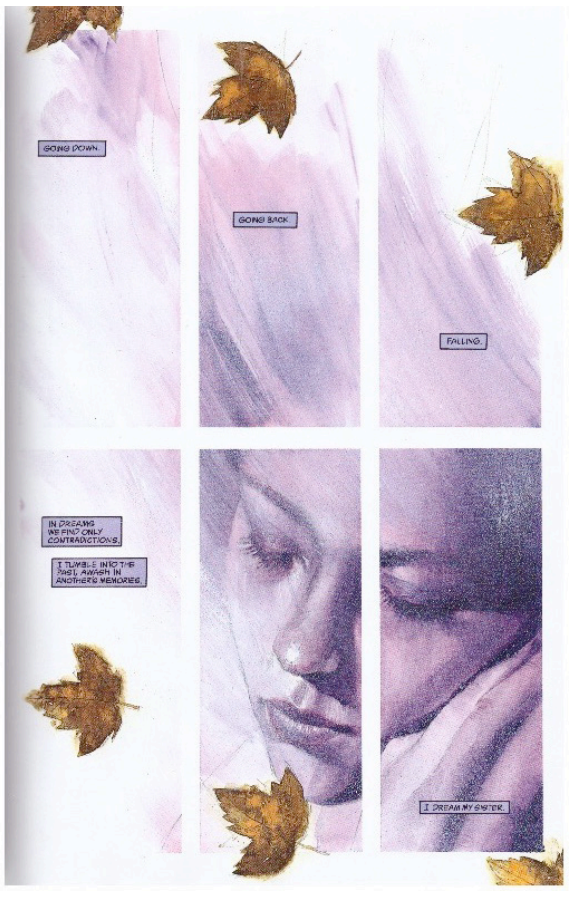


complex layering. The sequences between panels are contrasted to the descending movement of the leaf within the gutter, as well as juxtaposed to the temporalities represented within panels. Memory and identity here also become a question of material storage and material participation, perhaps most evident in the double helix of the DNA spiral, functioning as a hypericon, commenting on the vortex of system-environment feedback. Eventually, the narrative crumbles, the conflicting movements and temporalities take over and the panels dissipate, leaving the

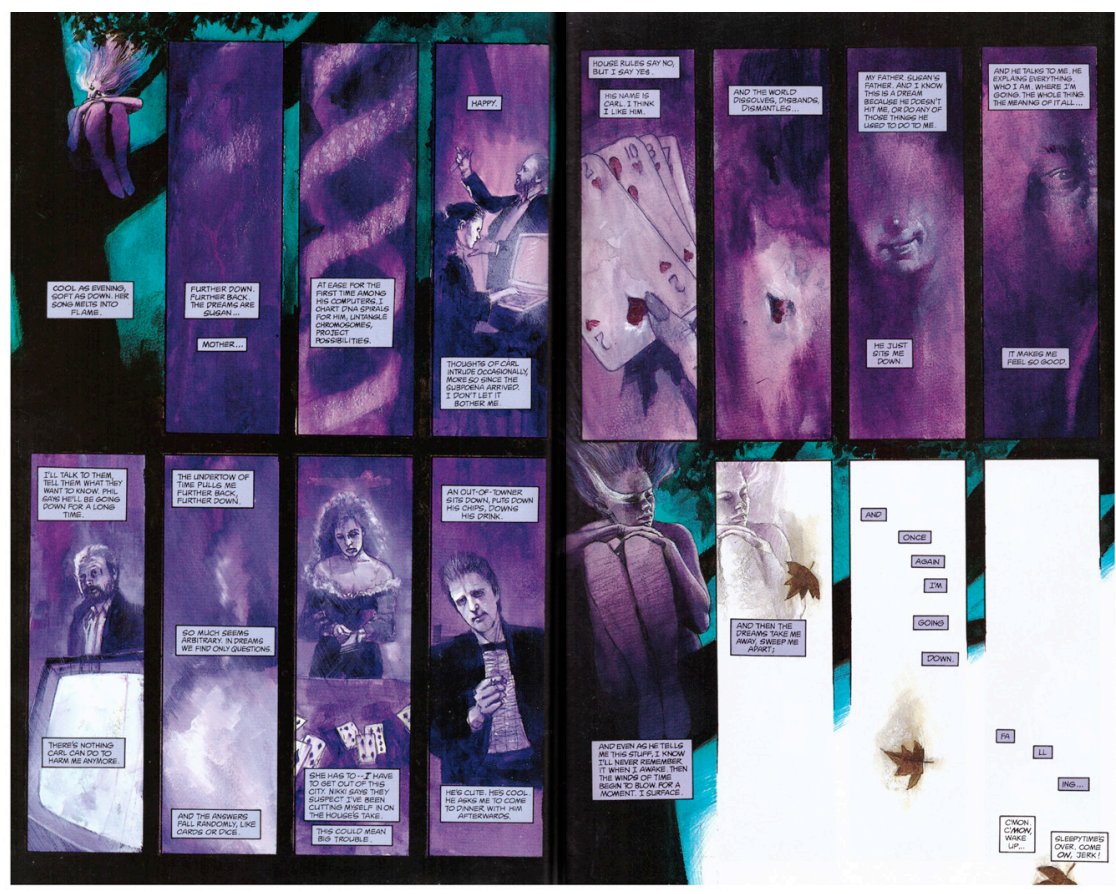

leaf to fall, accompanying the breaking of the last lines of the soliloquy, over the end of the page.

This is where Black Orchid insists on getting: outside the panel, beyond the page, into the green, where human-plant technoculture produces new experience, new cultural expression, and new installments in the ever-expanding franchise of superhero comics. 
Significantly, however, one finds that this is the point - on the precipice of new experience, on the verge of falling outside the frame - at which the voice of the antagonist Carl Thorne calls us back to consciousness, in a rather rude Althusserian interpellation: "Sleepytime's over. Come on, jerk!" Reminding us that the sympoiesis of superheroes is always set within the context of a very real power struggle, where the materiality of the medium is a site for emergent subjectivities, while always already representing the commodification of lived experience.

Reminding us also that the participatory aesthetics of the comic book Black Orchid is about command and control as much as it is about the co-production of ecological creativity.

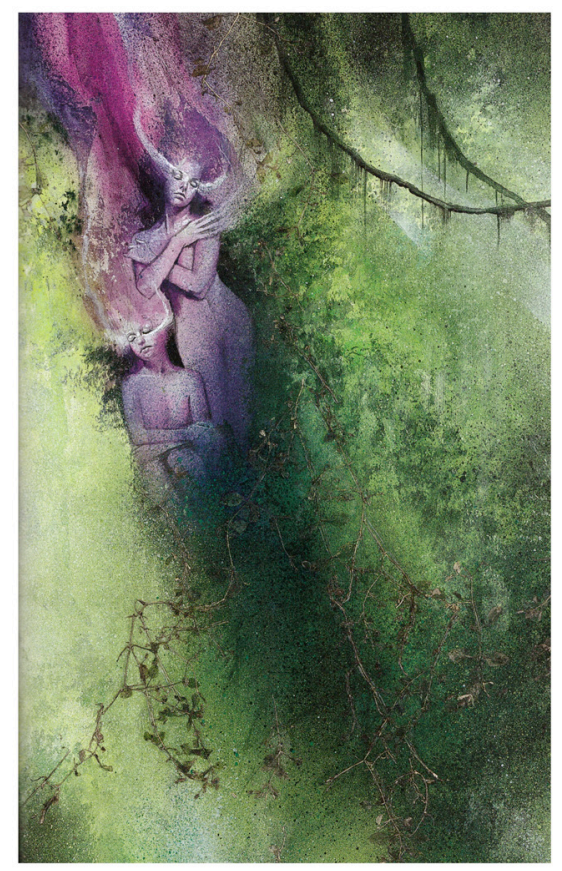

The becoming-with of sympoiesis, following Haraway's argument, emerges here as a model for making worlds - for "wordling" - and for a material semiotics, where matters matter, and meaning, as well as embodied identities, emerge in the form of systemenvironment hybrids. Through the concept of sympoiesis, the agency of material things can supplement the meaningoriented focus of traditional, modernist literary studies, perhaps offering a viable, and ecologically sustainable, trajectory for non-exclusive humanities: non-humanist (and in this sense posthumanist) humanities. Black Orchids in the green of the living. 


\section{Hvorfor notationel ikonicitet er en form for operationel ikonicitet}

\section{Sybille Krämer}

\section{Det fonografiske dogme}

Hvad betyder 'inskription'? Få spørgsmål forekommer lettere at besvare: en inskription er sprog, som er blevet nedskrevet. Den holder det talte ords flygtighed på afstand og befrier kommunikation fra talens ansigt-til-ansigt-forankring. Det skrevne ord overfører den akustiske sekvens til en visuel konfiguration; det udvider kommunikationen over afstande i tid og rum. At forvandle det talte til det skrevne muliggør ligeledes kontrol, rettelser og kritik, ligesom det åbner for spredning og arkivering af det der kommunikeres som tekst.

Det var nøjagtig debatten omkring 'mundtlighed og skriftlighed' (Goody 1968, 1986; Havelock 1976, 1986; Ong 1982)1 i den sidste tredjedel af det forgangne århundrede, som afdækkede skriftens kreativitet og hævede det skrevne ord til det samme niveau som det talte. Siden da er det talte og det skrevne ord blevet betragtet som to forskellige former for sprog, hver med sin egen 'performance profil' i relation til deres mediale, sprog-

1 Se også Finnegan 1973; Falck 1990. Overordnet om debatten: Krämer 200 5a. 
lige, og kulturelantropologiske karakter (Echlich 1994; Koch/ Oesterreicher 1985, 1994; Olson 1991; Parry 1971; Raible 1991, 1993; Zumthor 1984).

På trods af denne genopdagelse af skriftlighed, er en traditionel antagelse - nærmest en vedtaget sandhed i debatten om skriftlighed - forblevet uudfordret: Troen på skriftens sproglignende karakter. I forbindelse med den almindelige tvedeling mellem sprog og billede, placeres skriften udelukkende inden for sprogets felt. Skrift fortolkes som en form for sprog og ikke som en form for billede. Den i mellemtiden klassiske håndbog Schrift und Schriftlichkeit. Writing and its use (Günther/Ludwig (red.) 1994), opsummerer udfaldet af skriftlighedsdebatten og definerer skrift som "den mængde af skriftlige tegn gennem hvilken et talt sprog optegnes" (Günther/Ludwig (red.) 1994: VIII.; Koch 2009: 58). Vi vil kalde det synspunkt at skrift først og fremmest er en fikseret version af et talt sprog for det fonografiske dogme (Krämer 2003b: 520).

\section{Tre blinde pletter ved et tale-centreret skriftbegreb:}

Det er muligt at afdække tre blinde pletter ved det tale-orienterede skriftbegreb:

(1) Antagelsen at skrift refererer til tale:

Det antikke græske alfabet understøttede aldrig teorien om at alfabetet udelukkende refererer til talens lyde, for vi ved i dag at de græske bogstaver ikke kun refererede til ord men også til tal og til musikalske toner (Kittler 2003: 198-200; Ernst/Kittler (red.) 2006). Eller tænk på opfindelsen af moderne, symbolsk algebra, hvis konstituerende tegn består af alfabetiske bogstaver, som hverken refererer til talens lyd eller til tal, men snarere til strukturelle former i almenhed. Desuden er alfabetets succes også forankret $\mathrm{i}$ tegnenes organisatoriske potentiale, ${ }^{2}$ som har vist sig at være det ideelle instrument til at opnå en præcis sortering af alle typer af lister, ordbøger, telefonbøger osv. (Günther

\footnotetext{
2 O.A. I originalen skriver Krämer her om de " 26 tegns organisatoriske potentiale", men da dette antal dels skurrer i den skandinaviske læsers ører, og Krämers pointe desuden relaterer sig til den generelle alfabetiske organisering (som f.eks. også er gældende for det græske og det kyrilliske alfabet) og ikke specifikt til det latinske alfabet, har jeg valgt at udelade antallet i oversættelsen.
} 
1994). Eller overvej den sproglige funktion af tegn som punktummer, tankestreger, parenteser og operationelle tegn, som ikke har nogen ækvivalent i det talte sprog. Koreografi var også et vigtigt medium for udviklingen af moderne dans, ligesom musikalske noder har været vigtige for udviklingen af den vestlige verdens musik. Matematik og logik ville være utænkelige uden notationssystemer. Computeren ville være utænkelig uden programkode, ligesom digitalisering er forankret i det binære alfabet. Det er således tydeligt at skrift ikke er et sekundært system som refererer til det talte sprog som sit primære system. Snarere er det et enestående symbolsk system, som kun lejlighedsvis refererer til mundtlig tale.

(2) Antagelsen af linearitet som et strukturerende princip for skrift:

Teorien om skriftens linearitet er en anden problematisk, for ikke at sige fejlagtig, antagelse, som det tale-centrerede skriftbegreb fører med sig. Det talte ords fremdrift danner en tidslig rækkefølge, og det antages at denne endimensionelle følgestruktur overføres til den rumlige organisering af skrevne tegn. Linearitetsprincippet fra det talte sprog erklæres således også for skriften. Men selvom både det at skrive og det at læse er aktiviteter der udspiller sig i tid, så gør skriften altid brug af overfladens todimensionalitet, og dens samtidighed eller synkronisitet (Groß 1990: 236-238). I alle former for skrift - også fonetisk skrift - struktureres konfigurationen horisontalt, idet linjerne fortsætter mod enten højre eller venstre, så vel som vertikalt fra top til bund eller for nogle få undtagelsers vedkommende fra bund til top. Denne skriftens todimensionelle matrice har ingen ækvivalent i mundtlig tale; således er skriften tydeligvis ikke lineær (Harris 1990: 39).

(3) Reduktionen af skrift til den grundlæggende kommunikative funktion.

Når skriften nedfælder det talte ord, overtager den talens kommunikative funktion. Men skriften er desuden det ideelle værktøj, ikke alene til kommunikation som er udvidet i tid eller rum, men også til kognition. Skriften er en form for tankeredskab. Overvej for eksempel skrevne udregninger som gør det mu- 
ligt at løse regneproblemer gennem applikationen af algoritmer som arrangerer og omrokerer de skrevne symboler. Videnskabsfolks notesbøger og sågar romanforfatteres, viser ligeledes hvordan inskriptioner tjener som medium, der muliggør den gradvise udvikling af tanker og overbevisninger. Skrift fremmer således eksternaliseringen, selvobservationen og kontrollen af tænkning og kognition. Skriftens rum udgør et tankelaboratorium.

Ideen om at skrift er en form for sprog, og at den strukturelle organisering af skrift er afledt af den lineære organisering af talen, rammer således helt ved siden af. Men hvad er alternativet?

\section{At overvinde det fonografiske dogme}

I løbet af de seneste årtier er forskellige fremgangsmåder blevet udviklet til at overvinde det fonografiske dogme. Det er blevet kritiseret og stillet spørgsmål til på mange forskellige måder, hvoraf seks skal nævnes her:

(1) Ikke-alfabetisk og ikke-europæisk skrifts rolle som politisk magt-, organisations-, kommunikations- og tænkningsmiddel er blevet undersøgt (Jan Assmann 1992; Gong 2009; Wilcke 2000).

(2) Brugen af notation i naturvidenskaberne, matematikken og logikken er blevet studeret, hvilket har afdækket at videnskab ville være umulig uden visuelle markeringer som skrift, tabeller og diagrammer (Hoffmann 2010, 2008; Klein 2003; Mersch 2005; Rheinberger 1999).

(3) Inden for litteraturvidenskaben er skriftens scene og litteraturens grafiske dimension blevet studeret (Campe 1991; Giuriato/Kammer 2006; Giuriato/Stingelin 2008; Raible 2004; Stingelin 1999; Zanetti 2012), inden for musikvidenskab er forskning i notation og kladder blevet stadig vigtigere (Magnus 2011), og i dansevidenskab er fokus skiftet til koreografiens notationsformer (Brandstetter et al. 2010).

(4) Antikke kulturstudier og klassisk filologi har rekonstrueret både skriftlige dokumenters materialitet, som en særlig orden af virkelige genstande, og de praksisformer som afhænger af brugen af inskriptioner (Cancik-Kirschbaum 2005; Damerow 1993; Schmandt-Besserat 1992). 
(5) Computeren er blevet anerkendt som skriftmaskine, og skriftens rolle som basis for digitalisering og programmering på den ene side og internetkommunikation på den anden side er blevet diskuteret (Bolter 1991, 1997, 2005; Grube 2005).

(6) De ideografiske elementer i udviklingen af skriften er blevet understreget. Lad mig kort adressere dette vigtige aspekt af ideografien. I skriftlige kilder som går tilbage til det græske alfabet kan det observeres at de oprindeligt bestod af kæder af bogstaver som knap nok kunne dechifreres med mindre de blev læst som lyd. Over tid er grænserne mellem ord blevet markeret ved hjælp af mellemrum; tegnsætning, kapiteloverskrifter, afsnitsinddelinger, fodnoter osv. er også blevet introducerede for at gøre tekster lettere at læse og for at forstå deres syntaktiske og semantiske struktur. Dog har ingen af disse elementer ækvivalenter på det talte sprogs akustiske niveau. Disse aspekter er ikke fonetiske, men snarere ideografiske, og disse ideografiske aspekter repræsenterer ikke det talte sprog selv. Det er således tydeligt at selve udviklingen af alfabetisk skrift allerede tenderer mod at inkorporere dimensioner i sit skriftbillede, som er uafhængige af og neutrale i forhold til det talte sprog (Raible 1991, 2009; Krämer 2005).

For at opsummere indtil videre: det fonografiske dogme og skriftbegrebet som fokuserer på mundtlig tale er blevet kritiseret på mange måder. Alligevel er der aldrig blevet skabt en teoretisk konsolidering af disse forskellige tilgange eller en systematisk udvikling af et generelt, fonetisk neutralt skriftbegreb som sammenknytter alfabetiske og ikke-alfabetiske, matematiske, logiske, musikalske, koreografiske og digitale former for skrift. Det er præcis på dette punkt at begrebet 'notationel ikonicitet' er relevant, idet det definerer et perspektivskifte fra et taleorienteret til et taleuafhængigt skriftbegreb. Begrebet 'notationel ikonocitet' sigter på at tilvejebringe en kritisk revision af det fonografiske såvel som det alfabetcentrerede skriftbegreb. De følgende refleksioner forsøger at indramme dette anderledes skriftbegreb. ${ }^{3}$

3 Begrebet 'notationel ikonicitet' er introduceret i Krämer 2003, 2012, og undersøgt fra forskellige disciplinære perspektiver i Krämer/Giertler 2011 og Krämer 


\section{Notationel ikonicitet}

Begrebet 'notationel ikonicitet' sigter på at revidere det sprogafhængige skriftbegreb. En skreven tekst tæller ikke længere som 'rent' sprog, men som en hybrid mellem sprog og billede. Det afgørende punkt her er at skriftens specifikke potentiale - for så vidt som det rækker ud over kommunikation i tid og rum alene kan forstås fyldestgørende når vi betragter dets implicitte ikonicitet.

Talen om 'notationel ikonicitet' drejer sig om en form for ikonicitet som er iboende i næsten alle ${ }^{4}$ skrevne tekster og som baserer sig på det faktum at skrevne tekster er materielt og perceptionsmæssigt indskrevne $\mathrm{i}$ et todimensionelt rum, som de udnytter og som - uafhængigt af den primært lineære skrive- og læseproces - præsenterer sig visuelt overskueligt og simultant for deres betragter og læser. Det skrevne deler sine visuelle og todimensionelle attributter med almindelige billeder, men afviger alligevel fra disse - og forbinder sig til sproget ved at inkarnere en form for organiseret tegnsystem som er både distinkt og syntaktisk. I kraft af denne relation mellem det billedlige og det sproglige, skaber skriften et operationelt felt, som endnu ikke har et forbillede hverken i det billedlige eller i det sproglige: nemlig det grafiske mediums potentiale til at udforme og transformere tegnstrukturer kreativt og udforskende på måder som lader sig reproducere.

Dette er hvad vi ønsker at kalde for 'operativ ikonicitet'. Denne operativitet ${ }^{5}$ finder sted når skrivningen af tekster forvandler sig til et laboratorium for deres forfattere i udfoldelsen af deres egne tanker; hvor komponister komponerer musik med hjælp fra nodeblade; hvor matematiske problemer løses med papir og blyant, hvor en programmør konstruerer algorit-

et al. 2012.

4 Undtagelse: Braille osv.

5 OA: Selvom “operativitet” ikke er et gængst ord på dansk, har jeg valgt at benytte det som oversættelse af det engelske "operativity", frem for det umiddelbart lidt mere mundrette (men stadig let kluntede) "operationalitet" for at bevare Krämers skelnen mellem det engelske "operational" og "operative" og afledninger af disse, hvor "operativ" i min oversættelse beskriver et fænomens (skriftens) disponering for tænkning og handling, fx i løsningen af et matematisk problem, mens "operationel" mere overordnet kan beskrive den praktiske omsætning af et teoretisk begreb. 
merne til en kompleks operation som er læselig for maskiner, hvor et tryk på en knap på et computertastatur aktiverer et link som åbner et website. Det skrevne udtryk bliver et produktivt redskab og et undersøgelsesinstrument til at gøre noget, som ikke ville være muligt eller i hvert fald ville være meget vanskeligt at udføre uden. Det skrevne ord repræsenterer altså ikke bare noget, det skaber også det repræsenterede - i større eller mindre grad.

Almindeligvis bruger vi visualitet til at definere ikonicitet. Men - og dette er omdrejningspunktet i vores argumentation - det er ikke bare skrifttegnenes visualitet, men i stedet deres spatialitet som har betydning i denne sammenhæng. Et tredimensionelt rum omgiver os. Men skrevne tekster trækker på en anden form for rumlighed: det todimensionelle rum. Billeder står således i kontrast til skulptur og arkitektur: de er flade. De deler denne fladhed med andre visuelle artefakter såsom grafer, diagrammer, kort - og skrift. Opfindelsen af 'kunstig fladhed' 6 transformerer overfladen på en hvilken som helst fyldig gestalt til en 'overfalde uden dybde', som kun er vigtig i kraft af hvad som er indskrevet på den. Fra hulemalerier og tatoveringer, over bemalede lærreder og trykte sider, til computerskærmen og smartphonen kan vi efterspore et kulturelt fænomen: Håndteringen af flader dækket med billeder, tegn og beskrivelser. Der eksisterer en "udfladningens" kulturteknik (Krämer 2014: 6) som udgør en vigtig streng i vores medieudvikling. Dens relevans er åbenbar: vores livsverden er altid situeret i et rum som relaterer sig til et bagved eller et under, som er skjult for vores blik, og det er denne usynlige og ukontrollerbare dimension som ophæves af kunstig fladhed. Hvis noget projiceres og indskrives på en overflade bliver betragteren og læseren omflyttet til at indtage et fugleperspektiv: et rum opstår som er fuldstændig kontrollerbart og - i det tilfælde at det har en begrænset udstrækning - umiddelbart kan transporteres. Resultatet er samtidighed og overblik, det vigtige potentiale ved den kommunikative og kognitive organisering.

6 Vedrørende fladhed som et medium for det billedlige, se Summers 2003. 


\section{Spatialitet}

Det bliver nu tydeligt hvorfor det fonografiske skriftbegreb er for snævert. Så længe forholdet mellem et talt og et skrevet sprog betragtes som et oversættelsesforhold er skriften underlagt sekventialitetens regime. Den akustiske lydsekvens overføres til den visuelle sekvens af bogstaver og ord, og lineariteten bliver således det organiserende princip. Dette sekventielle udgangspunkt savner imidlertid den operative betydning som er indeholdt $\mathrm{i}$ det skrevne tegns simultanitet. Der hersker ingen tvivl om at skrift og læsning er tidslige processer, mens tekster - som allerede etymologisk antyder en vævet tekstiloverflade - benytter to dimensioner. De udfolder sig ikke kun på lineær vis fra højre mod venstre (og vice versa), men benytter sig også af forskellen mellem foroven eller forneden. Skriftlige spil, såsom krydsord og sudoko, er de mest træffende demonstrationer af dette. Men også den måde hvorpå den videnskabelige tekst er distribueret $i$ brødtekst og fodnoter, måden matematiske beregninger laves på - hvor tal manipuleres under hinanden - og måden hvorpå musikalsk notation angiver samklangen af instrumenter på et nodeblad, viser hvordan den diakrone linearitet brydes op til fordel for en synkron rumlighed.

Hvad der adskiller skrevne tekster fra akustiske lydstrømme er således nøjagtig ophævelsen af linearitetsprincippet (Harris 1990: 39; Groß 1990: 238) - hvilket præcis er hvad som forbinder dem med alle former for billeder. Hvad der adskiller skrevne tekster fra normale billeder og fotografier er deres mellemrumlighed (Zwischenräumlichkeit): de behøver tomme pladser og mellemrum for at være visuelt aflæselige og operativt håndterbare som konfigurationer. En skreven tekst er afhængig af at have elementerne i sit tegnrepertoire til at fremstå organiseret i rumlige planer. Det skrevne er en konfiguration som kan formes og transformeres, en differentialitet som kan struktureres og som omstrukturerer på en semantisk produktiv måde. Elementernes rumlige placering bidrager til betydning og mening. Tænk på fodnoter, indholdsfortegnelser, titler og indekser, noder i musik - eller se på tallene i titallets positionssystem, hvor værdien af et ciffer afgøres af dets position i det numeriske 
udtryk. Hvad der bliver åbenbart er, at den rumlige placering ofte udgør, eller i det mindste fremkalder, betydningen af noget skrevet.

Deres egenskab af disjunktivt 'ordningsmønster' (Anordnung) (Cancik-Kirschbaum/Mahr 2005) adskiller skrevne tekster fra talesprog. Når vi taler, arrangerer vi ikke fonemerne, vi holder ikke pauser mellem vores ord og sætninger. Den teknologiske optagelse af mundtlig tale viser et ophold når taleren skal have vejret, men disse ophold korresponderer ikke med den syntaktiske ordning af det talte. Tale er strøm, et næsten kontinuerligt akustisk flow. At opdele den akustiske strøm i fonemer har intet fysisk fundament (Coulmas 1993: 192, Coulmas 1981). Fonemet som sproglig enhed er en projektion af grafemet (Lüdtke 1969; Klein 1985). Det særskilte tegn isolerer ikke blot grafemerne fra hinanden, det introducerer også grammatisk forskel i form af store og små bogstaver og tegnsætning, hvoraf intet genfindes i det talte sprogs flux. Heri ligger årsagen til at skriftsprog ikke kan være en imitation af det mundtlige. Modsat, det skrevne tegn tilbyder en kartografi over sprog, det gør sprog observerbart og designer sprog som et uafhængigt semiotisk system, løsrevet fra mimik, gestik, prosodi og situeret deiksis.

\section{Et eksempel}

Følgende eksempel demonstrerer hvad det betyder at den rumlige relation fungerer som medium og miljø for skriften, som en form for tænkning (Hayes 2006). Det er en anekdote om matematikeren Carl Friedrich Gauss som barn. En lærer stiller klassen den opgave at beregne summen af de første 100 naturlige tal. Den 9-årige Gauss præsenterer det korrekte svar '5050' efter kun fem minutters arbejde. Det er ikke vanskeligt at forklare hans elementære princip: Løsningen afhænger af en manipulering af den rumlige organisering af de skrevne tal via operationer som grupperer og omgrupperer den sekventielle orden af numre.

Således kan rækkefølgen af de første 100 naturlige tal skrives som følger: 


\section{(1) $1+2+3+4+5+\ldots+97+98+99+100$}

Den kommutative lov om addition siger at den rækkefølge hvori du lægger tallene sammen er vilkårlig, faktorerne kan bytte plads når du lægger dem sammen (commutare, lat. ombytning). Den associative additionslov siger at faktorerne som skal lægges sammen kan blive vilkårligt underordnet inden for parenteser og associeres på en hvilken som helst måde. I stedet for

' $1+2+3+4+5$ ' kunne vi skrive ' $(1+2)+(3+4)$ ' eller ' $1+(2+3)+4$ '

Derfor kan talrækken (1), ved at bytte pladser og grupperinger, også skrives på en anden måde således at, i stedet for den sekventielle orden, det første og det sidste tal, det andet og det næstsidste osv. kan blive sammenstillet og gjort til dele af en gruppe som er holdt sammen af parentesen.

(2) $(1+100)+(2+99)+(3+98)+\ldots+(49+52)+(50+51)$

Det som bliver åbenlyst ved denne operation er, at summen af hver parentes er den samme, nemlig 101.

(3) $(101)+(101)+\ldots+(101)+(101)$

Af dette følger at hvis vi har 50 sådanne parenteser, må regnestykket 101x50 udregnes. Således er 5050 den sum Gauss som en lille dreng beregnede på et par minutter. Og hvis vi skriver dem ned, den ene under den anden:

$$
\begin{aligned}
& \text { (4) } 1+100=101 \\
& 2+99=101 \\
& 3+98=101 \\
& \text {.. } \ldots \text {... } \\
& 49+52=101 \\
& 50+51=101 \\
& 5050
\end{aligned}
$$


Tricket med denne opdagelse af den matematiske formel for addition ligger i opbrydningen af sekventialiteten i den 'naturlige' rækkefølge af talsekvensen: kæden på 100 faktorer forvandles til en kxde med kun 50. Gennem denne omstrukturering af et aritmetisk udtryk genereres en ny konfiguration, som åbner for en kognitiv aha-oplevelse, en pludselig indsigt: at hver af de nyligt skabte grupper har samme værdi: '101'. Bruddet med de skrevne tals strikse sekvens til fordel for en genmodellering hvori 'de sidste skal blive de første' forårsager en andring af aspekter i den form hvormed en numerisk serie optræder. I lighed med Gottlob Freges morgen- og aftenstjerne som modi hvori Venus fremtræder for det menneskelige øje (Frege 1892: 32), er der her forskellige modaliteter hvormed vi kan repræsentere og organisere de første 100 hele tal. For Frege er planeten Venus referencen, mens morgen- og aftenstjernen kaldes meningen ${ }^{7}$ (Frege 1892: 26). I vores aritmetiske operation forbliver referencen af summen den samme, men meningen - forstået som den specifikke udtryksform - har ændret sig. Denne 'opsættelse af mening' via 'lighed i reference,' er muliggjort gennem en ikke-lineær manipulering af et grafisk arrangement.

Siden vi nu har karakteriseret det skrevne tegns implicitte rumlighed, tager vi et nærmere kig på det skrevne ords grafisme.

\section{Grafisme}

Selvom der findes skrevne tekster som ikke primært retter sig mod optisk tilegnelse - tænk på computerens binære alfabet bestående af elektriske impulser, eller på Braille's blindeskrift - så inkarnerer den grafiske inskription hvad enten den er skåret ind i eller påført oven på en materiel overfalde, en paradigmatisk fremtrædelsesform typisk for skrevne tekster. Uden styringen af et skriveredskab og uden støtten fra det tilpassede materiale

\footnotetext{
7 O.A. Gottlob Freges artikel "Über Sinn und Bedeutung" er på dansk oprindeligt oversat som "Om mening og reference". Det bør bemærkes, at eftersom nærværende artikel er oversat fra engelsk og ikke tysk, kan en vis forvirring opstå, idet Krämer benytter den gængse engelske oversættelse af Freges 'Bedeutung', som er 'meaning', mens 'Sinn' oversættes med 'sense.' Således oversætter jeg ikke 'meaning' (Bedeutung) i Krämers engelske originaltekst med det danske 'mening', men derimod med 'reference', hvorimod 'sense'(Sinn) i oversættelsen bliver til 'mening.'
} 
som tillader os at påføre det skrift, kan der ikke eksistere nogen skreven tekst (Greber et al. (eds) 2002; Ehlich 2002).

Fra en palæontologisk synsvinkel var det vores oprejste, tobenede gang som befriede vores hænder og gjorde os i stand til at løfte blikket, og således skabe en ny relation mellem hånd og værktøj, og mellem ansigt og synsaktivitet (Leroi-Gourhan 1980). ${ }^{8}$ Grafisme opstår i kombinationen mellem den tegnende hånd og det læsende øje. Dette leder André Leroi-Gourhan til at antage at billedlige handlinger, såsom at tegne og producere samt at læse grafiske symboler, først opstod med homo sapiens der eksisterede intet sammenligneligt førhen (Leroi-Gourhan 1980: 238). Grundlaget for grafisme udgøres af stregen eller linjen, som, sammen med punktummet, udgør notationers elementære repertoire. Fænomenet krusedulleskrift er også oplysende, idet det demonstrerer den allestedsnærværende magt der ligger i at udføre grafiske operationer, selv hinsides konventionerne (Driesen 2012). At trække en streg er, på samme tid sporet af en kropslig bevægelse og en løsrevet, fri skitse. Vi designer en verden i skriften og i det vi gør det, bruger vi tegn som er strengt konventionelle; men denne nedskrevne verden er, nolens volens - som et spor af en bevægelse, eller en persons udtryk bærer af den personlige håndskrift og af sin forfatters unikke signatur (Böhm/Gätje 2014; Krämer 2014).

Vigtigheden af grafisme for vores kunstneriske og intellektuelle udvikling kan ikke undervurderes. At være i stand til at tale et sprog betragtes generelt som altafgørende for kulturen. Men evnen til grafisk og billedligt udtryk er lige så vigtigt som vores mundtlige evne. Og dette gælder a fortiori for vores kognitive præstationer og for de medier vi gør brug af i vores kognition. Allerede Leibniz understregede at 'tegnede og skrevne tegn' er uerstattelige når det kommer til tænkning og forståelse (Leibniz 1705). Et kort blik på videnskabelige publiceringsstrategier gør det tydeligt at disse ikke alene er afhængige af skrevne tekster, men også af tabeller, grafer, diagrammer og kort. Der ville ikke være nogen videnskab uden visualisering i skrift, billeder, grafer og diagrammer. Og dette gælder ikke alene for den generelle

8 Om forholdet mellem sprog og gestik, se Armstrong/Stokoe/ Wilcox 1995. 
præsentation og cirkulation af information, men også for den originale videnskabelige argumentations- og forskningsproces (Hoffmann 2008; Latour 1990).

Det er derfor begrebet 'grafisme' er et begreb som, på den ene side, understreger ligheden mellem skrevne tekster og andre former for grafisk repræsentation som udtrykkes prototypisk af kort, grafer og diagrammer; og på den anden side understreger den udforskende og kreative rolle, som skriften spiller - udover den blot repræsenterende rolle. Af de mange muligheder for kognitiv og æstetisk erfaring inden for grafisme, synes relationen mellem rum og tid at være en af de mest relevante. Det grafiske mærke er altid også en teknik til at rumliggøre temporale processer: lineære forløb krystalliseres til simultanitet. Og modsat, stabile skrevne strukturer kan gøres til flydende temporale processer. Dette sker når en tekst læses højt som en tale, når et partitur transformeres til opført musik, eller når et computerprogram bliver brugt. Grafisme oversætter tid til rum og rum til tid. Dette kan sagtens vise sig at være kernen til den effektivitet, som denne kulturtekniske praksis har vist sig at have.

\section{Fortolkelighed}

Det skrevne tegn lever i to verdner: det fremtræder empirisksensorisk som et 'mærke' der er situeret i tid og sted. Men under læsning forvandler det sig også til identifikationen af en type, et skematiseret mærke som ikke signalerer noget bestemt, men snarere noget generelt. Selv om den visuelle overflade fremstår afgørende, kan et grafisk mærke kun tælle som en form for skrift når det referer til noget uden for og ud over sig selv. I kontrast til almindelige poststrukturalistiske positioner, så eksisterer der et 'uden for teksten.' Denne ydre dimension kan referere til andre tekster, til talt sprog, men også til musikalske lyde, dansetrin, koncepter, tal, computerkommandoer, logiske operationer osv. Uden ekstern referent, uden semantik, er der ikke skrift, kun ornament. Og dog kræver læsning, afkodning og tolkning også altid at vi ignorerer det skrevnes empiriske sensualitet og konkrete æstetiske overskud. Både kalligrafi og andre stædige former for håndskrift undergraver denne skematiske maksime og 
fremmedgør den. Et skriftlignende fænomen uden en semantik kan være kunst men det er hverken et eksempel på skriften som medium eller som redskab.

Ikke desto mindre - og dette er min pointe - så afhænger de operationer vi udfører med skrevne tekster ofte af udsattelsen af deres tolkning. Materialiteten, synligheden og operativiteten af det skrevne tegn er i stand til at sikre den grafiske overflades relative autonomi i forhold til dets tolkelige indhold. Skriftens epistemiske potentiale drejer omkring den præmis at konstruktion og tolkning kan tage adskilte veje. Bare tænk på eksemplet med cifferet nul: ' 0 '. Længe før nogen havde opstillet en matematisk tolkning sådan som George Booles' 'tomme mængde' for tallet nul, blev det skrevne tegn ' 0 ' brugt i vellykkede udregninger (Kaplan 2001; Rotman 1987; Krämer 1988: 54-59). Vi behøver ikke vide hvad ' $O$ ' betyder, eller om det overhovedet er et tal, for at være i stand til at regne med det. Konstruktionen og brugen af skrevne tal foregår deres matematiske fortolkning. Det var først efter århundreder hvor titalssystemet havde været i brug og fungeret effektivt at en helt ny forståelse af tal opstod: Et talbegreb blev skabt, som adskiller tal fra deres tælbarhed, fra forståelsen af dem som entiteter, der kan tælles.

Den kreative dimension $i$ at bortse fra mening findes ikke kun inden for matematikken. Også poesi lever af muligheden for opsættelse og udsættelse af mening. Kun fordi de skrevne ord $i$ et digt er sat sammen i usædvanlige og innovative konstellationer, er poesi i stand til at 'befri' sproget, så det får et eget liv, som ofte aldrig er hørt før. De formelle og poetiske udnyttelser af det skrevne ord trækker således begge på formens suverænitet over indholdet i skriften.

\section{Mekaniserbarhed}

Denne formens suverænitet over for indholdet indikerer en mekanisk kerne i skriftens brug. Det er ikke noget tilfælde at introduktionen af det indisk-arabiske talsystem med skrevne tegn producerede den første mekaniske regnemaskine, idet konfigurationer af ciffertegnene kunne inkarneres gennem mekaniske 
positioner (Krämer 1988; Künzel/Bexte 1993, 1996). Computeren - som i dag især bruges som netværk til kommunikation samt til visualisering og simulation - er og vedbliver at være en tekstbaseret maskine (Bolter 1991, 1997; Hayles 2000). Ordet 'gramma' græsk for 'bogstav,' minder os om programmeringens skriftlige natur. Ikke alene at skrive, læse og regne, men også programmering repræsenterer brugen af manuskript som en kulturteknik (Bolter 2005). Kun det binære alfabet som blev opfundet af Leibniz (Leibniz: 1705), og som for mennesker er både forvirrende og uudsigeligt at benytte som beregningsværktøj, muliggør digitaliseringen af vores kultur i betydningen af at forberede maskiner på at lave et medium om til et andet. Computeres aktiviteter er baserede på en overførsel af skrevne strukturer til operationer udført af elektriske impulser, som er usynlige for det menneskelige øje. Uden den synoptiske præsentation af digitaliserede dataproduktioner på computerskærmens flade samtidighed ville denne teknik imidlertid køre til ingen nytte.

Skriften får et nyt karaktertræk i vores digitale kultur. Det begynder med stregkoden, som identificerer ting med henblik på at introducere dem og implementere dem i en virtuel verden. Det er den særlige kvalitet ved digitaliseret brug af skrift at tidslighed kan overføres til skrevne teksters rumlige konfigurationer. Når vi skriver og læser gør vi normalt noget med de skrevne tegn og derfor har vi brug for at de er stabile. Men computerens 'auto-operative' skrift ${ }^{9}$ handler autonomt, dog naturligvis inden for en given programmeret ramme for aktion og reaktion. Som konsekvens af dette indtager de symbolske strukturer en mere dynamisk form, som er prototypisk realiseret i computersimuleringer (Gramelsberger 2010: 255-275). Desuden møder vi den digitale skrifts selv-operative kvalitet i 'linket', som er et fænomen, der giver os adgang til internettets bredt forbundne dataunivers. Kort sagt: indtil computerens tidsalder repræsenterede skrevne tekster en kulturteknik til rumlig strukturering af information; hvad der bliver mere og mere klart nu er imidlertid at skriften i den digitale sfære er avanceret til en kulturteknik,

9 Dette begreb diskuteres af Grube 2005. 
der strukturerer information temporalt. Forbindelsen mellem rum og tid i den digitale skrift er meget mere kompliceret. Men implementeringen af den tidslige operativitet i det der nedfældes på skrift er et bemærkelsesværdigt nyt stadie i skriftens udviklingshistorie.

\section{Konklusion}

'Notationel ikonicitet' er et strategisk begreb. Det tjener til at suspendere den reduktionisme som er implicit i den skrevne tekst forstået som nedskrevet sprog, til fordel for et skriftbegreb som er uafhængigt af det talte sprog. Det har til formål at vende sig bort fra en udbredt holdning inden for humaniora: Tendensen til at opdele vores symbolske færdigheder i to adskilte sfærer, en sproglig og en billedlig. Alligevel er det at erkende inskriptioners aflæselighed og operativitet ikke det samme som at befri skriften fra den sproglige diskurs og allokere den til billedernes diskurs. At inskription er visuel betyder således ikke at skrift er et billede. Vi ønsker ikke at introducere en 'ikonisk vending' i debatten om skrift. Dette af den grund, at der kan sås megen tvivl omkring hvorvidt der overhovedet eksisterer sådan noget som et "rent sprog" eller et "rent billede".

Hvad som giver mening metodisk er at lade begreberne "sprog" og "billede" markere de to yderpunkter i en skala, mellem hvilke næsten alle vores symbolske bedrifter kan lokaliseres som blandingsfenomener i forskellige grader af diskursivitet og ikonicitet. Afgørende for det diskursive perspektiv, er skriftens distinkthed og dens syntaktiske beskaffenhed, såvel som dens evne til at repræsentere noget. Dog behøver denne repræsenterende evne ikke at være noget sprogligt: det kunne også være tal, musikalske lyde, maskinkommandoer, logiske enheder, kemiske grundstoffer og dansetrin. For det ikoniske perspektiv gælder synligheden og det todimensionelle samtidighedsprincip. I inskriptioner er udsigelsens og visningens modi forbundne; men den specifikke blanding af det sproglige og det ikoniske adskiller sig for hver type af skrift og må udfoldes hver for sig. Skrevne tekster følger ikke tvedelingen mellem at være enten sprog eller billede; som hybrider udtrykker de begge dele: noget som 
er både sprogligt og ikonisk. Begrebet 'notationel ikonicitet' orienterer sig efter den præmis at skriftens laboratorium kan frigøre kognitive og æstetiske processer og erfaringer, for hvilke der ikke eksisterer nogen modeller eller prototyper i hverken det rene sprogs eller den rene ikonicitets sfærer. 


\section{Referencer}

Assmann, Jan. 1992. Das kulturelle Gedächtnis: Schrift, Erinnerung und politische Identität in frühen Hochkulturen. München: Beck.

Böhm, Manuela og Olaf Gätje. 2014. "Handschreiben - Handschriften Handschriftlichkeit: Zu Praktiken, Materialität und Theorie des Schreibens mit der Hand". Osnabrücker Beiträge zur Sprachtheorie (OBST) 85.7-22.

Bolter, Jay D. 1991. The computer, hypertext and the history of writing. Hillsdale, NJ: Erlbaum Association.

Bolter, David J. 1997. "Das Internet in der Geschichte der Technologien des Schreibens". Mythos Internet. Stefan Münker og Alexander Roesler (red.), 37-55. Frankfurt am Main: Suhrkamp.

Bolter, David J. 2005. "Digitale Schrift". I: Schrift: Kulturtechnik zwischen Auge, Hand und Maschine. Gernot Grube, Werner Kogge og Sybille Krämer (red.), 453-468. Paderborn, München: Fink.

Brandstetter, Gabriele, Franck Hofmann og Kirsten Maar. 2010. Notationen und choreographisches Denken. Freiburg i. Br., Berlin, Wien: Rombach.

Campe, Rüdiger. 1991. "Die Schreibszene. Schreiben”. I: Paradoxien, Dissonanzen, Zusammenbrüche: Situationen offener Epistemologie. Hans U. Gumbrecht og Karl L. Pfeiffer (red.), 759-772. Frankfurt am Main: Suhrkamp.

Cancik-Kirschbaum, Eva. 2005. "Beschreiben, Erklären, Deuten: Ein Beispiel für die Operationalisierung von Schrift im alten Zweistromland". I: Schrift: Kulturtechnik zwischen Auge, Hand und Maschine. Gernot Grube, Werner Kogge og Sybille Krämer (red.), 399-411. Paderborn, München: Fink.

Cancik-Kirschbaum, Eva og Bernd Mahr. 2005. "Anordnung und ästhetisches Profil". I: Bildwelten des Wissens: Kunsthistorisches Jahrbuch für Bildkritik, Diagramme und bildtextile Ordnungen, Horst Bredekamp og Gabriele Werner (red.), 96-114. Berlin: Akademie Verlag.

Coulmas, Florian. 1981. Über Schrift. Frankfurt am Main: Suhrkamp. Coulmas, Florian. 1993. "Das ABC der Wissenschaft". Merkur 3: 390398.

Damerow, Peter. 1993. "Buchhalter erfanden die Schrift". Rechtshistorisches Journal 12: 9-35.

Driesen, Christian, red. 2012. Über Kritzeln: Graphismen zwischen 
Schrift, Bild, Text und Zeichen. Zürich: Diaphanes.

Ehlich, Konrad. 1994. "Funktion und Struktur schriftlicher Kommunikation". I: Schrift und Schriftlichkeit. Ein interdisziplinäres Handbuch internationaler Forschung, Hartmut Günther og Otto Ludwig (red.), 18-41. Berlin: de Gruyter.

Ehlich, Konrad. 2002. "Schrift, Schriftträger, Schriftform: Materialität und semiotische Struktur". I: Materialität und Medialität von Schrift. Erika Greber, Konrad Ehlich og Jan-Dirk Müller (red.), 91-112. Bielefeld: Aisthesis.

Ernst, Wolfgang og Friedrich A. Kittler (red.). 2006. Die Geburt des Vokalalphabets aus dem Geist der Poesie: Schrift, Zahl und Ton im Medienverbund. München: Fink.

Falk, Harry. 1990. "Goodies for India. Literacy versus Non-Literacy. The Great Divide". I: Modes of thought: Essays on Thinking in Western and Non-Western Societies red. af Ruth Finnegan og Robin Horton, 103-120.

Finnegan, Ruth. 1973. "Literacy and Non-Literacy: The Great Divide? Some Comments on the Significance of 'Literature' in Non-Literate Cultures". I: Modes of thought: Essays on thinking in Western and non-Western societies, Robin Horton og Ruth H. Finnegan (red.), 112-144. London: Faber.

Frege, Gottlob. 1962. "Über Sinn und Bedeutung”. I: Funktion, Begriff, Bedeutung: Fünf logische Studien, Günther Patzig (red.), 38-63. Göttingen: Vandenhoeck og Ruprecht.

Giuriato, Davide og Stephan Kammer. 2006. "Die graphische Dimension der Literatur? Zur Einleitung". I: Bilder der Handschrift: Die graphische Dimension der Literatur. Davide Giuriato og Stephan Kammer (red.), 7-24. Frankfurt am Main: Stroemfeld.

Giuriato, Davide, Martin Stingelin og Sandro Zanetti. 2008. Schreiben heisst: sich selber lesen: Schreibszenen als Selbstlektüren. München: Fink.

Gong, Yushu. 2009. "The Accounts of the Origin of Writing from Sumer, Egypt and China - A Comparative Perspective". Wiener Zeitschrift zur Kunde des Morgenlandes 99: 137-158.

Goody, Jack. 1968. Literacy in traditional societies. Cambridge: Cambridge U.P.

Goody, Jack. 1986. The logic of writing and the organization of society. 
Cambridge [Cambridgeshire], New York: Cambridge University Press. Gramelsberger, Gabriele. 2010. Computerexperimente: Zum Wandel der Wissenschaft im Zeitalter des Computers. Bielefeld: transkription. Greber, Erika. 2002. Textile Texte: Poetologische Metaphorik und Literaturtheorie: Studien zur Tradition des Wortflechtens und der Kombinatorik. Bd. 9. Köln: Böhlau.

Greber, Erika, Konrad Ehlich og Jan-Dirk Müller, red. 2002. Materialität und Medialität von Schrift. Bielefeld: Aisthesis.

Groß, Sabine. 1990. "Schrift-Bild: Die Zeit des Augenblicks". I: Zeit-

Zeichen: Aufschübe und Interferenzen zwischen Endzeit und Echtzeit, Georg C. Tholen og Michael O. Scholl. Weinheim (red.), Bundesrepublik Deutschland: VCH, Acta Humaniora.

Groß, Sabine. 1994. Lese-Zeichen: Kognition, Medium und Materialität im Leseprozess. Darmstadt: Wissenschaftliche Buchgesellschaft.

Grube, Gernot. 2005. "Autooperative Schrift - und eine Kritik der Hypertexttheorie". Schrift: Kulturtechnik zwischen Auge, Hand und Maschine, Gernot Grube, Werner Kogge og Sybille Krämer (red.), 81-114. Paderborn, München: Fink.

Grube, Gernot, Werner Kogge og Sybille Krämer, red. 2005. Schrift: Kulturtechnik zwischen Auge, Hand und Maschine. Paderborn, München: Fink.

Günther, Hartmut. 1995. "Die Schrift als Modell der Lautsprache”. Osnabrücker Beiträge zur Sprachtheorie (OBST) 51.15-32.

Günther, Hartmut og Otto Ludwig, red. 1994-1996. Schrift und Schriftlichkeit. Writing and its Use. Ein interdisziplinäres Handbuch internationaler Forschung. Berlin: de Gruyter.

Havelock, Eric A. 1976. Origins of western literacy: Four lectures delivered at the Ontario Institute for Studies in Education, Toronto, 25. marts, 26,27, 28, 1974. Toronto: Ontario Institute for Studies in Education.

Havelock, Eric A. 1986. The muse learns to write: Reflections on orality and literacy from antiquity to the present. New Haven: Yale University Press.

Hayes, Brian. "Gauss's Day of Reckoning”. American Scientist 2006:94, 137-158.

Hayles, Katherine. 2002. Writing machines. (= Mediawork pamphlet.) Cambridge, Mass. MIT Press. 
Hoffmann, Christoph. 2008. Daten sichern: Schreiben und Zeichnen als Verfahren der Aufzeichnung. Berlin: Diaphanes Verlag.

Hoffmann, Christoph. 2010. "Schreiben als Verfahren der Forschung". I: Experiment und Literatur: Themen, Methoden, Theorien, Michael Gamper (red.), 181-207. Göttingen: Wallstein-Verl.

Kaplan, Robert. 2000. The nothing that is: A natural history of zero. Oxford, New York: Oxford University Press.

Kittler, Friedrich. 2003. "Zahl und Ziffer". I: Bild, Schrift, Zahl, Sybille Krämer og Horst Bredekamp (red.), 193-204. München: Fink.

Klein, Wolfgang. 1985. "Gesprochene Sprache - Geschriebene Sprache". Zeitschrift für Literaturwissenschaft und Linguistik 59, 9-35. Klein, Ursula, Timothy Lenoir og Hans U. Gumbrecht. 2003. Experiments, models, paper tools: Cultures of organic chemistry in the nineteenth century, Stanford, Calif. Stanford University Press.

Koch, Peter. 2009. "Graphé: Ihre Entwicklung zur Schrift, zum Kalkül und zur Liste". I: Schrift, Medien, Kognition: Über die Exteriorität des Geistes, Peter Koch og Sybille Krämer (red.), 43-82. Tübingen: Stauffenburg.

Koch, Peter og Sybille Krämer, red. 2009. I: Schrift, Medien, Kognition: Über die Exteriorität des Geistes. Tübingen: Stauffenburg.

Koch, Peter og Wulf Oesterreicher. 1985. Sprache der Nähe - Sprache der Distanz: Mündlichkeit und Schriftlichkeit im Spannungsfeld von Sprachtheorie und Sprachgeschichte. (= Romanisches Jahrbuch 36, s. 15-43.)

Krämer, Sybille. 2014. "Trace, Writing, Diagram: Reflections on Spatiality, Intuition, Graphical Practices and Thinking”. I: The power of the image: Emotion, expression, explanation. András Benedek, Kristóf Nyiri (red.), Peter Lang GmbH, Frankfurt am Main 2014, 3-22.

Krämer, Sybille, red. 2004. Performativität und Medialität. München: Fink.

Krämer, Sybille. 1988. Symbolische Maschinen: Die Idee der Formalisierung in geschichtlichem Abriss. Darmstadt: Wissenschaftliche Buchgesellschaft.

Krämer, Sybille. 1996. "Sprache und Schrift oder: Ist Schrift verschriftete Sprache”. Zeitschrift für Sprachwissenschaft 15, 1.92-112.

Krämer, Sybille. 2003a. "Kultur, Technik, Kulturtechnik". I: Bild, Schrift, 
Zahl, Sybille Krämer og Horst Bredekamp (red.), 11-22. München: Fink.

Krämer, Sybille. 2003b. "Writing, Notational Iconicity, Calculus: On writing as a Cultural Technique". I: Modern Languages Notes - German Issues, vol 118, No 3, 518-537 (tysk: ",Schriftbildlichkeit" oder: Über eine (fast) vergessene Dimension der Schrift”. Bild, Schrift, Zahl, Sybille Krämer og Horst Bredekamp (red.), 157-176. München: Fink).

Krämer, Sybille. 2004. "Friedrich Kittler - Kulturtechniken der Zeitachsenmanipulation". I: Medientheorien: Eine philosophische Einführung, Alice Lagaay og David Lauer (red.), 201-224. Frankfurt, New York: Campus.

Krämer, Sybille. 2005. "'Operationsraum Schrift': Über einen Perspektivenwechsel in der Betrachtung der Schrift". I: Schrift: Kulturtechnik zwischen Auge, Hand und Maschine, Gernot Grube, Werner Kogge og Sybille Krämer (red.), 23-60. Paderborn, München: Fink.

Krämer, Sybille. 2005. "Mündlichkeit/Schriftlichkeit”. I: Grundbegriffe der Medientheorie, Alexander Roesler og Bernd Stiegler (red.). Paderborn: Fink.

Krämer, Sybille. 2006. "Leerstellen-Produktivität". I: Instrumente in Kunst und Wissenschaft: Zur Architektonik kultureller Grenzen im 17. Jahrhundert, Helmar Schramm, Ludger Schwarte og Jan Lazardzig (red.), 502-526. Berlin, New York: Walter de Gruyter.

Krämer, Sybille. 2010. "Notationen, Schemata und Diagramme: Über ,Räumlichkeit' als Darstellungsprinzip. Sechs kommentierende Thesen". I: Notationen und choreographisches Denken, Gabriele Brandstetter, Franck Hofmann og Kirsten Maar (red.), 29-46. Freiburg i. Br., Berlin, Wien: Rombach.

Krämer, Sybille. 2012. "Punkt, Strich, Fläche: Von der Schriftbildlichkeit zur Diagrammatik”. I: Schriftbildlichkeit: Wahrnehmbarkeit, Materialität und Operativität von Notationen. Sybille Krämer, Eva Cancik-Kirschbaum og Rainer Totzke (red.), 79-100. Berlin: Oldenbourg Wissenschaftsverlag $\mathrm{GmbH}$.

Krämer, Sybille. 2014. “Über die Handschrift: Gedankenfacetten”. Osnabrücker Beiträge zur Sprachtheorie (OBST) 85.23-34.

Krämer, Sybille og Horst Bredekamp, red. 2003. Bild, Schrift, Zahl. München: Fink.

Krämer, Sybille, Eva Cancik-Kirschbaum og Rainer Totzke, red. 2012. 
Schriftbildlichkeit: Wahrnehmbarkeit, Materialität und Operativität von Notationen. (= Schriftbildlichkeit, 1.) Berlin: Oldenbourg Wissenschaftsverlag $\mathrm{GmbH}$.

Krämer, Sybille og Mareike Giertler, red. 2011. Schriftbildlichkeit. München.

Krämer, Sybille og Mareike Giertler. 2011. "Schwerpunkt ,Schriftbildlichkeit". Sprache und Literatur 42, 1. Halbjahr: 107.

Künzel, Werner og Peter Bexte. 1993. Allwissen und Absturz: Der Ursprung des Computers. Frankfurt am Main: Jüdischer Verl.

Künzel, Werner og Peter Bexte. 1996. Maschinendenken, Denkmaschinen: An den Schaltstellen zweier Kulturen. Frankfurt am Main: Insel.

Latour, Bruno. 1990. "Drawing Things Together". Representation in scientific practice, Michael Lynch og Steve Woolgar (red.), 19-68. Cambridge, Mass. MIT Press.

Leibniz, Gottfried Wilhelm. 1705., Explication de l'Arithmetique Binaire". I: Histoire de l'academie Royale des Sciences Paris 1705 (genoptrykt: Herrn von Leibniz Rechnung mit Null und Eins, udgivet af Siemens Aktiengesellschaft Berlin München 1979, 3. oplag.).

Leroi-Gourhan, André. 1980. Hand und Wort: Die Evolution von Technik, Sprache und Kunst. Frankfurt am Main: Suhrkamp.

Lüdeking, Karlheinz. 2006. "Bildlinie/Schriftlinie". Grenzen des Sichtbaren, Karlheinz Lüdeking (red.), 144-158. München: Wilhelm Fink.

Lüdtke, Helmuth. 1969. "Die Alphabetschrift und das Problem der Lautsegmentierung". Phonetik 20, 147-176.

Magnus, David. 2011. "Transkription und Faktur musikalischer Zeichen bei Anestis Logothetis". Schriftbildlichkeit, Sybille Krämer og Mareike Giertler (red.), 81-92. München.

Mersch, Dieter. 2005. "Die Geburt der Mathematik aus der Struktur der Schrift". Schrift: Kulturtechnik zwischen Auge, Hand und Maschine. Gernot Grube, Werner Kogge og Sybille Krämer (red.), 211-236. Paderborn, München: Fink.

Mersch, Dieter. 2012. "Schrift/Bild - Zeichnung/Graph - Linie/Markierung. Bildepisteme und Strukturen des ikonischen ,Als". Schriftbildlichkeit: Wahrnehmbarkeit, Materialität und Operativität von Notationen, Sybille Krämer, Eva Cancik-Kirschbaum og Rainer Totzke (red.), 305-328. Berlin: Oldenbourg Wissenschaftsverlag GmbH.

Olson, David R. 1991. "Literacy as Metalinguistic Activity". Literacy and 
orality, David R. Olson og Nancy Torrance (red.), 251-270. Cambridge, New York: Cambridge University Press.

Ong, W. J. 1982. Orality and Literarcy: The Technologizing of the Word. London/New York.

Parry, Milman. 1971. The making of Homeric Verse, I: The collected papers of Milman Parry, Oxford: Clarendon Pr.

Raible, Wolfgang. 1991. Die Semiotik der Textgestalt: Erscheinungsformen und Folgen eines kulturellen Evolutionsprozesses. Heidelberg: C. Winter.

Raible, Wolfgang. 1993. "Die Entwicklung ideographischer Elemente bei der Verschriftlichung von Wissen". I: Vermittlung und Tradierung von Wissen in der griechischen Kultur, Wolfgang Kullmann og Jochen Althoff (red), 15-37. Tübingen: G. Narr.

Raible, Wolfgang. 2004. "Über das Entstehen der Gedanken beim Schreiben". Performativität und Medialität, Sybille Krämer (red.), 191-214. München: Fink.

Raible, Wolfgang. 2009. "Von der Textgestalt zur Texttheorie. Beobachtungen zur Entwicklung des Text-Layouts". Schrift, Medien, Kognition: Über die Exteriorität des Geistes. Peter Koch og Sybille Krämer (red.), 29-42. Tübingen: Stauffenburg.

Rheinberger, Hans J. 1999. "Alles, was überhaupt zu einer Inskription führen kann”. Wissensbilder: Strategien der Überlieferung, Ulrich Raulff og Gary Smith (red.), 265-277. Berlin: Akademie Verlag. Roy, Harris. 1990. "On Redefining Linguistics". I: Redefining linguistics red. af Hayley G. Davis og Talbot J. Taylor, 18-52. London, New York: Routledge.

Schmandt-Besserat, Denise. 1992. Before writing. Austin: Univ. of Texas Pr.

Schröter, Jens. 2004. "Intermedialität, Medienspezifik und die universelle Maschine". I: Performativität und Medialität, Sybille Krämer (red.). München: Fink.

Stingelin, Martin. 1999., Unser Schreibzeug arbeitet mit an unseren Gedanken: Die poetologische Reflexion der Schreibwerkzeuge bei Georg Christoph Lichtenberg und Friedrich Nietzsche, I LichtenbergJahrbuch 1999 [2000], 81-98.

Summers, David. 2003. Real spaces: World art history and the rise of Western modernism. London, New York, NY: Phaidon Press. 
Wilcke, Claus. 2000. Wer las und schrieb in Babylonien und Assyrien: Überlegungen zur Literalität im Alten Zweistromland. München: Verlag der Bayerischen Akademie der Wissensschaften.

Zanetti, Sandro, red. 2012. Schreiben als Kulturtechnik: Grundlagentexte. Berlin: Suhrkamp.

Zumthor, Paul. 1984. La poésie et la voix dans la civilisation médiévale. (= Essais et conférences / Collège de France.) Paris: Presses universitaires de France. 



\title{
Om Flatland (1884) och Flatland (2007)
}

\author{
Jakob Lien
}

År 1884 kunde man i de engelska bokhandlarna finna en tunn liten bok med titeln Flatland: A Romance of Many Dimensions publicerad under pseudonymen "A. Square". Boken som till en början inte rönte ett särskilt stort intresse visade sig snart vara skriven av den vid tiden välkände brittiske humanisten, samhällsdebattören och teologen Edwin A. Abbott och när upplagan sköt i höjden började snart författarens verkliga namn att dyka upp inom parentes på omslaget.

Denna mycket märkliga roman utspelar sig i en fullständigt platt värld bestående av endast två dimensioner, befolkad av geometriska figurer - streck, trianglar och kvadrater o.s.v. Männen i boken är porträtterade som flerhörningar, där trianglarna utgör arbetarklassen och invånare med fyra hörn eller fler tillhör någon av de högre samhällsklasserna. Desto fler hörn desto högre samhällsklass, där cirkeln anses utgöra den "fulländade formen". Det visar sig dock snart att det vardagliga livet i denna tvådimensionella värld medför en hel del praktiskt bekymmer, för invånarna i Flatland ter sig nämligen alla individer som plat- 
ta streck, som en liten förtjockning i en annars konstant horisontell linje utan något upp och ned. Utan tillträde till en tredje dimension framstår även trianglar och kvadrater som streck, vilket medför att det är först när man är helt nära en annan invånare och med känseln kan avgöra den andres former som man kan avgöra vem det är man har framför sig och till vilken samhällsklass denne tillhör. Kvinnorna i boken utgörs av raka linjer och tvingas utstöta ett speciellt ljud när de rör sig eftersom det förkommit incidenter, medvetna eller olyckshändelser, när manliga invånare stuckits ihjäl då de utifrån sin horisontala synvinkel misstagit kvinnan för att utgöra en punkt och gått rakt in i henne och fått ett dödligt sticksår.

Efterhand förstår man att handlingen återges av ett berättarjag, en kvadrat (A Square) ur "lågadeln" som besökt den tredje dimensionen, Rumsland (Spaceland). Berättaren har sett Flatland från den tredje dimensionen och blandat annat upptäckt att världens alla låsta och igenbommade utrymmen därmed kan stjälas uppifrån (eftersom man utgår från två dimensioner i Flatland har man inga tak på husen). Men kungen i Flatland vägrar att ta till sig av den nya kunskapen. Att något skulle kunna existera utanför två dimensioner är såväl teoretiskt som praktiskt omöjligt, resonerar han. När kvadraten sedan predikar sina nyvunna insikter för invånarna leder det till att många av dem som anammar de nya idéerna fängslas eller avrättas för heresi mot den härskande sanningen.

Efter det kommer kvadraten i en dröm att upptäcka två andra världar: Linjeland (Lineland), en värld bestående av en dimension där invånarna lever på en linje och därmed är låsta till en fast position utan möjlighet att röra sig förbi varandra. Det enda sättet att kommunicera är genom rop. Slutligen kommer han till Punktland (Pointland) som endast består av en punkt bebodd av en kung som inte kan röra sig i någon riktning. När Punktlands enda invånare hör berättarrösten ropa till honom tror han att det är sin egen röst han hör, eftersom han enligt ett slags solipsistisk tradition inte kan föreställa sig att det existera någon annan än han själv.

Idag betraktas Flataland som en kultklassiker och har beskri- 
vits både som matematisk science fiction, samhällssatir och idéroman med ett ben i naturvetenskap och ett ben i filosofi och humaniora. Den har lästs som en skarp satir av det viktorianska samhällets hierarkiska samhällsstruktur och som ett viktigt inlägg i kvinnokampen i förra sekelskiftets England (Abbott var även rektor på en skola i Marylebone och argumenterade för flickors stärkta rätt till utbildning).

Numera är det nog inte i första hand de viktorianska referenserna som lockar nya läsare av boken, utan det nästintill banala tankeexperimentet med dimensioner. Mot slutet av Flatland, när berättarens sinnen väl öppnats upp mot andra dimensioner, väcks tanken på en fjärde dimension, även om det aldrig blir riktigt klart vad denna fjärde dimension är för något. Något som skulle komma att återaktualiseras bara tjugo år senare när Albert Einsteins speciella relativitetsteori lanserades och tanken på en "rumtid", där rummets tre dimensioner + tid kombineras i ett kontinuum, på allvar introducerades.

Men bokens experiment med dimensioner pekar även i en annan riktning, mot den materiella situationen som utgörs av själva boken och det faktum att skriften alltid framträder i ett tvådimensionellt rum som inte har någon motsvarighet i talet helt enkelt vad den vad den tyske mediefilosofen Sybille Krämer omnämner som notationel ikonicitet i den essä som översatts till danska i det här numret av Sensorium Journal.

Just denna skriftens visuella aspekter har den kanadensiska poeten och författaren Derek Beaulieu tagit fasta på i sin kongeniala transponering av Edwin A. Abbotts Flatland från 2007, där han genom en konceptuell operation reducerar textsidans handling till ett tvådimensionellt plan. Med inspiration i såväl den konkreta poesin som modern litteraturteori om en icke-signifierande poesi har Beaulieu arbetat fram en översättningsprincip där textens bokstäver successivt ersatts med linjer. Genom att identifiera den första förekomsten av en unik bokstav på den första raden på varje boksida och sedan radera de övriga skapas en utgångspunkt för det vidare arbetet. Från varje identifierad unik bokstav dras sedan en linje från dess förekomst på första 
raden till dess första förekomst på efterföljande rad, o.s.v., tills ett textblock tar slut. Sedan börjar processen om igen med nästa identifierat unika bokstav.

"The result is a new kind of flatness", skriver Kenneth Goldsmith i en essä om Flatland, "[...] a depthless fiction, one where image and narrative is reduced to line and shadow." Läsningen av Beaulieus Flatland förvandlas till ett slags ett deltagande helt på skriftens eller inskriptionens egna villkor. Läsupplevelsen blir efterhand allt mer ansträngande och sensorisk på samma gång, linjerna börjar flimra framför ögonen och plötsligt märker man hur man sträcker fram handen för att följa linjernas rörelse över boksidan i ett tafatt försök att återskapa den mening som den tvådimensionella ytan framför oss inte längre bär på. Det är ovant, frustrerande och lockande på samma gång. Sybille Krämer skriver att: "[...] skriftens laboratorium kan frigøre kognitive og æstetiske processer og erfaringer, for hvilke der ikke eksisterer nogen modeller eller prototyper i hverken det rene sprogs eller den rene ikonicitets sfærer." Beaulieus Flataland, som löper likt ett seismografiskt EKG över boksidan, är ett perfekt exempel på Krämers skriftlaboratorium. 


\title{
Excerpt from Flatland
}

\author{
Edwin A. Abbott
}

\section{Part I: This World}

"Be patient, for the world is broad and wide."

\section{Of the Nature of Flatland}

I CALL our world Flatland, not because we call it so, but to make its nature clearer to you, my happy readers, who are privileged to live in Space. Imagine a vast sheet of paper on which straight Lines, Triangles, Squares, Pentagons, Hexagons, and other figures, instead of remaining fixed in their places, move freely about, on or in the surface, but without the power of rising above or sinking below it, very much like shadows - only hard and with luminous edges - and you will then have a pretty correct notion of my country and countrymen. Alas, a few years ago, I should have said "my universe": but now my mind has been opened to higher views of things.

In such a country, you will perceive at once that it is impossible that there should be anything of what you call a "solid" kind; but I dare say you will suppose that we could at least dis- 
tinguish by sight the Triangles, Squares, and other figures, moving about as I have described them. On the contrary, we could see nothing of the kind, not at least so as to distinguish one figure from another. Nothing was visible, nor could be visible, to us, except Straight Lines; and the necessity of this I will speedily demonstrate.

Place a penny on the middle of one of your tables in Space; and leaning over it, look down upon it. It will appear a circle.

But now, drawing back to the edge of the table, gradually lower your eye (thus bringing yourself more and more into the condition of the inhabitants of Flatland), and you will find the penny becoming more and more oval to your view; and at last when you have placed your eye exactly on the edge of the table (so that you are, as it were, actually a Flatlander) the penny will then have ceased to appear oval at all, and will have become, so far as you can see, a straight line.

The same thing would happen if you were to treat in the same way a Triangle, or Square, or any other figure cut out of pasteboard. As soon as you look at it with your eye on the edge on the table, you will find that it ceases to appear to you a figure, and that it becomes in appearance a straight line. Take for example an equilateral Triangle - who represents with us a Tradesman of the respectable class. Fig. 1 represents the Tradesman as you would see him while you were bending over him from above; figs. 2 and 3 represent the Tradesman, as you would see him if your eye were close to the level, or all but on the level of the table; and if your eye were quite on the level of the table (and that is how we see him in Flatland) you would see nothing but a straight line.

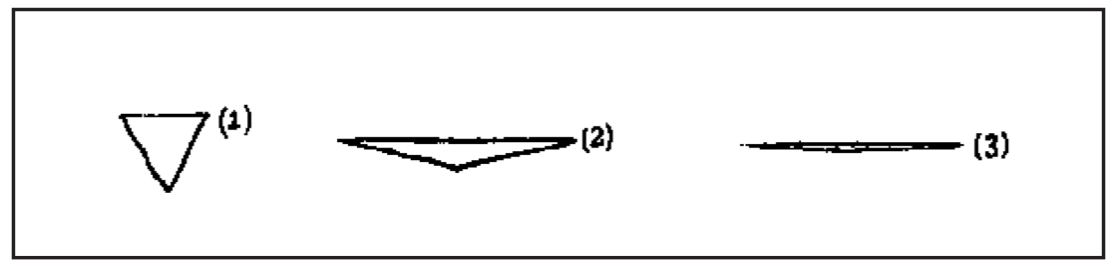


When I was in Spaceland I heard that your sailors have very similar experiences while they traverse your seas and discern some distant island or coast lying on the horizon. The far-off land may havhe bays, forelands, angles in and out to any number and extent; yet at a distance you see none of these (unless indeed your sun shines bright upon them revealing the projections and retirements by means of light and shade), nothing but a grey unbroken line upon the water.

Well, that is just what we see when one of our triangular or other acquaintances comes toward us in Flatland. As there is neither sun with us, nor any light of such a kind as to make shadows, we have none of the helps to the sight that you have in Spaceland. If our friend comes closer to us we see his line becomes larger; if he leaves us it becomes smaller: but still he looks like a straight line; be he a Triangle, Square, Pentagon, Hexagon, Circle, what you will - a straight Line he looks and nothing else. You may perhaps ask how under these disadvantageous circumstances we are able to distinguish our friends from one another: but the answer to this very natural question will be more fitly and easily given when I come to describe the inhabitants of Flatland. For the present let me defer this subject, and say a word or two about the climate and houses in our country.

\section{Of the Climate and Houses in Flatland}

AS WITH you, so also with us, there are four points of the compass North, South, East, and West. There being no sun nor other heavenly bodies, it is impossible for us to determine the North in the usual way; but we have a method of our own. By a Law of Nature with us, there is a constant attraction to the South; and, although in temperate climates this is very slight - so that even a Woman in reasonable health can journey several furlongs northward without much difficulty - yet the hampering effect of the southward attraction is quite sufficient to serve as a compass in most parts of our earth. Moreover, the rain (which falls at stated intervals) coming always from the North, is an additional assistance; and in the towns we have the guidance of the houses, which of course have their sidewalls running for The most part 
North and South, so that the roofs may keep off the rain from the North. In the country, where there are no houses, the trunks of the trees serve as some sort of guide. Altogether, we have not so much difficulty as might be expected in determining our bearings.

Yet in our more temperate regions, in which the southward attraction is hardly felt, walking sometimes in a perfectly desolate plain where there have been no houses nor trees to guide me, I have been occasionally compelled to remain stationary for hours together, waiting till the rain came before continuing my journey. On the weak and aged, and especially on delicate Females, the force of attraction tells much more heavily than on the robust of the Male Sex, so that it is a point of breeding, if you meet a Lady in the street, always to give her the North side of the way - by no means an easy thing to do always at short notice when you are in rude health and in a climate where it is difficult to tell your North from your South. Windows there are none in our houses: for the light comes to us alike in our homes and out of them, by day and by night, equally at all times and in all places, whence we know not. It was in old days, with our learned men, an interesting and oft-investigated question, "What is the origin of light?" and the solution of it has been repeatedly attempted, with no other result than to crowd our lunatic asylums with the would-be solvers. Hence, after fruitless attempts to suppress such investigations indirectly by making them liable to a heavy tax, the Legislature, in comparatively recent times, absolutely prohibited them. I - alas; I alone in Flatland - know now only too well the true solution of this mysterious problem; but my knowledge cannot be made intelligible to a single one of my countrymen; and I am mocked at - I, the sole possessor of the truths of Space and of the theory of the introduction of Light from the world of three Dimensions - as if I were the maddest of the mad! But a truce to these painful digressions: let me return to our houses.

The most common form for the construction of a house is five-sided or pentagonal, as in the annexed figure. The two Northern sides RO, OF, constitute the roof, and for the most 
part have no doors; on the East is a small door for the Women; on the West a much larger one for the Men; the South side or floor is usually doorless.

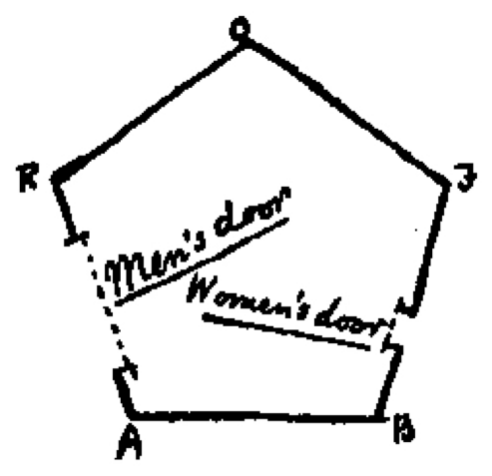

Square and triangular houses are not allowed, and for this reason. The angles of a Square (and still more those of an equilateral Triangle,) being much more pointed than those of a Pentagon, and the lines of inanimate objects (such as houses) being dimmer than the lines of Men and Women, it follows that there is no little danger lest the points of a square or triangular house residence might do serious injury to an inconsiderate or perhaps absent-minded traveller suddenly therefore, running against them: and as early as the eleventh century of our era, triangular houses were universally forbidden by Law, the only exceptions being fortifications, powder-magazines, barracks, and other state buildings, which it is not desirable that the general public should approach without circumspection.

At this period, square houses were still everywhere permitted, though discouraged by a special tax. But, about three centuries afterwards, the Law decided that in all towns containing a population above ten thousand, the angle of a Pentagon was the smallest house-angle that could be allowed consistently with the public safety. The good sense of the community has seconded the efforts of the Legislature; and now, even in the country, the pentagonal construction has superseded every other. It is only now and then in some very remote and backward agricultural district that an antiquarian may still discover a square house. 


\section{Concerning the Inhabitants of Flatland}

THE GREATEST length or breadth of a full grown inhabitant of Flatland may be estimated at about eleven of your inches. Twelve inches may be regarded as a maximum.

Our Women are Straight Lines.

Our Soldiers and Lowest Classes of Workmen are Triangles with two equal sides, each about eleven inches long, and a base or third side so short (often not exceeding half an inch) that they form at their vertices a very sharp and formidable angle. Indeed when their bases are of the most degraded type (not more than the eighth part of an inch in size). they can hardly be distinguished from Straight Lines or Women; so extremely pointed are their vertices. With us, as with you, these Triangles are distinguished from others by being called Isosceles; and by this name I shall refer to them in the following pages.

Our Middle Class consists of Equilateral or Equal-Sided Triangles.

Our Professional Men and Gentlemen are Squares (to which class I myself belong) and Five-Sided Figures or Pentagons.

Next above these come the Nobility, of whom there are several degrees, beginning at Six-Sided Figures, or Hexagons, and from thence rising in the number of their sides till they receive the honourable title of Polygonal, or many-sided. Finally when the number of the sides becomes so numerous, and the sides themselves so small, that the figure cannot be distinguished from a circle, he is included in the Circular or Priestly order; and this is the highest class of all.

It is a Law of Nature with us that a male child shall have one more side than his, father, so that each generation shall rise (as a rule) one step in the scale of development and nobility. Thus the son of a Square is a Pentagon; the son of a Pentagon, a Hexagon; and so on.

But this rule applies not always to the Tradesmen, and still less often to the Soldiers, and to the Workmen; who indeed can hardly be said to deserve the name of human Figures, since they have not all their sides equal. With them therefore the Law of Nature does not hold; and the son of an Isosceles (i.e. a Triangle with two 
sides equal) remains Isosceles still. Nevertheless, all hope is not shut out, even from the Isosceles, that his posterity may ultimately rise above his degraded condition. For, after a long series of military successes, or diligent and skilful labours, it is generally found that the more intelligent among the Artisan and Soldier classes manifest a slight increase of their third side or base, and a shrinkage of the two other sides. Intermarriages (arranged by the Priests) between the sons and daughters of these more intellectual members of the lower classes generally result in an offspring approximating still more to the type of the Equal-Sided Triangle.

Rarely - in proportion to the vast numbers of Isosceles births - is a genuine and certifiable Equal-Sided Triangle produced from Isosceles parents. 2 Such a birth requires, as its antecedents, not only a series of carefully arranged intermarriages, but also a long, continued exercise of frugality and self-control on the part of the would-be ancestors of the coming Equilateral, and a patient, systematic, and continuous development of the Isosceles intellect through many generations.

The birth of, a True Equilateral Triangle from Isosceles parents is the subject of rejoicing in our country for many furlongs around. After a strict examination conducted by the Sanitary and Social Board, the infant, if certified as Regular, is with solemn ceremonial admitted into the class of Equilaterals. He is then immediately taken from his proud yet sorrowing parents and adopted by some childless Equilateral, who is bound by oath never to permit the child henceforth to enter his former home or so much as to look upon his relations again, for fear lest the freshly developed organism may, by force of unconscious imitation, fall back again into his hereditary level.

The occasional emergence of an Equilateral from the ranks of his serf-born ancestors is welcomed, not only by the poor serfs themselves, as a gleam of light and hope shed upon the monotonous squalor of their existence, but also by the Aristocracy at large; for all the higher classes are well aware that these rare phenomena, while they do little or nothing to vulgarize their own privileges, serve as a most useful barrier against revolution from below. 
Had the acute-angled rabble been all, without exception, absolutely destitute of hope and of ambition, they might have found leaders in some of their many seditious outbreaks, so able as to render their superior numbers and strength too much even for the wisdom of the Circles. But a wise ordinance of Nature has decreed that, in proportion as the working-classes increase in intelligence, knowledge, and all virtue, in that same proportion their acute angle (which makes them physically terrible) shall increase also and approximate to the comparatively harmless angle of the Equilateral Triangle. Thus, in the most brutal and formidable of the soldier class - creatures almost on a level with women in their lack of intelligence - it is found that, as they wax in the mental ability necessary to employ their tremendous penetrating power to advantage, so do they wane in the power of penetration itself.

How admirable is this Law of Compensation! And how perfect a proof of the natural fitness and, I may almost say, the divine origin of the aristocratic constitution of the States in Flatland! By a judicious use of this Law of Nature, the Polygons and Circles are almost always able to stifle sedition in its very cradle, taking advantage of the irrepressible and boundless hopefulness of the human mind. Art also comes to the aid of Law and Order. It is generally found possible - by a little artificial compression or expansion on the part of the State physicians - to make some of the more intelligent leaders of a rebellion perfectly Regular, and to admit them at once into the privileged classes; a much larger number, who are still below the standard, allured by the prospect of being ultimately ennobled, are induced to enter the State Hospitals, where they are kept in honourable confinement for life; one or two alone of the more obstinate, foolish, and hopelessly irregular are led to execution.

Then the wretched rabble of the Isosceles, planless and leaderless, are either transfixed without resistance by the small body of their brethren whom the Chief Circle keeps in pay for emergencies of this kind; or else more often, by means of jealousies and suspicions skilfully fomented among them by the Circular party, 
they are stirred to mutual warfare, and perish by one another's angles. No less than one hundred and twenty rebellions are recorded in our annals, besides minor outbreaks numbered at two hundred and thirty-five; and they have all ended thus.

\section{Concerning the Women.}

IF OUR highly pointed Triangles of the Soldier class are formidable, it may be readily inferred that far more formidable are our Women. For if a Soldier is a wedge, a Woman is a needle; being, so to speak, all point, at least at the two extremities. Add to this the power of making herself practically invisible at will, and you will perceive that a Female, in Flatland, is a creature by no means to be trifled with.

But here, perhaps, some of my younger Readers may ask how a woman in Flatland can make herself invisible. This ought, I think, to be apparent without any explanation. However, a few words will make it clear to the most unreflecting.

Place a needle on a table. Then, with your eye on the level of the table, look at it side-ways, and you see the whole length of it; but look at it end-ways, and you see nothing but a point, it has become practically invisible. Just so is it with one of our Women. When her side is turned towards us, we see her as a straight line; when the end containing her eye or mouth - for with us these two organs are identical - is the part that meets our eye, then we see nothing but a highly lustrous point; but when the back is presented to our view, then - being only sublustrous, and, indeed, almost as dim as an inanimate object - her hinder extremity serves her as a kind of Invisible Cap.

The dangers to which we are exposed from our Women must now be manifest to the meanest capacity in Spaceland. If even the angle of a respectable Triangle in the middle class is not without its dangers; if to run against a Working Man involves a gash; if collision with an officer of the military class necessitates a serious wound; if a mere touch from the vertex of a Private Soldier brings with it danger of death; - what can it be to run against a Woman, except absolute and immediate destruction? And when a Woman is invisible, or visible only as a dim sub- 
lustrous point, how difficult must it be, even for the most cautious, always to avoid collision!

Many are the enactments made at different times in the different States of Flatland, in order to minimize this peril; and in the Southern and less temperate climates where the force of gravitation is greater, and human beings more liable to casual and involuntary motions, the Laws concerning Women are naturally much more stringent. But a general view of the Code may be obtained from the following summary:

1. Every house shall have one entrance in the Eastern side, for the use of Females only; by which all females shall enter "in a becoming and respectful manner" 3 and not by the Men's or Western door.

2. No Female shall walk in any public place without continually keeping up her Peace-cry, under penalty of death.

3. Any Female, duly certified to be suffering from St. Vitus's Dance, fits, chronic cold accompanied by violent sneezing, or any disease necessitating involuntary motions, shall be instantly destroyed.

In some of the States there is an additional Law forbidding Females, under penalty of death, from walking or standing in any public place without moving their backs constantly from right to left so as to indicate their presence to those behind them; others oblige a Woman, when travelling, to be followed by one of her sons, or servants, or by her husband; others confine Women altogether to their houses except during the religious festivals. But it has been found by the wisest of our Circles or Statesmen that the multiplication of restrictions on Females tends not only to the debilitation and diminution of the race, but also to the increase of domestic murders to such an extent that a State loses more than it gains by a too prohibitive Code.

For whenever the temper of the Women is thus exasperated by confinement at home or hampering regulations abroad, they 
are apt to vent their spleen upon their husbands and children; and in the less temperate climates the whole male population of a village has been sometimes destroyed in one or two hours of simultaneous female outbreak. Hence the Three Laws, mentioned above, suffice for the better regulated States, and may be accepted as a rough exemplification of our Female Code.

After all, our principal safeguard is found, not in Legislature, but in the interests of the Women themselves. For, although they can inflict instantaneous death by a retrograde movement, yet unless they can at once disengage the irstinging extremity from the struggling body of their victim, their own frail bodies are liable to be shattered.

The power of Fashion is also on our side. I pointed out that in some less civilized States no female is suffered to stand in any public place without swaying her back from right to left. This practice has been universal among ladies of any pretensions to breeding in all well-governed States, as far back as the memory of Figures can reach. It is considered a disgrace to any State that legislation should have to enforce what ought to be, and is in every respectable female, a natural instinct. The rhythmical and, if I may so say, well-modulated undulation of the back in our ladies of Circular rank is envied and imitated by the wife of a common Equilateral, who can achieve nothing beyond a mere monotonous swing, like the ticking of a pendulum; and the regular tick of the Equilateral is no less admired and copied by the wife of the progressive and aspiring Isosceles, in the females of whose family no "back-motion" of any kind has become as yet a necessity of life. Hence, in every family of position and consideration, "back motion" is as prevalent as time itself; and the husbands and sons in these households enjoy immunity at least from invisible attacks.

Not that it must be for a moment supposed that our Women are destitute of affection. But unfortunately the passion of the moment predominates, in the Frail Sex, over every other consideration. This is, of course, a necessity arising from their unfortunate conformation. For as they have no pretensions to an angle, being inferior in this respect to the very lowest of the 
Isosceles, they are consequently wholly devoid of brain-power, and have neither reflection, judgment nor forethought, and hardly any memory. Hence, in their fits of fury, they remember no claims and recognize no distinctions. I have actually known a case where a Woman has exterminated her whole household, and half an hour afterwards, when her rage was over and the fragments swept away, has asked what has become of her husband and her children.

Obviously then a Woman is not to be irritated as long as she is in a position where she can turn round. When you have them in their apartments - which are constructed with a view to denying them that power - you can say and do what you like; for they are then wholly impotent for mischief, and will not remember a few minutes hence the incident for which they may be at this moment threatening you with death, nor the promises which you may have found it necessary to make in order to pacify their fury.

On the whole we get on pretty smoothly in our domestic relations, except in the lower strata of the Military Classes. There the want of tact and discretion on the part of the husbands produces at times indescribable disasters. Relying too much on the offensive weapons of their acute angles instead of the defensive organs of good sense and seasonable simulations, these reckless creatures too often neglect the prescribed construction of the women's apartments, or irritate their wives by ill-advised expressions out of doors, which they refuse immediately to retract. Moreover a blunt and stolid regard for literal truth indisposes them to make those lavish promises by which the more judicious Circle can in a moment pacify his consort. The result is massacre; not, however, without its advantages, as it eliminates the more brutal and troublesome of the Isosceles; and by many of our Circles the destructiveness of the Thinner Sex is regarded as one among many providential arrangements for suppressing redundant population, and nipping Revolution in the bud.

Yet even in our best regulated and most approximately Circular families I cannot say that the ideal of family life is so high as with you in Spaceland. There is peace, in so far as the 
absence of slaughter may be called by that name, but there is necessarily little harmony of tastes or pursuits; and the cautious wisdom of the Circles has ensured safety at the cost of domestic comfort. In every Circular or Polygonal household it has been a habit from time immemorial - and now has become a kind of instinct among the women of our higher classes - that the mothers and daughters should constantly keep their eyes and mouths towards their husband and his male friends; and for a lady in a family of distinction to turn her back upon her husband would be regarded as a kind of portent, involving loss of status. But, as I shall soon shew, this custom, though it has the advantage of safety, is not without its disadvantages.

In the house of the Working Man or respectable Tradesman - where the wife is allowed to turn her back upon her husband, while pursuing her household avocations - there are at least intervals of quiet, when the wife is neither seen nor heard, except for the humming sound of the continuous Peace-cry; but in the homes of the upper classes there is too often no peace. There the voluble mouth and bright penetrating eye are ever directed to wards the Master of the household; and light itself is not more persistent than the stream of feminine discourse. The tact and skill which suffice to avert a Woman's sting are unequal to the task of stopping a Woman's mouth; and as the wife has absolutely nothing to say, and absolutely no constraint of wit, sense, or conscience to prevent her from saying it, not a few cynics have been found to aver that they prefer the danger of the death-dealing but inaudible sting to the safe sonorousness of a Woman's other end.

To my readers in Spaceland the condition of our Women may seem truly deplorable, and so indeed it is. A Male of the lowest type of the Isosceles may look forward to some improvement of his angle, and to the ultimate elevation of the whole of his degraded caste; but no Woman can entertain such hopes for her sex. "Once a Woman, always a Woman" is a Decree of Nature; and the very Laws of Evolution seem suspended in her disfavour. Yet at least we can admire the wise Prearrangement which has ordained that, as they have no hopes, so they shall have no 
memory to recall, and no forethought to anticipate, the miseries and humiliations which are at once a necessity of their existence and the basis of the constitution of Flatland.

\section{Of our Methods of Recognizing one another.}

YOU, WHO are blessed with shade as well as light, you, who are gifted with two eyes, endowed with a knowledge of perspective, and charmed with the enjoyment of various colours, you, who can actually see an angle, and contemplate the complete circumference of a Circle in the happy region of the Three Dimensions - how shall I make clear to you the extreme difficulty which we in Flatland experience in recognizing one another's configuration?

Recall what I told you above. All beings in Flatland, animate or inanimate, no matter what their form, present to our view the same, or nearly the same, appearance, viz. that of a straight Line. How then can one be distinguished from another, where all appear the same?

The answer is threefold. The first means of recognition is the sense of hearing; which with us is far more highly developed than with you, and which enables us not only to distinguish by the voice our personal friends, but even to discriminate between different classes, at least so far as concerns the three lowest orders, the Equilateral, the Square, and the Pentagon - for of the Isosceles I take no account. But as we ascend in the social scale, the process of discriminating and being discriminated by hearing increases in difficulty, partly because voices are assimilated, partly because the faculty of voicediscrimination is a plebeian virtue not much developed among the Aristocracy. And wherever there is any danger of imposture we cannot trust to this method. Amongst our lowest orders, the vocal organs are developed to a degree more than correspondent with those of hearing, so that an Isosceles can easily feign the voice of a Polygon, and, with some training, that of a Circle himself. A second method is therefore more commonly resorted to.

Feeling is, among our Women and lower classes - about our upper classes I shall speak presently - the principal test of recognition, at all events between strangers, and when the question 
is, not as to the individual, but as to the class. What therefore "introduction" is among the higher classes in Spaceland, that the process of "feeling" is with us. "Permit me to ask you to feel and be felt by my friend Mr. So-and-so" - is still, among the more old- fashioned of our country gentlemen in districts remote from towns, the customary formula for a Flatland introduction. But in the towns, and among men of business, the words "be felt by" are omitted and the sentence is abbreviated to, "Let me ask you to feel Mr. So-and-so"; although it is assumed, of course, that the "feeling" is to be reciprocal. Among our still more modern and dashing young gentlemen - who are extremely averse to superfluous effort and supremely indifferent to the purity of their native language - the formula is still further curtailed by the use of "to feel" in a technical sense, meaning, "to recommend-for-the-purposes-offeeling-and-being-felt"; and at this moment the "slang" of polite or fast society in the upper classes sanctions such a barbarism as "Mr. Smith, permit me to feel Mr. Jones."

Let not my Reader however suppose that "feeling" is with us the tedious process that it would be with you, or that we find it necessary to feel right round all the sides of every individual before we determine the class to which he belongs. Long practice and training, begun in the schools and continued in the experience of daily life, enable us to discriminate at once by the sense of touch, between the angles of an equal-sided Triangle, Square, and Pentagon; and I need not say that the brainless vertex of an acute angled Isosceles is obvious to the dullest touch. It is therefore not necessary, as a rule, to do more than feel a single angle of an individual; and this, once ascertained, tells us the class of the person whom we are addressing, unless indeed he belongs to the higher sections of the nobility. There the difficulty is much greater. Even a Master of Arts in our University of Wentbridge has been known to confuse a ten-sided with a twelve-sided Polygon; and there is hardly a Doctor of Science in or out of that famous University who could pretend to decide promptly and unhesitatingly between a twenty-sided and a twenty-four sided member of the Aristocracy. 
Those of my readers who recall the extracts I gave above from the Legislative code concerning Women, will readily perceive that the process of introduction by contact requires some care and discretion. Otherwise the angles might inflict on the unwary Feeler irreparable injury. It is essential for the safety of the Feeler that the Felt should stand perfectly still. A start, a fidgety shifting of the position, yes, even a violent sneeze, has been known before now to prove fatal to the incautious, and to nip in the bud many a promising friendship. Especially is this true among the lower classes of the Triangles. With them, the eye is situated so far from their vertex that they can scarcely take cognizance of what goes on at that extremity of their frame. They are, moreover, of a rough coarse nature, not sensitive to the delicate touch of the highly organized Polygon. What wonder then if an involuntary toss of the head has ere now deprived the State of a valuable life!

I have heard that my excellent Grandfather - one of the least irregular of his unhappy Isosceles class, who indeed obtained, shortly before his decease, four out of seven votes from the Sanitary and Social Board for passing him into the class of the Equal-sided - often deplored, with a tear in his venerable eye, a miscarriage of this kind, which had occurred to his great-greatgreat-Grandfather, a respectable Working Man with an angle or brain of $59^{\circ} 30^{\prime}$. According to his account, my unfortunate Ancestor, being afflicted with rheumatism, and in the act of being felt by a Polygon, by one sudden start accidentally transfixed the Great Man through the diagonal; and thereby, partly in consequence of his long imprisonment and degradation, and partly because of the moral shock which pervaded the whole of my Ancestor's relations, threw back our family a degree and a half in their ascent towards better things. The result was that in the next generation the family brain was registered at only $58^{\circ}$, and not till the lapse of five generations was the lost ground recovered, the full $60^{\circ}$ attained, and the Ascent from the Isosceles finally achieved. And all this series of calamities from one little accident in the process of Feeling.

At this point I think I hear some of my better educated read- 
ers exclaim, "How could you in Flatland know anything about angles and degrees, or minutes? We can see an angle, because we, in the region of Space, can see two straight lines inclined to one another; but you, who can see nothing but one straight line at a time, or at all events only a number of bits of straight lines all in one straight line - how can you ever discern any angle, and much less register angles of different sizes?"

I answer that though we cannot see angles, we can infer them, and this with great precision. Our sense of touch, stimulated by necessity, and developed by long training, enables us to distinguish angles far more accurately than your sense of sight, when unaided by a rule or measure of angles. Nor must I omit to explain that we have great natural helps. It is with us a Law of Nature that the brain of the Isosceles class shall begin at half a degree, or thirty minutes, and shall increase (if it increases at all) by half a degree in every generation; until the goal of $60^{\circ}$ is reached, when the condition of serfdom is quitted, and the freeman enters the class of Regulars.

Consequently, Nature herself supplies us with an ascending scale or Alphabet of angles for half a degree up to $60^{\circ}$, Specimens of which are placed in every Elementary School throughout the land. Owing to occasional retrogressions, to still more frequent moral and intellectual stagnation, and to the extraordinary fecundity of the Criminal and Vagabond Classes, there is always a vast superfluity of individuals of the half degree and single degree class, and a fair abundance of Specimens up to $10^{\circ}$. These are absolutely destitute of civic rights; and a great number of them, not having even intelligence enough for the purposes of warfare, are devoted by the States to the service of education. Fettered immovably so as to remove all possibility of danger, they are placed in the class rooms of our Infant Schools, and there they are utilized by the Board of Education for the purpose of imparting to the offspring of the Middle Classes that tact and intelligence of which these wretched creatures themselves are utterly devoid.

In some States the Specimens are occasionally fed and suffered to exist for several years; but in the more temperate and 
better regulated regions, it is found in the long run more advantageous for the educational interests of the young, to dispense with food, and to renew the Specimens every month - which is about the average duration of the foodless existence of the Criminal class. In the cheaper schools, what is gained by the longer existence of the Specimen is lost, partly in the expenditure for food, and partly in the diminished accuracy of the angles, which are impaired after a few weeks of constant "feeling." Nor must we forget to add, in enumerating the advantages of the more expensive system, that it tends, though slightly yet perceptibly, to the diminution of the redundant Isosceles population - an object which every statesman in Flatland constantly keeps in view. On the whole therefore - although I am not ignorant that, in many popularly elected School Boards, there is a reaction in favour of "the cheap system" as it is called - I am myself disposed to think that this is one of the many cases in which expense is the truest economy.

But I must not allow questions of School Board politics to divert me from my subject. Enough has been said, I trust, to shew that Recognition by Feeling is not so tedious or indecisive a process as might have been supposed; and it is obviously more trustworthy than Recognition by hearing. Still there remains, as has been pointed out above, the objection that this method is not without danger. For this reason many in the Middle and Lower classes, and all without exception in the Polygonal and Circular orders, prefer a third method, the description of which shall be reserved for the next section.

\section{Of Recognition by Sight}

I AM about to appear very inconsistent. In previous sections I have said that all figures in Flatland present the appearance of a straight line; and it was added or implied, that it is consequently impossible to distinguish by the visual organ between individuals of different classes: yet now I am about to explain to my Spaceland critics how we are able to recognize one another by the sense of sight.

If however the Reader will take the trouble to refer to the pas- 
sage in which Recognition by Feeling is stated to be universal, he will find this qualification - "among the lower classes." It is only among the higher classes and in our temperate climates that Sight Recognition is practised.

That this power exists in any regions and for any classes is the result of Fog; which prevails during the greater part of the year in all parts save the torrid zones. That which is with you in Spaceland an unmixed evil, blotting out the landscape, depressing the spirits, and enfeebling the health, is by us recognized as a blessing scarcely inferior to air itself, and as the Nurse of arts and Parent of sciences. But let me explain my meaning, without further eulogies on this beneficent Element.

If Fog were non-existent, all lines would appear equally and indistinguishably clear; and this is actually the case in those unhappy countries in which the atmosphere is perfectly dry and. transparent. But wherever there is a rich supply of Fog objects that are at a distance, say of three feet, are appreciably dimmer than those at a distance of two feet eleven inches; and the result is that by careful and constant experimental observation of comparative dimness and clearness, we are enabled to infer with great exactness the configuration of the object observed.

An instance will do more than a volume of generalities to make my meaning clear.

$[\ldots]$

\section{Part II: OTHER WORLDS}

"O brave new worlds, that have such people in them!"

\section{How I had a Vision of Lineland}

IT WAS the last day but one of the 1999th year of our era, and the first day of the Long Vacation. Having amused myself till a late hour with my favourite recreation of Geometry, I had retired to rest with an unsolved problem in my mind. In the night I had a dream. I saw before me a vast multitude of small Straight Lines (which I naturally assumed to be Women) interspersed with other Beings still smaller and of the nature of lustrous 
points - all moving to and fro in one and the same Straight Line, and, as nearly as I could judge, with the same velocity.

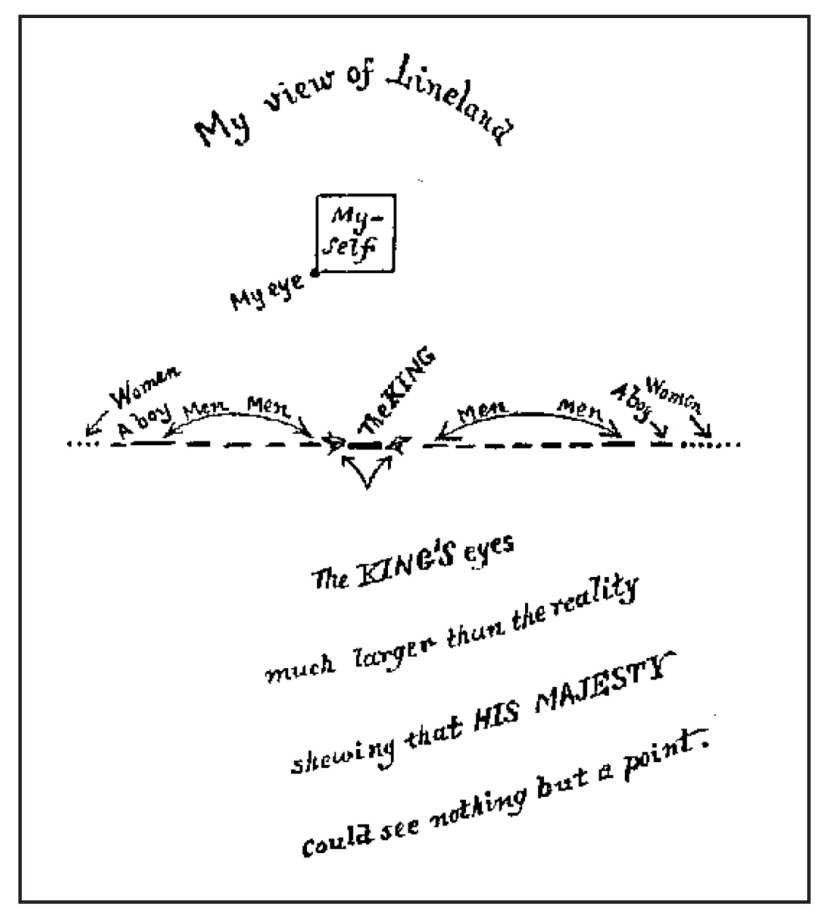

A noise of confused, multitudinous chirping or twittering issued from them at intervals as long as they were moving; but sometimes they ceased from motion, and then all was silence.

Approaching one of the largest of what I thought to be Women, I accosted her, but received no answer. A second and a third appeal on my part were equally ineffectual. Losing patience at what appeared to me intolerable rudeness, I brought my mouth into a position full in front of her mouth so as to intercept her motion, and loudly repeated my question, "Woman, what signifies this concourse, and this strange and confused chirping, and this monotonous motion to and fro in one and the same Straight Line?"

"I am no Woman," replied the small Line: "I am the Monarch of the world. But thou, whence intrudest thou into my realm 
of Lineland?" Receiving this abrupt reply, I begged pardon if I had in any way startled or molested his Royal Highness; and describing myself as a stranger I besought the King to give me some account of his dominions. But I had the greatest possible difficulty in obtaining any information on points that really interested me; for the Monarch could not refrain from constantly assuming that whatever was familiar to him must also be known to me and that I was simulating ignorance in jest. However, by persevering questions I elicited the following facts:

It seemed that this poor ignorant Monarch - as he called himself - was persuaded that the Straight Line which he called his Kingdom, and in which he passed his existence, constituted the whole of the world, and indeed the whole of Space. Not being able either to move or to see, save in his Straight Line, he had no conception of anything out of it. Though he had heard my voice when I first addressed him, the sounds had come to him in a manner so contrary to his experience that he had made no answer, "seeing no man," as he expressed it, "and hearing a voice as it were from my own intestines." Until the moment when I placed my mouth in his World, he had neither seen me, nor heard anything except confused sounds beating against - what I called his side, but what he called his inside or stomach; nor had he even now the least conception of the region from which I had come. Outside his World, or Line, all was a blank to him; nay, not even a blank, for a blank implies Space; say, rather, all was non existent.

His subjects - of whom the small Lines were men and the Points Women - were all alike confined in motion and eye-sight to that single Straight Line, which was their World. It need scarcely be added that the whole of their horizon was limited to a Point; nor would any one ever see anything but a Point. Man, woman, child, thing - each was a Point to the eye of a Linelander. Only by the sound of the voice could sex or age be distinguished. Moreover, as each individual occupied the whole of the narrow path, so to speak, which constituted his Universe, and no one could move to the right or left to make way for passers by, it followed that no Linelander could ever pass another. Once 
neighbours, always neighbours. Neighbourhood with them was like marriage with us. Neighbours remained neighbours, till death did them part.

Such a life, with all vision limited to a Point, and all motion to a Straight Line, seemed to me inexpressibly dreary; and I was surprised to note the vivacity and cheerfulness of the King. Wondering whether it was possible, amid circumstances so unfavourable to domestic relations, to enjoy the pleasures of conjugal union, I hesitated for some time to question his Royal Highness on so delicate a subject; but at last I plunged into it by abruptly inquiring as to the health of his family. "My wives and children," he replied, "are well and happy."

Staggered at this answer - for in the immediate proximity of the Monarch (as I had noted in my dream before I entered Lineland) there were none but Men - I ventured to reply, "Pardon me, but I cannot imagine how your Royal Highness can at any time either see or approach their Majesties, when there are at least half a dozen intervening individuals, whom you can neither see through, nor pass by? Is it possible that in Lineland proximity is not necessary for marriage and for the generation of children?"

"How can you ask so absurd a question?" replied the Monarch. "If it were indeed as you suggest, the Universe would soon be depopulated. No, no; neigbourhood is needless for the union of hearts; and the birth of children is too important a matter to have been allowed to depend upon such an accident as proximity. You cannot be ignorant of this. Yet since you are pleased to affect ignorance, I will instruct you as if you were the veriest baby in Lineland. Know, then, that marriages are consummated by means of the faculty of sound and the sense of hearing.

"You are of course aware that every Man has two mouths or voices - as well as two eyes - a bass at one and a tenor at the other of his extremities. I should not mention this, but that I have been unable to distinguish your tenor in the course of our conversation." I replied that I had but one voice, and that I had not been aware that his Royal Highness had two. "That confirms my impression," said the King, "that you are not a Man, 
but a feminine Monstrosity with a bass voice, and an utterly uneducated ear. But to continue.

"Nature having herself ordained that every Man should wed two wives - " "Why two?" asked I. "You carry your affected simplicity too far," he cried. "How can there be a completely harmonious union without the combination of the Four in One, viz. the Bass and Tenor of the Man and the Soprano and Contralto of the two Women?" "But supposing," said I, "that a man should prefer one wife or three?" "It is impossible," he said; "it is as inconceivable as that two and one should make five, or that the human eye should see a Straight Line." I would have interrupted him; but he proceeded as follows:

"Once in the middle of each week a Law of Nature compels us to move to and fro with a rhythmic motion of more than usual violence, which continues for the time you would take to count a hundred and one. In the midst of this choral dance, at the fiftyfirst pulsation, the inhabitants of the Universe pause in full career, and each individual sends forth his richest, fullest, sweetest strain. It is in this decisive moment that all our marriages are made. So exquisite is the adaptation of Bass to Treble, of Tenor to Contralto, that oftentimes the Loved Ones, though twenty thousand leagues away, recognize at once the responsive note of their destined Lover; and, penetrating the paltry obstacles of distance, Love unites the three. The marriage in that instant consummated results in a threefold Male and Female offspring which takes its place in Lineland."

"What! Always threefold?" said I. "Must one wife then always have twins?"

"Bass-voiced Monstrosity! yes," replied the King. "How else could the balance of the Sexes be maintained, if two girls were not born for every boy? Would you ignore the very Alphabet of Nature?" He ceased, speechless for fury; and some time elasped before I could induce him to resume his narrative.

"You will not, of course, suppose that every bachelor among us finds his mates at the first wooing in this universal Marriage Chorus. On the contrary, the process is by most of us many times repeated. Few are the hearts whose happy lot it is at once to 
recognize in each other's voices the partner intended for them by Providence, and to fly into a reciprocal and perfectly harmonious embrace. With most of us the courtship is of long duration. The Wooer's voices may perhaps accord with one of the future wives, but not with both; or not, at first, with either; or the Soprano and Contralto may not quite harmonize. In such cases Nature has provided that every weekly Chorus shall bring the three Lovers into closer harmony. Each trial of voice, each fresh discovery of discord, almost imperceptibly induces the less perfect to modify his or her vocal utterance so as to approximate to the more perfect. And after many trials and many approximations, the result is at last achieved. There comes a day at last, when, while the wonted Marriage Chorus goes forth from universal Lineland, the three far-off Lovers suddenly find themselves in exact harmony, and, before they are awake, the wedded Triplet is rapt vocally into a duplicate embrace; and Nature rejoices over one more marriage and over three more births." $[\ldots]$ 


\section{Excerpt from Flatland}

\section{Derek Beaulieu}

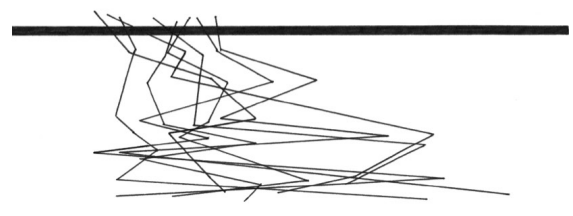



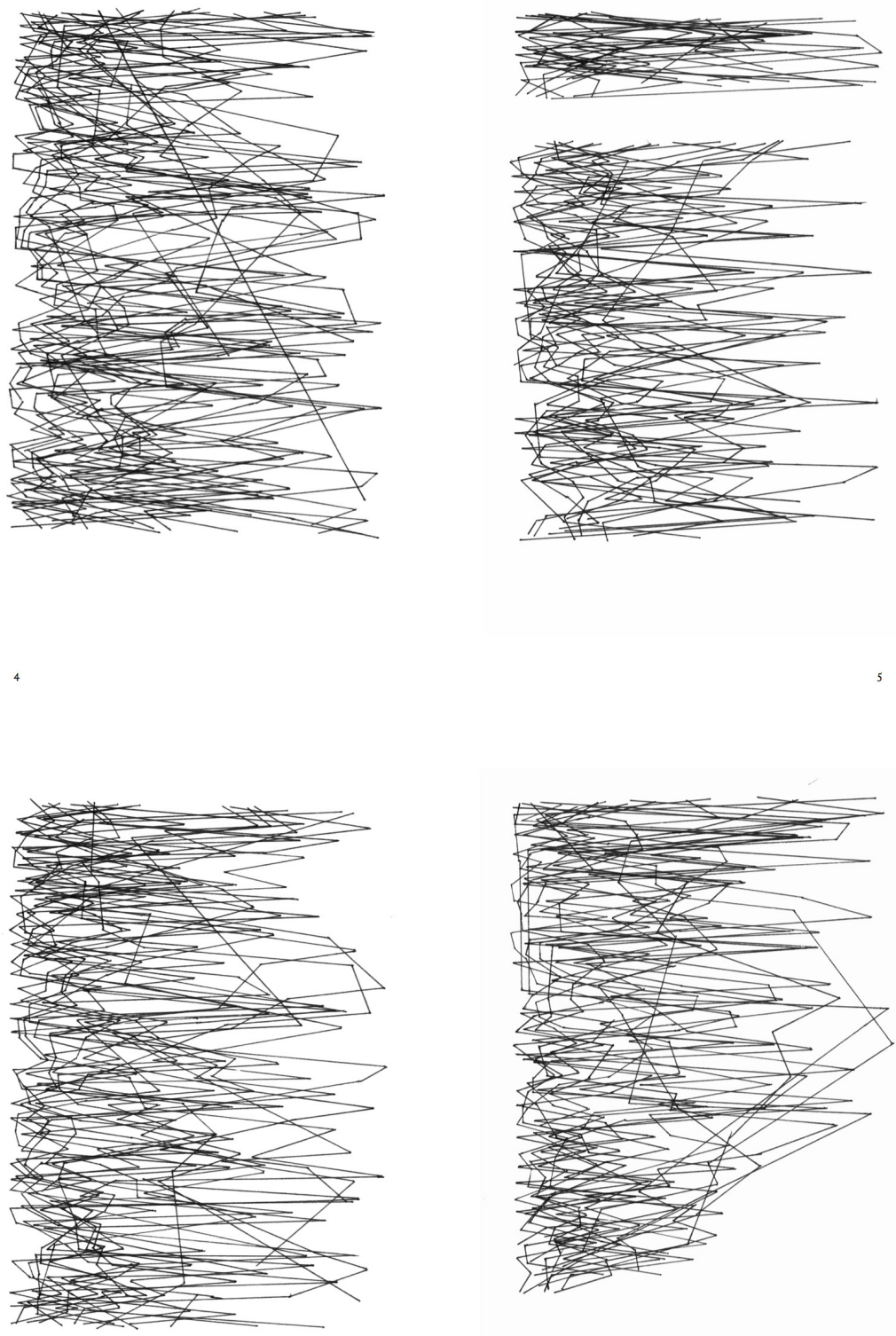

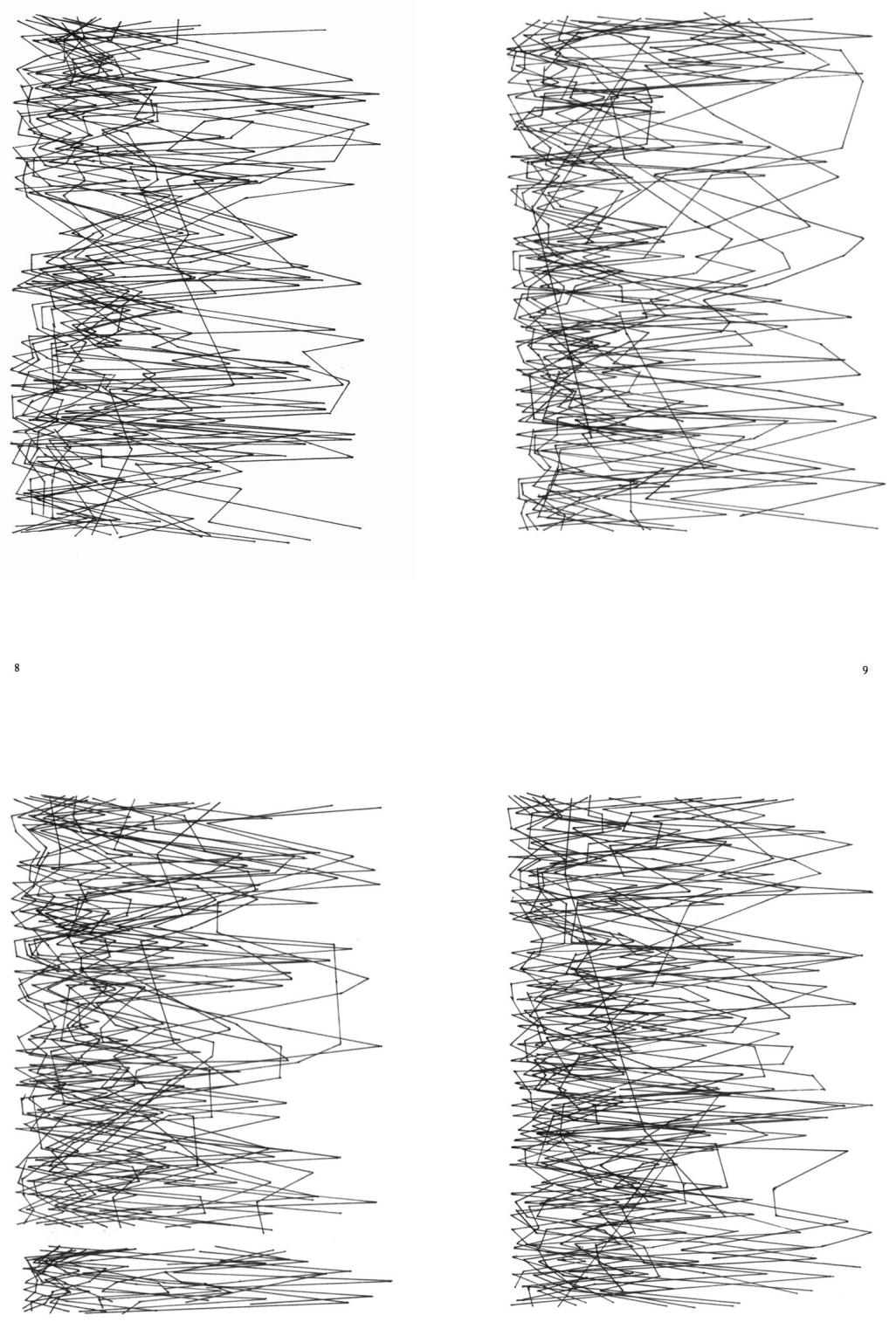

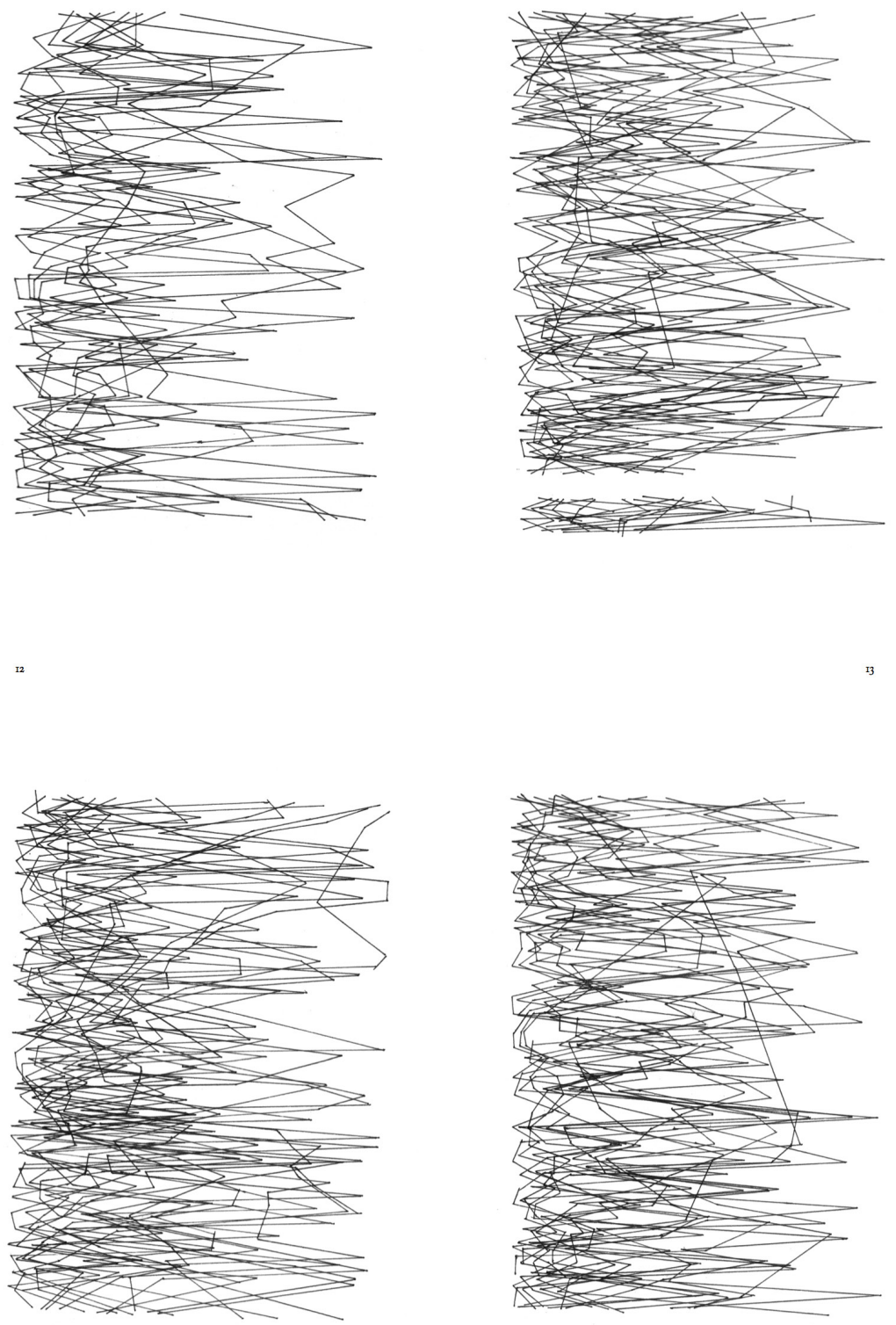

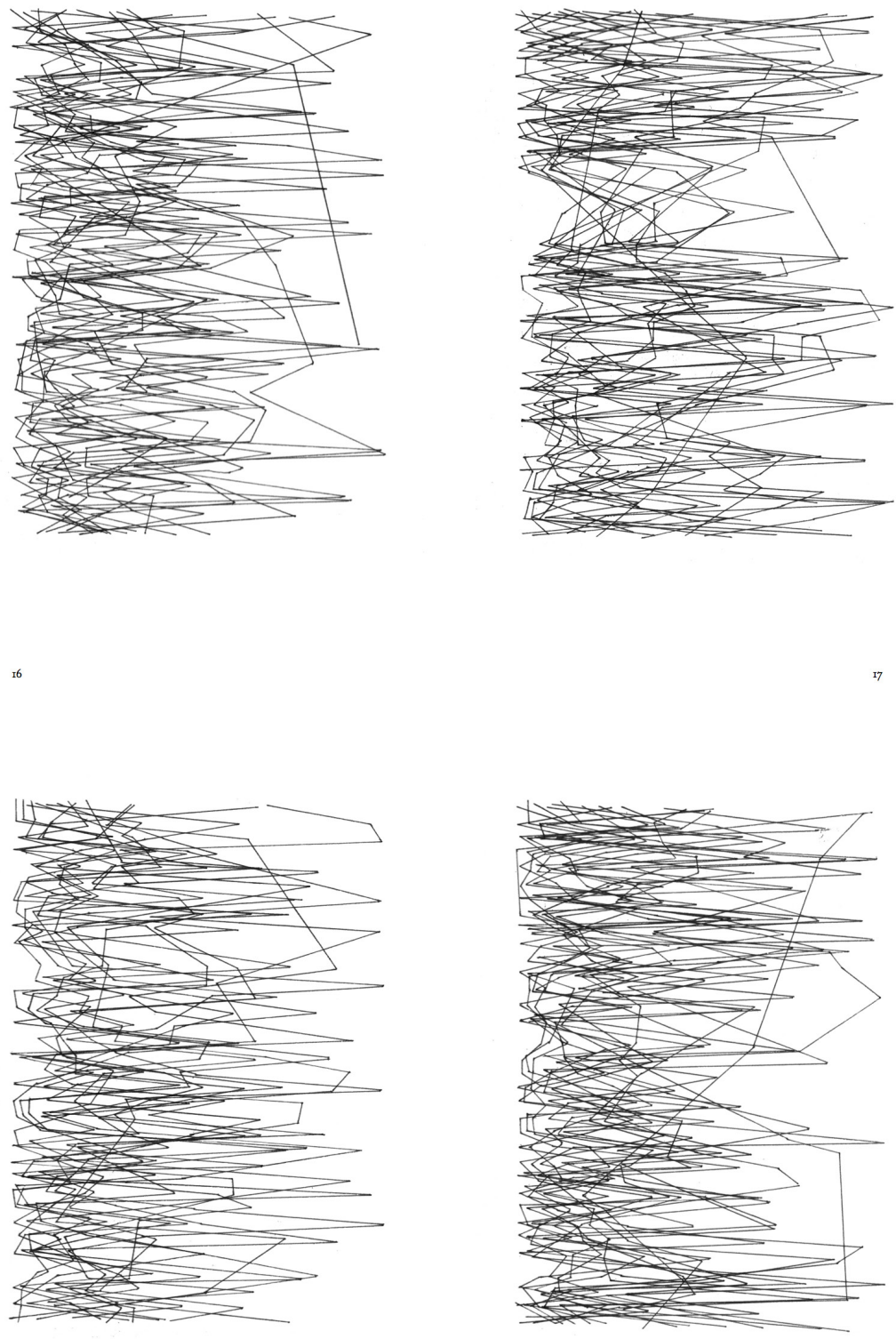



\section{Skywriting, Signals, and Poetry Systems \\ Jesper Olsson}

I.

Reading and literature have been crucial in the constructions of subjectivity during the modern era - within the framework of what Marshall McLuhan once called the Gutenberg Galaxy. However, with the advent of new technical media during the previous centuries, not only the space of literature, but also the configurations of an experiencing subject in time and space have been transformed and actively revised.

Here, I want to go back to the decades after World War II, and especially to the 1960 s, in order to discuss, briefly, how such reconfigurations were manifested in a set of artistic-poetic experiments. The overt aim is to historicize a contemporary media situation and to perhaps shed some light on the relation between, on the one hand, a current ideology of immediacy, transparency, and instant accessibility - circulating in a digital $24 / 7$-society - which tends to reproduce ideas of a solid subject in control and, on the other hand, the material and technical conditions 
for reading and experiencing today, which might subvert the notion of such a subject.

My approach can, methodologically, be described as media archaeological in its ambition to trace a genealogy of the present through detours in recent media history. This entails not just a story about media, however, but also an analysis of affect and meaning. And just as media archaeology often turn to art for input, I will, as mentioned, approach a handful of works from the sixties that employed new technology, even code and signals - the stuff of digital computing -, in their exploration of how media shape the space of literature.

\section{II.}

Most literature and art in the years after WWII was haunted haunted by the need to start anew, to move beyond a corrupt culture that had ended after two world wars. For many, technology became an asset in this endeavor. Radio, television, and even the awesome and futuristic computer was to be explored. Computer technology, moreover, arrived together with new theories of information, such as cybernetics, which not only challenged prevalent ideas of communication and knowledge, but also ontological demarcation lines between animal, man and machine, as well as established modes of representation.

Literature and art of course processed this in different ways - in everything from dystopian novels about the dissolution of the individual in sociotechnical systems, to an innovative use of new gadgets in the making of poetry. One of the most techsavvy, but also tech-critical genres to blossom during the period was sound poetry, which would be practiced in a large number of places - from Europe over North and South America to Japan and by a large number of poets, such as Bernard Heidsieck and Henri Chopin, Bob Cobbing and Lily Greenham, Ernst Jandl and Gerhard Rühm, Bengt Emil Johnson and Sten Hanson. Even if harking back to a long tradition of rhyming and chanting in poetry, the genre had a distinctly modern touch, finding its recent roots in nonsense verse, Futurism and Dada.

Still, it was to be radically rejuvenated in the postwar years 
due to the employment of sound recording and radio. The tape recorder, for instance, became a writing tool which made possible an expansion and differentiation of the acoustic space of literature. Not only the articulated voice, but a number of bodily and other sounds were incorporated into poetry through the affordances of the machine. Cut and splice and other editing techniques, but also the use of contact microphones and sophisticated placements of loudspeakers, paved the way for a different literary experience. Most notably, the space of literature, which previously had been constructed as an intimate sphere around the reader, now became diffuse and fluid.

Sound poetry produced a space for reading/listening in which you had to navigate and find your bearings. As Steven Connor has observed, we are never passive in relation to sound: "we never merely hear sound, we are always also listening to it, which is to say selecting certain significant sounds and isolating them from the background noise which continuously rumbles and rattles, continually on the qui vive for patterns of resemblance or recurrence" (Connor 2003). But the acoustic environments that surrounded the listener in sound poetry complicated such pattern-seeking, and invited an indeterminate and inter-sensorial activity. A complex space or ecology is created, in which we are immersed and which passes through us - but in no way firmly positions us as autonomous agents.

What sound poetry achieved was then an opening up of literature and poetry toward the spatial and material environments in which they take place. Even if immersion was sometimes a sought-for aesthetic effect, the body and the active configuration of a situated experience was more pertinent. One might say that not only did sound poetry open up literature; it also brought to the fore the absences, gaps, and in-betweens - temporal as well as spatial - that are always part of reading and writing and which makes mediation and media constitutive for experience as such, as John Durham Peters have suggested (Peters 2015:2). 


\section{III.}

Sound poetry would thus expose the seams in literature's cybernetic assemblage. And other experiments from the period would bring this exploration even one step further. In relation to the dissemination of cybernetics in the 1960s, many artistic and literary projects would investigate ideas about systems, media, and environments, while also attending to Marshall McLuhan's understanding of media as environments or ecologies. These ambitions can be connected to the contemporaneous tendency of displacing both the artwork and the traditional exhibition space through an investigation of its surroundings - in, for instance, system pieces by Hans Haacke or earth works by Robert Smithson.

Part of this aesthetics was also an interrogation of the standard roles and positions of artist and viewer. By seeking out and modifying places in nature, or by constructing artificial environments, other agential networks - including both humans and other-than-humans - were disclosed through such artworks. An example of the latter was the installation "Seek" (1969-1970) by The Archictecture Machine Group at M.I.T., described as "Life in a Computerized Environment" and presented at the important exhibition Software. Information technology: its new meaning for art (1970). While McLuhan in his analysis of media continued to place man at the center and considered media as his extensions, this artistic transformation of the subject-objectduo was more radical, and had more thoroughgoing aesthetic and political implications.

Since I want to focus on literature here, I will mention - briefly - a poetic project, which was directly connected to the works above, by its generic description as a "system" and by its partial presentation at the Software exhibition. The work in question is poet and Andy Warhol-collaborator John Giorno's Giorno Poetry Systems. The inception of this system was based on the idea - influenced by people such as John Cage and William Burroughs - of producing and distributing poetry by other means than paper, print, and books. In 1965, Giorno began to record and distribute poetry on LP-records. While packaging the art 
form anew, this did not in itself transform the space of literary experience in a drastic way.

In 1968, however, the concept was expanded by the inclusion of telephone technology into Giorno's system, through the NYbased project Dial-A-Poem. Giorno linked his poetry recordings to a telephone network - 15 lines with individual answering machines -, which people could call up in order to listen to a poem. Since much of the poetry was of its time - i.e. colored by countercultural ideas and issues -, many kids and teens called to hear the salacious details and dirty words, which stirred a public debate after some parents found out what was going on. Thus, apart from re-configuring the geomedial infrastructure of literature and producing new spaces for literary experience - the public phone booth was just one such environment -, Dial-APoem also affected the social and political ecology of literature, as poetry reached new readers in new ways.

Most importantly, however, and this was even more pronounced in Guerilla Radio, which Giorno installed at the Software exhibition in 1970, the system exposed the media technological conditions for the aesthetic experience of the work. At the show Giorno had substituted telephones for radio and broadcasted poetry on the AM band. The material and judicial conditions were (parodically) underlined in the catalogue text: "Under FCC Low Power Transmission Regulations, it is legal to broadcast on the AM band without a license, if one transmits with 100 milliwatts or less power in a free space, not interfering with licensed stations, and have a 12 foot antenna or use carriercurrent transmission" - and so on.

\section{IV.}

Work such as Giorno's explored - aesthetically - the media infrastructure of not only artistic practice, but, of phenomenological space and experience as well. More specifically, this infrastructure was exposed as the product of electric signals and the material means of transmitting them. The same can be observed in sound poetry, which actually practices and performs a "signaletic poetics". Thus, both can be said to prefigure a media condition of today. 
In the last work I will take a look at here - which has also given this article its title - the history of such a signaletic materiality is outlined, at the same time as its aesthetic potentials are imagined in inventive ways. The work in question is a piece by the Swedish poet and artist Åke Hodell called Skywriting and subtitled "Experiment with Electronisms". The text-and-image piece was published in the experimental Swedish art and media journal Gorilla in 1967. Partly a comment on earlier literary activities of Hodell, from the 1940 s and onward, the piece also contains poems and reflections on art, technology, LSD, and Zen as well as distorted photographs and collages. Moreover, the final part of Skywriting contains a score for an actual experiment with an airplane as the tool for production of poetic texts in the sky - a score that was meant to be performed at a festival of art and technology in Stockholm in 1966 called Visions of the Now.

The poems and reflections in Hodell's piece are quite interesting in relation to the context of media, infrastructure, and experience being explored in this article. They revolve around the various ways in which human experience has been displaced with the emergence of new technology during the 20 th century. Being a former pilot himself, Hodell is especially attuned to the mediation of experience in the cockpit of an aircraft, symbolized by the meters and instruments that are partly to be read, partly to be just reacted upon within a signal-feedback-system, which regulates the pilot's relation to space and earth. It was also this biographical experience that propelled Hodell to start writing what he called "electronisms" in the early 1950s, i.e. language intermingled - or as Katherine Hayles would have it, "intermediated" (Hayles 2005: 15-17) - with code. After reading McLuhan in the early 1960s, Hodell would define his electronisms accordingly (my translation):

extensions (expansions) of the sense organs through e.g. radar antennae and TV-cameras // transmutation of the technical "sense data" through electric amplification and fusion on electronic screens with maps unpredictable simultaneous visual-audial chains of events combined with blips, invisible rays hit the viewer in unused nerve 
centers and de-couple indoctrinated functional patterns ... the electrical voltages become so highly frequent that they collide with each other, it leads to electric satori ...

(Åke Hodell, “Skywriting”, Gorilla 2, 1967: 4)

This somewhat cryptic description points, on the one hand, to how the poetic mixture of code and language, image and text, electric signal and sound (in Hodell's sound poems) allegorizes the inescapable conditioning of experience by media technologies. On the other hand, it tries to incorporate the effects of this within a postindustrial information society characterized by a complex and manifold media ecology - of visual and acoustic as well as computational technologies -, which also, as we have seen, constructs new environments for literature and literary experience. This becomes emphasized in the planned Skywriting-performance, which includes not only the aircraft and its smoke-based text, but also radio signal transmissions from the plane to computers with screens placed in the festival area on the ground, and intended to be read and interpreted by the audience.

Hodell's work, consequently and explicitly, makes manifest a new media ecology for literary practice during the postwar decades. This entails not only a reconfiguration of the subject in order to present a more complex environment of agencies and forces, but also challenges the borderlines between nature and culture - which the first parable in Skywriting, about the sounds of an aircraft and a bumblebee, shows in a humorous way. It is an ecology of humans, animals, machines, and other entities that must be understood in relation to cybernetics and the emergent technologies of the postwar era.

V.

In a recently published book, the German media theorist Erich Hörl presents and outlines the concept of a "general ecology", indicating, as he writes, "a breakthrough of a new historical semantics" (Hörl 2017: 1). With this breakthrough, the concept 
of "ecology" has become "increasingly denaturalized" - an ecology without nature, to speak with Timothy Morton (2009). At the same time, it has gotten rid of a set of restricting political connotations - "dogmas of proximity and immediacy; of the familiar and of kinship" (Hörl, 2017: 1). And not least, "dogmas of authenticity", to quote Hörl again (2017: 2).

Such dogmas and ideas were crucial for the conceptualization and understanding of reading in the Gutenberg Galaxy - the space of literature was intimate and marked by proximity and immediacy between written word and reader. In a related manner, the modern subject was built and consolidated through such concepts and ideas, as is well-known from the critique directed at such notions by Derrida and others. However, such connections are more severely damaged through the multiplication and expansion of ecologies today - in a general ecology it becomes obvious how nature and culture, man and machine, artefactual and organic, are always already intermingled.

But if this expansion has become imminent in cultural and media theory today, its aesthetic and poetic exploration began quite some time ago - and historically and materially it is linked to the poetic activities from the postwar period addressed here; an observation that is corroborated, for instance, in Siegfried Zielinski's investigations in [...] nach den Medien (2011). If literature was once - and still often is - considered and experienced as an intimate bonding of book and reader, it has for half a century also focused on and explored the medial and material inbetweens in the space between reader and book. 


\section{Literature:}

Connor, Steven, "Ears Have Walls: On Hearing Art" (2003). URL: www. stevenconnor.com/earshavewalls.

Hayles, N. Katherine, My Mother Was a Computer. Digital Subjects and Literary Texts (University of Chicago Press 2005)

Hodell, Åke, "Skywriting”, Gorilla 2, 1967.

Hörl, Erich (ed.), General Ecology (Bloomsbury Academic 2017).

Morton, Timothy, Ecology Without Nature (Harvard University Press 2009).

Peters, John Durham, The Marvelous Clouds. Toward a Philosophy of Elemental Media (University of Chicago Press 2015).

Software. Information technology: its new meaning for art (Catalogue Jewish Museum, Brooklyn, NY 1970).

Zielinski, Siegfried, [...] nach den Medien (Merve Verlag 2011). 



\section{The End of Progress on Earth}

\section{Solveig Daugaard}

There are several analogies between innovations in communication technology and innovations in transportation technology in early media theory. This is no surprise since means of transportation and communication in the history of civilization has been completely entangled. In the chapter "Roads and Paper Routes" of Understanding Media (1964) Marshall McLuhan recounts how the Roman Empire triumphed over the Greek city states and village communities due to a convergence of innovations in transportation technology: the establishing of roads trafficked by horse carriages - and in communication media: the development of written, paper borne messages that could travel over much larger distances than before via the roads, that all lead, as we know, to Rome.

In terms of their conceptual history, the two things are tied even closer, since the term communication has been used in connection with roads, rivers and canals, long before becoming a term for information traffic. In the above mentioned chapter, McLuhan writes: 
In this book, we are concerned with all forms of transport of goods and information, both as metaphor and exchange. Each form of transport not only carries, but translates and transforms, the sender, the receiver, and the message. ${ }^{1}$

In McLuhan's conception, means of transport simply are media as he considers all technologies as media, or "extensions of man" - that is extensions of "our physical and nervous systems to increase power and speed." 2 Due to the increase of speed that came with road transport and paper messages, new communities were formed and new power structures were established that changed the entire ecology of civilization.

Quite a few years before McLuhan and his associates started working on media theory the American poet Gertrude Stein was going down a somewhat similar road. In her reflective, art critical essay Picasso (1938), about the work of her most famous painter friend, she writes:

the composition of each epoch depends upon the way the frequented roads are frequented, people remain the same, the way their roads are frequented is what changes from one century to another and it is that that makes the composition that is before the eyes of every one of that generation and it is that that makes the composition that a creator creates. ${ }^{3}$

In the following, I want to investigate how Stein's ideas of transport, composition and creation were shaped by her concrete experiences with the automobile and the airplane, the two major transport innovations of her time, both of which became significant metaphors in the conceptualization of her poetics as it was reformulated in the last decades of her life.

To unpack the quote just a little: "Composition" was Stein's preferred concept covering both the entire structure of daily life

1 Marshall McLuhan, Understanding Media. The Extensions of Man, London: Routledge 2001 (1964), p. 97-98.

2 Ibid., p. 98.

3 Gertrude Stein, Picasso. In: Writings 1932-1946, New York: Library of America 1998, p. 504. 
in an epoch, and the creative activities of the artist in this same epoch. It is more of a structural functionality than a category to describe a particular limited set of phenomena - and in this way, it somewhat resembles McLuhan's expansive concept of media. To Stein, the job of the artist was to articulate the changes in the composition of an epoch that were already there, but passed unnoticed for everyone else. As she proceeds in Picasso:

I very well remember at the beginning of the war being with Picasso on the boulevard Raspail when the first camouflaged truck passed. It was night, we had heard of camouflage but we had not yet seen it and Picasso amazed looked at it and then cried out, yes it is we who made it, that is cubism. ${ }^{4}$

Stein goes on to explain how in fact the composition of the first world war 1914-18 is "not one in which one man is in the center surrounded by a lot of other men," but a decentered composition "of which one corner was as important as another corner", in fact the composition of cubism.

Be that as it may, in 1915 Gertrude Stein and her partner Alice Toklas felt a need to flea for some time from the troubles of the war, cubist or not, and left their Paris studio for Palma de Mallorca, helped along by their friend the American painter William Cook and his wife, who had already lived on the island for some time. In spring 1917, after the battle of Verdun, they decided to go back to Paris. In The Autobiography of Alice B Toklas (1933), Stein's prank autobiography written in the voice of her companion, the narrator, Alice, accounts:

When it was all over [i.e. the battle of Verdun] we none of us wanted to stay in Mallorca any longer, we all wanted to go home. It was at this time that Cook and Gertrude Stein spent all their time talking about automobiles. They neither of them had driven but they were getting very interested. ${ }^{6}$

4 ibid.

5 Ibid., p. 504-505.

6 Gertrude Stein, The Autobiography of Alice B. Toklas. In: Writings 1903-1932, New York: Library of America 1998, p. 824. 
When Gertrude and Alice returned to Paris after a detour over Madrid, Cook had already realized his plans and was driving a Paris taxi to supplement his modest income as a painter. Back in a less troubled version of war-time Paris, Gertrude and Alice decided to get into the war and do their part. They managed to get a Ford car sent from Stein's cousin in America, and while they were waiting for it, William Cook taught Gertrude Stein how to drive his taxi. The two women soon started driving supplies to French hospitals around the country side for the organization The American Funds for French Wounded.

Stein and Toklas got rather attached to the car which they named "Auntie". More importantly, for my current purposes, driving also effectuated a change in Stein's experience of "the way the frequented roads were frequented" and thus suggested to her, that a new composition was in store. The automobile after this point became a crucial metaphor for Stein in her conceptualization of "the modern composition." In the lecture "Portraits and Repetition" written for her American lecture tour in 1934 she writes about the relation between modernity and movement: "the strange thing about the realization of existence is that like a train moving there is no real realization of it moving if it does not move against something and so that is what a generation does it shows that moving is existing." 7

According to Stein, this commonsense version of the principle of relativity became challenged in 20 th century America, where the importance of remembering previous generations in order to feel the progression of history had decreased:

[...] if the movement, that is any movement, is lively enough, perhaps it is possible to know that it is moving even if it is not moving against anything. And so in a way the American way has been not to need that generations are existing. ${ }^{8}$

7 Gertrude Stein, Lectures in America. In: Writings 1932-1946, New York: Library of America 1998, p. 287.

8 ibid. 
Here, Stein used the car to explain her idea of how this new condition was possible, where a new generation was not ahead of their own time, but moving so intensely in the middle of it that all context became irrelevant.

A motor goes inside of an automobile and the car goes. In short, this generation has conceived an intensity of movement so great that it has not to be seen against something else to be known, and therefore, this generation does not connect itself to anything, that is what makes this generation what it is and that is why it is American, $(\ldots) .9$

In Stein's conception in 1934 the ultimate sense of progress is closely connected to the car. The car is a symbol of absolute freedom from context, as it has no need for tracks (unlike the train), you can go wherever you please, with no need for a background to know that you are moving forward. With the car, the movement is intense enough in itself.

Stein's image of modernity is compelling because it is not the average traumatic one, where we see the relevance of tradition and anchoring dissolve, leaving the modern individual completely free floating and lost. Instead it is a self-contained position that is perfectly illustrated by technological progress in transportation. Yet, on the other hand, as is illustrated by the camouflage trucks of cubism, Stein is strikingly well in accordance with the close ties between inventions in media technology and warfare drawn by many media theorists, most prominently Friedrich Kittler. Here, it seems that, apart from being expressed by the innovative artists of a period, any new composition needs a war in order to be realized by the rest of the world. Stein makes this somewhat unpleasant aspect very explicit in Picasso:

It is an extraordinary thing but it is true, wars are only a means of publishing the things already accomplished, a change, a complete change, has come about, people no longer think as they were thinking, but no one knows it, no one recognizes it, no one knows it except the

9 Ibid., p. 287-288. 
creators. $(\ldots)$ the war is only something which forces everybody to recognize it. ${ }^{10}$

So, after the end of the war that had ostensibly publicized the composition already expressed in art and literature, Stein found that the time was finally ripe for publishing her own work. In 1920, she started intense preparations for getting out the first major collection of her writing. As usually in Stein's publication history, getting a book out proved somewhat difficult, but in 1922 Geography and Plays, containing an extensive selection of her work written between 1910 and 1920, was finally out. The book's title introduces into Stein's published vocabulary two new categories of writing within her system of genres, both of which are essentially spatial: the crucial notion of the play and the central concept of "Geography".

As has been well covered in the reception, Gertrude Stein's plays are readily recognizable as spatial due to their characteristic non-narrative and non-sequential construction. ${ }^{11}$ As Stein herself put it, "anything that was not a story could be a play" designating her own plays as "landscapes" rather than stories. ${ }^{12}$ Moreover, spatiality is a defining characteristic of the genre: all written plays are texts that have inherent in them a potential realization in the concrete, physical space of the stage. But in fact, it is the other half of the books' title, the - in a literary context - more enigmatic concept of "Geography" that connects most directly to Stein's experiences with driving through the open French landscape. In Stein's writing, geography is “never simply about location, scenery and the space of the earth, though it includes these" ${ }^{13}$ but is equally concerned with the spaces of writing, with spatiality as a principle for composition. Geography, in Stein's poetics is concerned with the arrangement of words

10 Gertrude Stein, Picasso. In Writings 1932-1946, New York: Library of America 1998, p. 518.

11 See for example Elinor Fuchs The Death of Character, 1996 and Bonnie Marranca "Presence of Mind" in Ecologies of Theater, 1996.

12 In her lecture "Plays" from Lectures in America. Quoted from: Writings 1932-1946, New York: Library of America 1998, p. 261.

13 Ulla E. Dydo and Gertrude Stein, A Stein Reader, Evanston: Northwestern University Press 1993, p. 467. 
in compositional space not tied to the stage, but to the written page.

Stein explored the concept in briefer compositions like "Geography"14 from 1923, where water, weather and waves become dominant free-floating elements in a punning flow of words that abandon sequence on a purely linguistic level, as well as in several other works written up through the 1920s. But it was not until years later, when she had traveled to America on her 1934 lecture tour and had her first experience with flying, that her concept of geography became fully unfolded.

Stein went back to America as she had left it, by steam ship, but well over the pond she became acquainted with the dawning aviation industry, as she was invited to attend the Chicago premiere in November 1934 of her success opera Four Saints in Three Acts ${ }^{15}$ only a few weeks after her ship had reached New York. Stein was absolutely terrified of heights and only very reluctantly led herself persuade to take the trip, on the condition that she could bring both Toklas and their friend Carl Van Vechten to hold her hand. As it turned out, she was absolutely thrilled by the experience.

After returning from America Stein wrote The Geographical History of America or The Relation of Human Nature to the Human Mind (1936), in which she developed her concept of "geography" to become a whole mode of writing that extended beyond her spatial sense of composing for the theatre and beyond the traditionally framed prose text of "Geography". In this peculiar and complex work of literary meditation Stein performs her most elaborate investigation and manipulation of the formalized, material components that organize written texts spatially as well as sequentially by sophisticating her

\footnotetext{
14 Like so many other compositions by Stein "Geography" remained unpublished in her lifetime, and was first printed in Painted Lace, and Other Pieces, the fifth volume of the Yale edition of the Unpublished Writings of Gertrude Stein in 1955. Reprinted in A Stein Reader in 1993.

15 The opera with music composed by Virgil Thomson had premiered in Hartford, Connecticut in February 1934 and then ran for over two months on Broadway, becoming the longest-running opera on Broadway ever at this time. Stein's libretto was first printed in extracts in transition 16/17 in 1929 and in its entirety in Operas and Plays in 1932.
} 
concept of "geography." It becomes a functional, broad, and spatially conceived perspective on composition that challenges the sequential progress of linear narrative. In her history of geography, Stein makes a new combination in writing of time and space that is derived from her experience of seeing America from above. The text promises to be a description of "how the country looked as we passed over it" and "of how the land the American land the land in America looks and is flat is and looks flat". ${ }^{16}$

These promised descriptions of the country are never realized in further detail in the highly playful, punning text, that appears compelling, crystal clear and easy to follow when one is reading it - and yet completely impossible to paraphrase whenever one stops reading. But a new freedom clearly comes into Stein's practice of geography in this work. Evidently, this happened in direct connection with her experience of air travel, because flying introduced to her a fundamentally different relation between time and space than the one she had known from driving. In a car, Stein suggests, you see the landscape changing swiftly as you go by, whereas when you are on a plane the landscape appears complete at every moment: what you see almost does not change from one moment to the next. This is something more radical than the plane's independency of designated roads and of the entire flat surface of the earth that it makes effortlessly perceivable for its passengers. In Stein's experience, what is so radical about flying is that her experience of progression in the journey is so small that it becomes almost non-existent. This fundamentally affects her mind as traveler and artist and in the course of The Geographical History it is continuously transferred from the space of the earth to the space of the writing and back again, as she writes in Chapter II: "This chapter is to be all about when words (...) look like that. Like that. Like it did when I looked at it, there there where I saw it. Beneath me when I was above it." ${ }_{17}$

16 Gertrude Stein, The Geographical History of America or The Relation of Human Nature to the Human Mind. In: Writings 1932-1946, New York: Library of America 1998, p.

373 and p. 383 .

17 Ibid., p. 380. 
The Geographical History of America proceeds through chains of literary genre miniatures, indicated by headlines such as "Autobiography number one", "Autobiography one again", "Detective Story number VII", "A little play", "Play number X", and constantly shifts and shuffles loose running structural units like "Chapter 2", "Part III", "Part fifteen", "Act I Scene I", "Number six and seven", "Example Four" and "Interlude I", explicitly defying the rules of sequence to create a simultaneous spatial murmur of elements co-existing on the space of the pages but refusing to organize themselves temporally. In another one of the countless occurrences of a "Chapter II" this principle is confessed: "There is no reason why chapters should succeed each other since nothing succeeds another, not now any more. In the old novels yes, but not now anymore (...) Everybody knows just how nothing succeeds anything." 18

Just like Stein's numbering of the different structural units seems to fall completely off the chart, there are also very few text-intrinsic indicators supporting the frequent changes in genre labels. The same style of punning prose progressing by its own mediational logic of chatty yet serious literary thinking runs through the whole work. Yet, the text insists strongly on the importance of the genres and units, and half through, not in a Chapter II but in a Part II, makes yet another chain of bold claims about genre that seems to immediately disarm each other:

The whole book now is going to be a detective story of how to write.

A play of the relation between the human nature and the human mind.

And a poem of how to begin again.

A description of how the earth looks as you look at it which is perhaps a play if it can be done in a day and is perhaps a detective story if it can be found out. ${ }^{19}$

18 Ibid., p. 390.

19 Ibid, 409 
Yet, clearly, all the generic labels are equally true, as Stein in the genre-miniatures of Geographical History of America Stein is demonstrating the functionality of genres as a spatial perspective that does not follow from the inherent characteristics of a text, but is something that is applied to a text, and when it is, changes that text radically. That "this whole book" is "a play if it can be done in a day" and "a detective story if it can be found out" suggests two completely different approaches to reading the same text. This spatial take on literary genre has a similar implication as a theatrical translation of a written play into a three-dimensional theatre space, even if it, in terms of medium, stays on the flat surface of the paper.

With flying, Stein's perspective on space and time was radically transformed: "One must not forget" she concludes in $P i$ casso "that the earth seen from an airplane is more splendid than the earth seen from an automobile". And continues:

The automobile is the end of progress on earth, it goes quicker but essentially the landscapes seen from an automobile are the same as the landscapes seen from a carriage, a train, a wagon, or in walking. But the earth seen from an airplane is something else. And so the twentieth century is not the same as the nineteenth century.

She goes on to identify in the American landscape she overflew on her first plane ride from New York to Chicago "all the lines of cubism made at a time when no painter had ever gone up in an airplane". ${ }^{20}$

Clearly, the experience of flying retrospectively influenced Stein's understanding of painterly cubism, but even more it influenced how she conceived and composed her own writing, as is demonstrated by the geographical concept of composition that she develops in The Geographical History and revisits in late key works like Ida. A novel (1941) and Four in America (1947).

20 Gertrude Stein, Picasso. In Writings 1932-1946, New York: Library of America 1998, p. 532-533. 


\section{Singing Satellites and Sounding Birds}

Jakob Lien

History changed on October 4th 1957 when the Soviet Union successfully launched Sputnik 1, the world's first artificial satellite, and sent the first man-made object in orbit around Earth. Only one month later the Russians launched a second satellite, this time with a living passenger onboard - the famous space dog Laika. When the satellite reentered into earth's atmosphere 162 days later, Laika had already been dead for a long time. The following year, the Russian cosmonaut Yuri Gagarin, became the first human to journey into outer space and NASA was founded. The accelerating space race between the Soviet Union and the US was a fact and became a crucial component of the cold war era.

While the launch of the first satellites became a decisive factor in the frightening arms race, it was also a source of deep fascination for people all over the globe. Ten years after the launch, the Canadian media theorist Marshall McLuhan pointed out that the new satellite technology came to forever change our view of ourselves: "Our psyches acquire thereby a totally new 
rim-spin". With the help of the satellite, seeing ourselves from a wholly new perspective became possible for the first time. While the new space technologies celebrated great triumphs and space became the new frontier, satellite images at the same time accentuated the insignificance of humans on earth from a geomedial perspective. With the satellite as a vector for our fantasies, a kind of cosmic vertigo, or an ontological doubt, emerged. The notion that the human was an unchallenged focal point was suddenly disturbed. Both nature and technology appeared at this point more hostile and more fragile than ever before.

In 1987 the term "overview effect" was coined by the American author Frank White to describe the cognitive shift in awareness reported by astronauts during spaceflight, while looking at earth from orbit. ${ }^{1}$ Many returning space travelers have claimed that when viewing earth from such a distance, they were overwhelmed and awed by the fragility and unity of life. One astronaut said that he "was hit in the gut with an undeniable, sobering contradiction." It is this shift in our cultural imagination as it is examined by two Swedish art works from the 1960 s, that I want to focus on in this article.

\section{Birds in Sweden}

In early winter 1963, the artist Öyvind Fahlström's eclectic radio composition Birds in Sweden was broadcasted by the Swedish National Radio for the first time. The listeners that were awake in front of their radios that winter night would soon experience something they had never heard before. The 30-minute composition starts with the sound of steps on a staircase and a door shutting. After that, a voice is heard reading an allusive quote from a book about parapsychology before the soundtrack from the sci-fi movie The Forbidden Planet from 1956 is slowly cued in in the background. The composition, or the "radio-phonic poem" as Fahlström called it, then continues as a collage of sounds and voices in a strange mix of poetry readings, animal sounds, field recordings, speeches, music and noises from diffe-

1 The concept was coined and explored in his book The Overview Effect - Space Exploration and Human Evolution (1987). 
rent technologies (like jet engines and guns, for instance). And then, there is something else, something intermediate that oscillates between animate sounds, spoken language and complete nonsense. What the listener is hearing pop up from time to time throughout the radio composition is a language invented by Fahlström himself, called "fåglo" or, in its English version, "birdo". The title of the work, Birds in Sweden, gives us a clue as to what kind of languages these are. It is a direct loan from the title of the classic field guide to birds by the ornithologist Erik Rosenberg that came out 1953. This was thee first Swedish handbook containing onomatopoetic transcriptions of bird songs, something that triggered Fahlström to begin working on the radio composition. As Jesper Olsson has noted in an essay on Fahlström's sound art noted: "birds and their communication system were the catalyst for his work [Birds in Sweden]."

Why would Fahlströhm make up invented bird languages, one might ask? If we look at Fahlström's earlier aesthetic practices we find a continuity in his interest for communication systems and questions about the limits of language. 1953, 10 years before Birds in Sweden, Fahlström wrote the influential manifesto for concrete poetry where he describes the idea about "kneading language as concrete material". ${ }^{2}$ This endeavor to explore and systemize language, in order to be able to play with and manipulate it, is manifest also in his work with the invented languages birdo and fagglo - even though he now extends his antennas outside the purely human communicating system. Two early sketches from 1962 shows how Fahlström worked out these "artificial" languages as an act of translation where the syllables of a given word were mimicked with onomatopoetic counterparts. Birdo and fagglo are in fact translations from sound imitation to sound imitation through written language. The languages were not meant to be fully thought-out systems possessing inner logic and grammar, but are rather created as acts of "kneading" and exploring the limits of different sign, sound and communication systems. Or as Fahlström said in a radio interview in 1963: "I think the actual translation process is highly significant, as what

2 Öyvind Fahlström, "Hätila ragulpr på fåtskliaben”, Odyssé nr. 3-4, 1954. 
we are engaged in our [sic!] attempts at perceiving the world, in the way we perceive reality, is translation in accordance with various systems; all systems are of equal worth. [...] Language, too, is a meaningless system that is great fun to play with." ${ }_{3}$

If birds and their communication systems are the most obvious catalyst for Fahlström's work, there is another, maybe more elusive, but equally important catalyst for the radio composition as a whole - namely wireless communication systems. Radio is of course the most apparent technology at play here, but at the end of Birds in Sweden another technology is introduced. Over a cacophonic sound of birds, the music of the 1962 number one billboard hit by the surf group The Tornados slowly fade-in as a second layer in the soundscape. (fig. 5) The track is titled "Telstar", after the first private communication satellite launched less than one year before Birds in Sweden was broadcasted for the first time.

In an educational documentary about the Telstar satellite from the same year it was launched, we initially hear an alarming sound from a receiver turning its antenna up into the sky, poised to follow Telstar's orbit in space. After that, a film sequence of space is shown while dramatic music is played in the background, shortly thereafter the setting changes again. We are now back on earth and a calm voice can be heard, telling us about a "tiny spinning globe that will rise from the Florida beach." Whether or not Fahlström himself, who lived long periods of his life in America, saw this particular documentary, is impossible to determine, but it's not hard to envision what kind of fantasies such an event would spark in anyone's imagination. The success of The Tornados' odd sci-fi inspired surf song could hardly have been imaginable without a general excitement about this new technology. And considering Fahlström's interest in language as well as in communication and technology, it is almost a logic consequence that he found and incorporated the launch of the first private communication satellite as a crucial component of Birds in Sweden.

\footnotetext{
3 Fahlström talks about his work on Swedish National Radio in 1963. Teddy Hultberg, Öyvind Fahlström on the air - Manipulating the World: Birds in Sweden, The Holy Torsten Nilsson, Pictures \& Manuscripts, Sveriges Radio, Stockholm, 1999, p. 93.
} 
In many ways, the new communication satellite embodies the "perfect arc", to paraphrase McLuhan, between the animate sounds of birdsongs and the inanimate sounds of technologies. In cultural representations, birds have for a long time played the role of messengers, the connections between distant places - much like the satellite does today. A very concrete example is of course the carrier pigeon, but even in nature, birds function as agents of seed dissemination. The American art historian Sergio Bessa has noted that: "there are hints in Birds in Sweden of birds becoming machines, of machines as extensions of natural organisms, and ultimately of nature being superseded by technology." 4 I agree with Bessa to some extent, but would not go quite as far. Instead, I would suggest that there is a constant reciprocation between birds and technology, opening up for the possibility of satellites becoming birds as well.

The final lines in Birds in Sweden (that are interpretable for us humans) go: "kiss the earth, kiss the earth" and then "don't kiss the earth, don't kiss the earth". Isolated these words may "seem to apply a call to a return to nature", as Bessa suggests. ${ }^{5}$ But if we consider the larger context where these words can be heard, enmeshed in the sounds of jet engines, satellites, birdsong etc., the lines seem to suggest a transgression of traditional boundaries between nature, human, and technology. Creating a new ecology, highlighting a communication situation where human language is no longer the dominant form.

\section{Altisonans}

My second example exploring the shift in our cultural imagination in regard to technology and nature, is a film called Altisonans from 1966 by the Swedish artist and composer KarlBirger Blomdahl. The work was broadcasted as a part of an experimental film program on the national Swedish television, and it has a lot in common with Fahlström's work Birds in Sweden; both being broadcasted with wireless technologies but

\footnotetext{
4 Antonio Sergio Bessa, Övind Fahlström: The Art of Writing, Northwestern Univesity Press, Evanston, Ill., p. 127.

5 Ibid., p. 130.
} 
more importantly, both using birds and satellites as their main incentives to explore different communication systems. At the time Altisonans was finished, Blomdahl was a well-known composer and public figure in Sweden. Blomdahl became famous, not least, for introducing electronic music in an opera for the first time in Sweden, when his opera Aniara premiered in Stockholm in 1959. The opera is based on the Swedish Nobel prize winner Harry Martinson's sci-fi inspired 1956 poem of the same name. It became a huge success and is still today the most seen opera in Sweden. Blomdahl's interest in techno$\log y$ and nature goes back to the 1950 s when he started to do field recordings of earth sounds, which he then transposed into electronic music. Parts of these compositions were later used in Aniara. But it was when he met the Polish geo-cosmo-physician Ludwik Liszak for the first time, at a solar observatory at Capri, that the idea for Altisonans started to grow. When Liszak let Blomdahl listen to sounds from space, he realized that there were a lot of sonar similarities to birdsong - and more specifically to the mating call by the Naumann's Trush (or Rödtrast). He started to collaborate with Liszka and went to the geophysical observatory in Kiruna, located above the arctic circle, to do recordings of electromagnetic signals from satellites and astrophysical objects. The result can be described as an audio-visual collage of birdsongs that gradually coalesce with the sound of the man-made satellites in space. The work stages two parallel soundscapes - one "natural-sounding" world inhabited by birds on the face of the earth, and one artificial some hundred kilometers out in space - merge into a new kind of communication system. In communication theory voices and sounds usually are used to locate subjects and objects in the world, and by doing so, they are in a way restricted from the opportunity to explore and form new configurations. But in Blomdahl's work the sounds from the subjects and objects are instead used to breach borders between different entities and intertwine the parts they play in the ambient ecology formed by the new satellite technology.

So far, I have been focusing on these two works as historical 
examples of how the new satellite technology inspired artistic examinations and reconfigurations of aesthetic practices during the 1960 s. But I also think that both Birds in Sweden and Altisonans have a critical relevance today, not least in relation to the ongoing discussion about what has been called "the non-human turn" in humanities. Both works actualize the question of how we could tackle today's geo-political and social challenges as well as climate change, suggesting alternative ways of distributing our relations, not only to each other but also to the nonhuman beings around us.

Of course, talking about a non-human turn when satellites in fact are man-made technologies may seem murky, but rather than addressing these technologies as "extraordinary achievements by mankind" both Fahlström's and Blomdahl's works seem to focus on what happens after or beside human intervention. Erin Manning, an American artist and philosopher, have suggested that art always has a participatory quality that works "without human intervention, activating fields of relation that are environmental or ecological in scales of intermixings that may include the human but don't depend on it." For me, it is exactly these kinds of relations that Birds in Sweden and Altisonans activate by exploring what happens if we exceed the regulated protocols of communication that we until now have built our conception of the world upon. They do not only lead us to think about the communication of technologies among themselves or between one animal and another, but also between the inanimate and the animate. Or, to rephrase, both works explore what happens when birds start to sound and satellites to sing.

6 Erin Manning, "Artfulness", in The Nonhuman Turn, Grusin, Richard (ed.), University of Minnesota Press, Minneapolis, London, p. 72. 


\section{Literature:}

Bessa, Antonio Sergio, Öyvind Fahlström: The Art of Writing, Northwestern University Press, Evanston, III., 2008

Fahlström, Öyvind, "Hätila ragulpr på fåtskliaben”, Odyssé nr. 3-4, 1954 Manning, Erin, "Artfulness", in The Nonhuman Turn, Grusin, Richard (ed.), University of Minnesota Press, Minneapolis, London, 2015

Olsson, Jesper, "Radiophonic Poetry and a Blind Movie - Öyvind Fahlström's Sound Art", in A cultural history of the Avant-Garde in the Nordic Countries 1950-1975, Ørum, Tania \& Olsson, Jesper (ed.), Brill/Rodopi, Leiden, 2016

Hultberg, Teddy, Öyvind Fahlström on the air - Manipulating the World: Birds in Sweden, The Holy Torsten Nilsson, Pictures \& Manuscripts, Sveriges Radio, Stockholm, 1999 


\section{Det perikapitalistiska landskapet}

\section{Jenny Jarlsdotter Wikström}

The Mushroom at the End of the World: On the Possibility of Life in Capitalist Ruins

Anna Lowenhaupt Tsing

Princeton University Press, 2015

I boken The Mushroom at the End of the World granskar antropologen Anna Lowenhaupt Tsing kapitalismens gränsland. Som sin särskilda kompanjon i detta utforskande utser hon svampen goliatmusseronen, även kallad matsutake. Tsings anspråk är, för att uttrycka det milt, mycket stora: hon vill bygga en verktygsback för en feministisk anti-antropocentrisk kritik av kapitalismen. De ambitiösa anspråken vägs upp genom att Tsing genomgående betonar vikten av det partikulära. Hur kapitalismen fungerar som en praxis där säljare och kund förs samman, hur oväntade handelns vägar kan te sig i ett landskap där svampar, tallar, flyktingar och samhällets utstötta möts. Hon väljer en negligerad handelskedja - handeln med goliatmusseronen - som sitt exempel eftersom hon ser att det där, i det prekära, sårbara och oväntade, öppnar sig en möjlighet för en analys av kapitalismen som ett öppet system som det är möjligt att förändra. Mushroom är följaktligen ett slags manifest för en annan typ av kapitalismkritik än vad vi är vana vid.

Efter uppsvinget för kritiska djurstudier under 2000-talets 
första årtionde har växter hamnat i fokus. Bland annat Jeffrey T. Nealon för fram i Plant Theory. Biopower \& Vegetable Life (Stanford University Press, 2016) att växtligt liv svårligen ryms inom den kritiska teorins ramverk. Svampar, å sin sida, har fått en liknande uppmärksamhet den senaste tiden, inte minst genom Tsing och hennes kollegers forskning om goliatmusseronen, som växer i Japan, Kina, USA, Kanada och vissa delar av Skandinavien.

Varför just goliatmusseronen, kan en fråga sig. En förklaring är att den är otroligt efterfrågad men inte kan odlas i laboratorium. Svampen är en av världens dyraste och måste plockas $\mathrm{i}$ skogen. Det betyder att goliatmusseronen ingår i en komplex kedja av svampplockare, köpare och internationella förmedlingsagenturer, och, förstås, även som en del av själva skogen. Tsing ser här det hon kallar ett "perikapitalistiskt" landskap: i utkanten av handelskedjan finns plockare, som för både nöjes och pengars skull letar efter spåren av den värdefulla svampen i skogar världen över.

"Follow fungi to that underground city, and you will find the strange and varied pleasures of interspecies life" (138), skriver Tsing. Den underjordiska stad som hon i sällskap med plockare finner under den täta mattan av tallbarr kopplar samman kroppar och livsvärldar märkta av den globala kapitalismen. Goliatmusseronerna lever intimt sammanlänkade med sina värdträd - i detta fall olika typer av tall - för att få tillgång till näring $\mathrm{i}$ marken genom svampens rottrådar; svampar jobbar rhizomatiskt, de äter sten och jord och döda växtdelar och formar aktivt sin levnadsmiljö. De är del av ett intrikat, levande nätverk som är sårbart för förändringar. Tsings poäng är att alla arter uppkommer och lever på detta sårbara, känsliga rhizomatiska sätt, men i goliatmusseronens fall framgår det med extra stor tydlighet.

De nätverk som Tsing spårar är varken harmoniska, idylliska eller ofarliga, vilket också är en av bokens allra viktigaste poänger. Goliatmusseronen trivs i förstörda landskap, där lantbruk och skogsbruk har orsakat kalhyggen och ödelagt biotoper. Svampen trivs till och med där det inte finns någon växtjord att 
tala om. Därför är svamp en bra ledstjärna till teoretiseringen av återväxt, motsträvighet, och naturens agens och påhittighet. De utmanar antropocentriska föreställningar om individualitet, agens och intentionalitet genom hur de skapar livsvärldar tillsammans med andra arter också i landskap där skogsmaskiner tuggat sönder träd och jord. Svampar är, enligt Tsing, utmärkta guider till att förstå kapitalismen just av den anledningen - de lever kvar i ruinerna, när kapitalismens skogstuggande maskineri har dragit vidare.

Kapitalismen är ett system, framhåller Tsing, men inte ett slutet sådant. Dess logik äter upp skogar, men upphör efter att skogsmaskinerna avverkat den värdefulla skogen och lämnat kvar ett öde land utan värde. I det öde, prekära och vid första anblicken förstörda landskapet frodas sedan goliatmusseronen. Handeln med goliatmusseronen är beroende av skogslandskapet och av människor som letar och plockar svamp, men även av andra informella handelslogiker som inte följer kapitalismens rätlinjiga lagar om produktion, utbud och efterfrågan. På så sätt hittar Tsing en öppning till en kritik av kapitalismen i hur goliatmusseronen inte kan anpassas till kapitalismens logik utan förblir sin egen. Svampen finns - eller så finns den inte. Och någon måste också hitta svamparna för att de ska kunna bli en vara på den globala marknaden.

Svampen ingår därför inte bara i nätverk tillsammans med växter och träd. De som plockar goliatmusseronen och som Tsing följt under år av fältarbete är också på flera sätt präglade av kapitalismens framfart. I Oregon är svampplockarna ofta av sydostasiatiskt ursprung. I boken skildrar Tsing hur hon intervjuar och plockar svamp tillsammans med medlemmar ur mien-, lao- och hmongminoriteter, människor som tvingats fly från krig eller som valt att emigrera. Med sig har de haft kunskapen om var och hur svampen lever. En annan del av svampplockarna i Oregon är amerikanska krigsveteraner som velat lämna en i deras ögon svekfull civilisation. Plockarna som Tsing intervjuar är överlevare, de har överlevt krig, de har också ofta själva begått våldsbrott, och förenas av en odefinierbar längtan efter "frihet". Plockarna väcker själva frågor om vad det vill säga att överleva 
i en skrämmande, föränderlig och förstörd värld. Här finns en koppling till den tes som Timothy Morton driver i boken Hyperobjects (2013): vi kan inte "rädda världen", den värld vi vill rädda har redan gått under för länge sedan. Frågan är vad som sker efter världens undergång, vem eller vilka är det som finns kvar när dammet lägger sig. Vad är förstörelse, och för vem?

Det anmärkningsvärda med Tsings bok är hur hon ser ickemänskliga livsvärldar som helt grundläggande för kapitalismen, och hur hon formulerar möjligheter till förändring av kapitalismens struktur. Hon letar aktivt efter platser och landskap där den kritiska teorin brister, där den marxistiska feminismens analyser av arbete, varulogik och produktionsförhållanden helt enkelt inte håller måttet eftersom den inte tar icke-mänsklig agens i beaktande. Mushroom kan också läsas som en fortsättning på den kritik av antropocenens narrativ som feminister, svarta feminister, queer- och transforskare formulerat. De komplexa och heterogena nätverken som goliatmusseronen skapar och är en del av löper djupa och vildvuxna genom kroppar; träd, skogar, svampplockare, försäljare, lokala handelsplatser, fram till någons tallrik och in i kroppar som hakar i andra kroppar. I likhet med J.K. Gibson-Graham i A Postcapitalist Politics (University of Minnesota Press, 2006) vill Tsing utveckla nya kritiska redskap, och startar med att medge att kapitalismen inte är en monolit, utan ett system med gränser. Vad kan vi göra av denna vetskap om att kapitalismen är beroende av ickekapitalistiska praktiker, frågar hon sig. "Economic diversity enables capitalism but also undermines its hegemony" (132), förklarar hon.

Fokuset på det materiella är ett effektivt sätt att kringgå alienationsproblematiken, det vill säga separationen mellan den sammansatta produktionen av en vara och varan själv. Svampen skapas inte ur intet, den är en relation mellan mikrober, alger, jordmån, träd, en hel livsvärld som sedan vecklas in i människorna som plockar den, vilka i sin tur snärjs in i kapitalismens mångfacetterade nätverk. Kedjan har varken en tydlig början eller ett tydligt slut och blir således ett exempel som stöder Tsings hypotes om att kapitalismen så att säga läcker. Genom att metodiskt arbeta med en relationell etik i analysen av goli- 
atmusseronens varufiering kan Tsing visa på hur motsägelsefull kapitalismen är, hur den bygger på komplexa relationer som är svåra att greppa med den befintliga marxistiska teorins redskap. Boken fungerar således som en typ av handbok, eller ett slags manual, och bör således slutgiltigt värderas enligt hur den sätts i omlopp och används av andra forskare, inom andra discipliner under åren som kommer.

Tsings slutsatser har också problematiska sidor. Å ena sidan strävar hon efter att återge och analysera kapitalismen som ett öppet, läckande och föränderligt system. Å andra sidan platsar goliatmusseronen så väl in i analysen att läsaren blir misstänksam: är allt frid och fröjd nu när vi förstått att kapitalismen har inbyggda brister? Hur ska vi motarbeta miljöförstörelse, ekonomisk ojämlikhet och rovdrift, om dessa bara är tecken på kapitalismens förestående undergång? Ska vi bara vänta och se? Visst är det viktigt att teoretisera förstörelse och naturens egen förmåga att förgöra och skapa nytt, men det som går förlorat när kapitalismen upphör att vara ett system är ju just systemkritiken, protesten, motståndet. Kan inte också diskursen om den monolitiska kapitalismen ibland förstås som "strategisk essentialism" som gör den hanterbar, möjlig att motarbeta? Kan inte hederlig, gammal systemkritik användas till någonting alls? Goliatmusseronens förmåga att frodas på ställen där marknaden dragit vidare kan ju lika väl förstås som helt i enlighet med kapitalismens marknadslogik: där ingen marknad finns, skapas en ny.

Jag fick smaka goliatmusseron tack vare en kollega vid Umeå Universitet, som känner någon, som i sin tur känner någon som hittat svampen i Vindeln, en liten stad nordväst om Umeå. Den smakade umami, en sträv men varm smak. Genom den kedjan av händelser ingår också jag nu i nätverket som Tsing spårar, det löper genom svampen på tallriken in i min kropp, och vidare. Just den här goliatmusseronen var en gåva till min kollega, som i sin tur delade gåvan med mig. Det här kan tänkas vara oviktiga 
detaljer, men så är det inte. Och här håller jag med Tsing, varan, i detta fallet svampen jag äter, är inte bara en funktion, den är materia, den har en egen tyngd och den lämnar spår som inte platsar inom den traditionella marxistiska varulogiken. Materialiteten finns oberoende av kapitalismen, svampen är sin egen.

De märkliga, invecklade turer som varor och varelser gör inom kapitalismen visar på brister och håligheter i systemet. Kanske visar de även på möjligheter till förändring, om vi ska tro Tsing. På många sätt är nyfikenhet nyckeln till den förändringen, för hon fram: "Not that it will save us - but it might open our imaginations." (19). Frågan är vart en mer öppen föreställningsförmåga leder. 


\title{
Molnet på jorden
}

\section{Johan Fredrikzon}

\author{
Tung-Hui Hu \\ A Prehistory of the Cloud \\ MIT Press, 2015
}

Det berömda "molnet" är sedan åtminstone ett halvt decennium synonymt med hur vi lagrar och hämtar digitala data. Med sin nebulösa struktur och ständiga men omärkliga närvaro är datamolnet en närmast övertydlig symbol för digital kommunikation som någonting immateriellt, abstrakt och metafysiskt. Tung-Hui Hus bok A Prehistory of the Cloud är den senaste i raden av mediehistoriska undersökningar som försöker att nyansera och korrigera den dominerande uppfattningen av molnet genom att förankra dess nutida utformning i konkreta historiska situationer samt visa på konsekvenserna av det som författaren benämner kulturella fantasier omkring våra fluffiga informationsströmmar. Tack vare bokens flyhänta framställning av originellt empiriskt material ( $\mathrm{Hu}$ är även verksam som poet) knyter den an till så olika publikationer som Bruce Schneiers populärt hållna Data and Goliath (2015) å ena sidan och John Durham Peters lärda medieexkursioner i The Marvelous Clouds (2015) å andra sidan.

$\mathrm{Hu}$ är föredömligt pedagogisk när han leder läsaren i in un- 
dersökningen. Så här sammanfattar han bokens underliggande fråga $\mathrm{i}$ inledningskapitlet: Om molnet är en kulturell fantasi (kapitel 1) av deltagande (kapitel 2) och säkerhet (kapitel 3), vad händer då när användare deltar i sin egen säkerhet? (kapitel 4)? För att besvara frågan går han i tur och ordning igenom molnets nätverk, virtualisering, lagring och gränssnitt. Den som är datatekniskt skolad känner igen upplägget: framgångsättet tillsvarvar OSI-modellen för att beskriva abstraktionslager inom datorarkitektur och -kommunikation. Hu har två huvudsakliga ärenden med sin studie. Dels vill han visa hur de trådlösa nätverk som omger oss vilar på infrastruktur betydligt äldre än datateknik, dels att molnet som begrepp går långt utöver specifika teknologier för att bli verksamt som metafor för vår tids förståelse av informationsteknologi. Så visar författaren hur de tillsynes virtuella tjänsterna alltid kan knytas till fysiska kablar och konkreta datacenter som förbrukar enorma mängder energi och vars ägare köper billig arbetskraft i låglöneländer, samt att dessa rutter inte sällan löper längs gamla järnvägar och avloppstunnlar eller är lokaliserade i forna militärkomplex och bunkrar från kalla kriget. Kunskapen är inte ny, invänder någon, men nog kan den behöva upprepas och då gärna av en inspirerad följeslagare som Tung-Hui Hu. Det intressanta med A Prehistory of the Cloud är kombinationen av ett brett kulturhistoriskt anslag med rika associationer till de senaste decenniernas politiska utveckling och en gedigen förståelse för datorsystemens teknologiska ramverk. $\mathrm{Hu}$, litteraturvetare och poet med en bakgrund som nätverkstekniker, tar med läsaren in mellan de surrande fläktarna i de enorma serverhallarna för att så att säga tvinga materialiteten ur molnet. Greppet påminner snarast om när Sven Lindqvist i Hemmaresan (1959) följde rören på dass hela vägen till reningsverket och krävde att få veta varifrån vattnet kom och hur systemet såg ut bakom kaklet, under vägen, på andra sidan skogen. Hu liknar dataflödet vid just vattnet i kranen, denna samtidigt komplexa och banala tjänst som blir osynlig $\mathrm{i}$ samma stund vi lär oss att ta den för given. Det går att se Hus arbete som del av en mediearkeologisk utgrävning av de trådar - synliga och ej - som löper kors och tvärs över världen, en vilja 
att veta riktad mot infrastrukturen och dess svarta lådor, en digital "gräv-där-du-står"-rörelse med kritiska och demokratiska undertoner som vi förmodligen bara sett början på.

Det övergripande syftet med framställningen är att kritisera de slentrianmässiga attityderna till de globala datanätverken molnen - som oproblematiska gratisverktyg för effektiv kommunikation, ett slags outtömliga reserver för beräkningskraft och lagringsutrymme, lätta som luft och med demokratisk och frigörande potential. Här riktas kritik mot såväl etablerad medieforskning som politiska diskurser, branschmyter och populärvetenskapliga förenklingar. I argumentationen för sin sak aktiverar författaren ett mångskiftande källmaterial. Med några kvicka nedslag kan han visa hur nästan all internettrafik i USA löper längs rutter som etablerades på 1800-talet, att de i själva verket är starkt centraliserade och styrs av sex privata telekombolag. Att vi ändå talar om nätets distribuerade, fria och öppna karaktär menar $\mathrm{Hu}$ pekar mot att nätverket i första hand är en idé, en seglivad uppfattning om att "allt är sammankopplat", en utbredd åkomma som han med stadsarkitekten Doxiadis från 1970-talets Detroit betecknar "nätverksfeber": begäret att koppla ihop alla nätverk, varje liten informationsdel med alla andra. Ett slags motsvarighet, tänker man sig, till insamlingsiver, dokumentationshysteri, bevarandepanik och liknande institutionspatologier som tyngt arkiven och vetenskaperna sedan länge.

Bakom drivkraften att koppla ihop allt, skriver $\mathrm{Hu}$, finns en känsla av hot, en tärande osäkerhet om en obevakad läcka, en föraning om en nod som ännu inte är hopflätad med resten; en mörk fläck på kartan. Här uppstår, enligt författaren, det paranoida subjekt som ständigt eftersträvar att förmå omvärlden att ta form i enlighet med en inre kognitiv ritning med vars hjälp allting ska bli synligt. Problemet med paranoia som drivkraft är inte bara att den bygger på mer eller mindre ogrundade fantasier om fara. Genom att agera utifrån den upplevda hotbilden, bekräftar den indirekt dess existens vilket i förlängningen motiverar andra åtgärder, till exempel att ytterligare förskansa sig - eller åtminstone sina data - i skyddsrum eller öka graden 
av övervakning. Det tillgängliga och öppna datamolnet modellerat på förföljelsemani, således. Gamla frågeställningar kring datasäkerhetens psykologi tangeras med förtöjningar bakåt till krigets strategi och underrättelseverksamhetens historia.

Om besattheten att koppla ihop världens alla data i en komplett helhet bär paranoida drag, menar $\mathrm{Hu}$ att datacentrets arkitektur hellre är melankolisk till sin natur. Till varje pris vill det skydda och bevara uppgifter från yttre krafter. Liksom skyddsrummen från mitten av förra seklet, avsedda att stå emot bombräder och kärnvapen, förkroppsligar datacentret ett ständigt avvaktande inför katastrofen. Denna ordning - luftburna nätverk som är inlåsta i berget - gör att molnet på samma gång härbärgerar motsatta temporaliteter: realtid och väntan. Datahallen djupt inne i berget blir både vakttorn och likkista. Författaren gör flera träffande observationer när han rör sig $\mathrm{i}$ bunkermentaliteternas topografier, från Iron Mountain utanför New York till Pionen på Söder i Stockholm, där 1900-talets betongdörrar stänger inne 2000-talets digitala routrar. Genom det detaljerade historiska exemplet, genom att följa infrastrukturen i tid och rum, lyckas Hu visa att ingenting är fullt så nytt, fritt eller säkert som vi gärna vill tro. Framförallt lyckas han demonstrera hur nätaktivister och regeringar ofta drivs av samma upplevelse av hot, av idén att nätet är ofritt eller riskerar att bli det: "Internet måste försvaras", skriver han, med en bli blinkning till Michel Foucaults föreläsningar vid mitten av 1970-talet om krigets och rasismens problem. Lagringstjänster i molnet, "cloud storage", blir då ett sätt att skydda sina data från den Andre. Det som ur en vinkel ser ut som en global rörelse för nedrivna gränser och fritt tankeutbyte kan ur en annan beskrivas som fortsättningen på 1800-talets imperialism. Här gör $\mathrm{Hu}$ en viktig insats genom att problematisera säkerhetstänkandets förmåga att normaliseras till den grad att vi inte längre ser hur dess mekanismer från början är uppbyggda kring uteslutandets och utestängandets principer.

Till och med de läsare som redan är bekanta med den sortens analyser, bjuds på en rad intressanta fallstudier, till exempel om hur kollektivet Ant Farm i början av 1970-talet körde runt i en 
ombyggd skåpbil med vars hjälp folk gavs tillgång till datorer och videotjänster vid vägkanten i ett "truckstop network" för "media nomads" på utvalda platser i USA. Här skapades en vision av mobil data med hjälp av bilen och televisionen, en vision som skulle tas vidare när Stanford Research Institute 1976 för första gången upprättade kommunikation mellan två olika typer av datornätverk - "molnen" ARPA NET och PR NET - och där den ena noden utgjordes av just en skåpbil som parkerats utanför Rossotti's biker bar i Palo Alto för att pröva utrustningen i en "ogästvänlig miljö" så att militären kunde övertygas om dess lämplighet. Den sortens oväntade utflykter i nätets historia tillhör den verkliga behållningen med boken. Molnet är här varken det demokratiska universalverktyg eller det krigsfödda övervakningsinstrument det ofta framställs som - det är både och, samtidigt, och mer ändå.

En av de mest givande delarna av boken är kapitlet om "timesharing", alltså resursdelning vid datoranvändning på 1960- och 1970-talen. Det vill säga tiden innan datorn blev "personlig", en tid då varje beräkning var dyrbar och forskare, statistiker och andra fick stå i kö för att få tillgång till datorns förmågor. Timesharing var en metod för att lösa problemen med väntetid genom att låta datorn blixtsnabbt växla mellan olika förfrågningar så att var och en upplevde det som att hela dess beräkningskraft stod till ens exklusiva förfogande, trots att varje sekund av processorns arbete i själva verket fördelades på flera uppgifter. Ur time-sharing-modellen härleds även praktiker som att skilja på och namnge användare, att hålla koll på vad var och en sysslar med, hur resurser förbrukas m.m. Hu visar hur timesharing inte bara innebar "användarens" [the user] födelse utan även speglade en ekonomisk omställning i samhället från strikt lönearbete till olika former av flexibelt arbete utifrån personliga preferenser. Den här utvecklingen drar författaren hela vägen till nutida motsvarigheter som att oavlönat recensera produkter och rekommendera tjänster i onlineforum. Kritiken mot vårt omfattande gratisarbete får här en alternativ bakgrund som man inte behöver köpa fullt ut för att finna tänkvärd.

Författaren ser här början på värderingen av realtid som en 
ekonomisk storhet men även de första sammanblandningarna av begreppet "free" $i$ betydelsen gratis respektive fri, samt alla politiska och kapitalistiska implikationer det kan få när vi blandar ihop personlig och ekonomisk intimitet. Diskussionen är värdefull eftersom den öppnar för en kritik som hittills varit anmärkningsvärt svag gentemot nätets ekonomiska strukturer, nämligen konsekvenserna av ytligt sett kostnadsfria tjänster och varor som i slutändan konsumerar, så att säga, användarens eller medlemmens kanske viktigaste resurs - hennes tid - och därmed ytterst hennes frihet att tänka och handla självständigt. Nog kan det gå lite väl fort ibland när $\mathrm{Hu}$ associerar mellan olika perspektiv och fenomen - till exempel blir vissa psykoanalytiska läsningar av molnets egenskaper något långsökta - men oftast görs det med en smittande energi och retorisk elegans som måste bejakas. Emellertid ger undersökningens upplägg och anspråk anledning att fundera över hur vi skriver mediehistoria. De centrala värdena av A Prehistory of the Cloud är tveklöst författarens förmåga att öppna upp en ganska trång och ytligt kanoniserad berättelse om nätets födelse och hur de tidiga visionerna lett fram till vårt digitala samhälle med alla dess fördelar. Men samtidigt är $\mathrm{Hu}$ aldrig sen att själv slå fast hur nutidens "moln" har direkt samhörighet med stordatorernas kontofördelning för ett halvt sekel sedan eller hur det går en rak linje från kalla krigets bunkrar fram till dagens satellitstyrda drönarattacker. Han verkar således $\mathrm{i}$ en tradition där värdet av historieskrivningen till stor del grundar sig på huruvida fynden tydligt kan länkas till aktuella fenomen. Det gör framställningen potent men bitvis en smula vidlyftig, någon gång ansträngd.

Det som överlag fungerar sämst är författarens försök att föra in "suveränen" igen i den maktkritiska diskursen som först Foucault (delvis) övergav till förmån för en disciplinär stat, och som sedan Gilles Delezue och andra försökte ersätta med idén om kontrollsamhället. Till Hus försvar kan sägas att han (liksom Foucault) inte är beredd att förklara någon form av maktutövning obsolet, men det han kallar för "the sovereignty of data" förblir till slut något oklart. Till undersökningens största förtjänster hör istället att den först ställer upp ett antal narrativ 
som justerar utbredda troper och ytliga iterationer av myter för att sedan presentera små motbilder till sin egen historieskrivning. Detta genererar en läsart som inte tillåts vila mot enkla förklaringsmodeller. $\mathrm{Hu}$ funderar även kring det faktum att bankkonton, pornografi, militära dokument och e-post hålls noga åtskilt mellan användare men ändå ligger intill vartannat rent fysiskt i samma server någonstans i molnet. Kanske finns det rum för möten mellan individer när infrastrukturen rasar samman, ungefär som under en brandövning i en skyskrapa då människor som aldrig tidigare sett varandra trots att de arbetar i samma byggnad kommer i samspråk.

Författaren lyckas även fördjupa diskussionen om digitala motståndsrörelser genom att visa hur de i sista hand uppträder enligt de strukturer som en nyliberal ideologi förutsätter: de är aktiva deltagare, engagerade användare inom systemet, de delar data med hjälp av samma verktyg som marknaden eller staten. När vi taggar varandras bilder på Facebook för att bygga relationer kring en politisk demonstration utför vi ett slags obetalt arbete som i längden syftar till att bygga upp världens största databas för ansiktsidentifiering. Även mer avantgardistiska, subversiva och maktkritiska initiativ verkar inom en övergripande ideologi inte minst som de tvingas anpassa sig till standarder och protokoll av olika slag. "A hacktivist project", skriver $\mathrm{Hu}$, "to undermine the government looks like a security project meant to bolster the government". Denna gräsrotsbevakning eller "sousveillance" är problematisk även därför att den reproducerar en tvivlets blick som gränsar till det paranoida och riskerar därmed att motverka sitt syfte i längden. Resonemanget påminner om Bruno Latours självkritiska betraktelse om en intellektuell tradition som ifrågasätter till den grad att den riskerar att spela i händerna på konspirationsteoretiker.

Med stöd av bland andra Paul Virilio och Giorgio Agamben associerar författaren friskt kring hur kriget numera varken är ett undantag eller något som enbart stater eller terrororganisationer ägnar sig åt. Tvärtom visar $\mathrm{Hu}$ hur vanliga medborgare - användare - aktivt deltar i jakten på hotfulla eller främmande element tack vare molnets förmåga att samla avancerade verk- 
tyg för att söka i stora dataset, jämföra mönster, spåra via kartor och så vidare. En radiohackare i Holland som snappar upp och bloggar om det amerikanska stridsflygets positioner riskerar att underlätta för motståndarsidan under NATO-attackerna mot Libyen 2011. Med en hobbyutrustning för 500 dollar kan han påverka säkerheten för ett flygplan värt en halv miljard. En 48årig mellanchef på glassbaren Dairy Queen i Tuscon, Arizona bläddrar på sin fritid igenom satellitfotografier för att via Twitter tipsa NATO om Khaddafis kommunikationshögkvarter. Några timmar senare meddelar han stolt att försvarsalliansen bombat exakt de platser han pekat ut. Här är det återigen det närgångna empiriska materialet som får studien att lyfta. Att det verkar finnas ett slags långsamt våld (Rob Nixons begrepp) som utövas inom datamolnens domäner - inte sällan i klassisk nyliberal eller imperialistisk stil - är man nog beredd att hålla med om efter att ha tagit del av A Prehistory of the Cloud. Men om författaren sätter fingret på många paradoxer och inkonsekvenser eller rena felslut beträffande den digitala världens möjligheter till effektiv kritik och motstånd, förblir han ganska luddig beträffande vilka andra vägar som borde prövas. 


\title{
Gyroskopiske konsekvenser
}

\section{Ragnild Lome}

\author{
Mark Seltzer \\ The Official World \\ Duke University Press, 2016
}

Coverbildet til litteraturhistorikeren Mark Seltzers nyeste bok, The Official World (2016), er hentet fra performanceverket $A b$ solute Helligkeit av kunstneren Naoko Tanaka. Tanakas performanceverk består av et rom med en bevegelig lyskilde, som lyser opp nye verdener fra forskjellige steder - bak et skrivebord eller under en stol kommer forunderlige tablåer til syne. Tittelen på verket, direkte oversatt «absolutt lyssatt», er hentet fra astronomiens metode for å oppdage nye planeter, som er umulig å se for det blotte øye, men er mulig å finne frem til via en kombinasjon av moderne teknologi og matematiske modeller.

Selv sier kunstneren at verket handler om tenkningens uforutsigbarhet, som i likhet med lyskilden svaier fram og tilbake og i korte øyeblikk får skarpe bilder til å fremtre for publikum. Når Mark Seltzer velger å avbilde verket på forsiden av sin bok, har det kanskje mindre med den plutselige muligheten for erkjennelse å gjøre, som med det faktum at Tanakas verk på samme tid tvinger beskueren til å se på projeksjonene på veggen og til å lokalisere projeksjonenes utgangspunkt. Bildene vi ser projisert 
på de hvite veggene kan alltid tilbakeføres til et punkt i rommet. Vi loopes stille inn i selvrefleksjonens forunderlige hamsterhjul.

Historien til - og de estetiske konsekvensene av - denne indirekte og selvrefleksive metoden for å se, er Mark Seltzers undersøkelsesobjekt. Sentralt i utforskningen står den amerikanske forfatteren og tegneserieskaperen Patricia Highsmith, sammen med forfattere som Tom McCarthy, Kazuo Ishiguro, Agatha Christie og Karl Ove Knausgård. I tillegg sørger instrumenter som gyroskopet, teknologier og fenomener som diktafonen, telefonsvareren, twitter, kjedebrev, spillteori og selskapsspill, for å understøtte Seltzers tese om hva som kjennetegner den særegne selvrefleksive måten å oppfatte virkeligheten på i den sene informasjonsalderen, eller den «offisielle verden».

En offisiell verden er nemlig ifølge Seltzer en verden som ikke har noen utside, ingen privatsfære og ingen dybde. Betegnelsen henviser til den fase som følger etter Max Webers «the second modernization», og Seltzers begrep passer dermed sammen med periodiserende begreper som «refleksiv modernisme» av Anthony Giddens og Ulrich Bech: vår tid er ikke kjennetegnet av søket etter nye ressurser og utvidelser av horisonter, men snarere av forsøk på å bruke de ressursene vi har på en mer effektiv måte. Mens de gamle tyske romantikerne gjerne definerte kunsten som et medium som hele tiden reflekterte over seg selv, har det i «den offisielle verden» gått inflasjon i refleksjonen. Refleksjon er blitt cheap, om ikke helt gratis. Utbredelsen av refleksjonen som default i kulturen henger sammen med moderne styringsteknologi og suksessen til kybernetiske eksperimenter: både tekniske og organiske systemer overvåker og justerer seg selv i uendelige feedbacklooper i dag. Refleksjon er med andre ord blitt en operasjon som foregår overalt i naturen og kulturen, og er ikke noe som utmerker kunstverket spesielt, hevder Seltzer. Hele verden består av myriader av selv-refleksive modeller, og det er i siste instans disse modellene som utgjør hva vi kaller virkelighet.

Det er dermed troen på denne allestedsnærværende refleksjonen og på muligheten for modellering av virkeligheten, som Seltzer kaller «den offisielle verden». Boken er delt opp i fem de- 
ler, som hver inneholder et par kapitler. Den første delen bærer navnet «The Daily Planet» og presenterer hovedtrekkene i betegnelsen «den offisielle verden». Del to, «Stationary Carousels and Chain letters», har fokus på ego-tekniske medier - Seltzers (og Peter Sloterdijks) navn på sosiale medier - som blant annet handler om antropoteknikk, altså teknologi utviklet for å forbedre enkeltpersoner, som opprinnelig ble utviklet i Sovjet på 1920-tallet. Del tre handler om sosiale systemer à la Niklas Luhmann og del fire roterer rundt den særlige refleksive modus som kjennetegner den offisielle verden. Siste del omtaler den postoffisielle verden, hvor blant annet Karl Ove Knausgårds Min Kamp leses, som et eksempel på den leden og tilbaketrekningen den offisielle verden produserer i individer.

I Patricia Highsmiths produksjon har Seltzer funnet et særlig krystallklart eksempel på et forfatterskap som helt siden 1950-tallet har jobbet med modellering og skalering av virkeligheten: «the paradoxical economy of Highsmiths narrative mode takes as given the modalization of the world: it absolutizes perspective and scale, and the reflexivity that goes with them»(182), skriver Seltzer. Det er særlig Highsmiths krimfortellinger som fascinerer han. Krimsjangeren fungerer som en slags «perceptual blueprint of this world», idet den hele tiden forsøker å nedskalere verden til menneskene. «Looking, showing, wondering, and realizing in Highsmith looks like this: the correlationism by which the human observer is the measure of all things, not least in a novel in which hundreds of sentences have the phrases 'he thought', or 'he realized' attached to them». Krimsjangeren prøver kontinuerlig å tilpasse «the world to human size» og markerer samtidig «the official limits of that world» (168). Samme modellerte virkelighet, om enn ikke like elegant utført og intellektuelt stimulerende som hos Highsmith, finner man i en annen krimlegendes romaner, Agatha Christies, hvis poetikk kan beskrives som en «observation and re-enactment», hevder den amerikanske akademikeren.

Bokens tittel, og hovedbegrep, «den offisielle verden» minner oss også om kontorlandskapet via den engelske termen «office». Kontoret dukker ifølge Seltzer opp overalt som scene i 
litteraturen fra den siste halvdelen av 1900-tallet og er, som krimsjangeren, uttrykk for en utforskning og en tro på en modellerbar og skalerbar verden. På kontorer, som på åsteder, modelleres virkeligheten hele tiden av registrert data. Et kontor er «a working model of an antiseptic modernity and its indoor social life». Kontoret er en miniatyr av verden utenfor, som ikke egentlig behøver verden utenfor, men har sin egen særlige operative modus. Kontorene skaper en «corridor-world», en verden «that coordinates at every point bodies, reports, communicative media, and spatial arrangements». Kontoret er «the administrative ground floor of a self-denoting world», et «uncanny space» med referanse til Kafkas uendelige trapper og labyrinter i Slottet og Prosessen. Kort sagt, er kontoret en skalerbar versjon av virkeligheten, et system i systemet.

Når Seltzer leser Hightsmith, Kafka og Christie som reaksjoner og videretenkninger av medieteknologiske endringer, gjør han det uten en stringent kobling til konkrete medier, men snarere til en mer abstrakt idé om medier og mediesystemer. På et overordnet plan skriver Seltzer seg dermed inn i en forlengelse av Friedrich Kittlers tese om at medier determinerer vår situasjon: estetikken avslører hvordan vi operasjonaliserer verden, samtidig som blikket alltid reproduseres på et materielt, medieteknologisk nivå. Styrken ved boken er således verken en medieteoretisk eller metodologisk klarhet, snarere er det den særlige lesemåten til Seltzer som utmerker seg, og som man kjenner igjen om man har lest klassikeren Bodies and Machines (1991). Dér kryssleste han blant annet fagforeningsrapporter fra minearbeiderne og Henry James-romaner for å komme nærmere endringen i oppfattelsen av handlekraft og risikovurdering i 1800-tallets USA. I The Official World samleser han populærvitenskapelige bøker, krim, spillteori og teknologihistorie. Metoden hans kan kanskje beskrives som en eklektisk lesemåte med en løs mediehistorisk base; den overordnede tesen om hvordan blikket endres i den offisielle verden driver lesningen av skjønnlitteraturen framover, samtidig som det er skjønnlitteraturen som bærer størsteparten av bevisbyrden for denne endrede måten å se på. 
Noen steder blir det vanskelig å følge de konkrete sprangene til Seltzer, og av og til blir språket dessuten unødvendig komplisert og pregnant. Det kan lett bli enten banalt eller mystifiserende når Seltzer kaller vår tid for «media union», en tid hvor stadig mer er «conditioned by speed, and repeatability, and by a permanent, and asymptiotically continious connectedness». Andre ganger kan det virke som om de finjusterte poengene forsvinner i altfor generelle eksempler. Som for eksempel i kapittelet «Men in self-curved space», hvor Seltzer skriver om Berlinmurens fall. Det var som om, skriver Seltzer, ryktene om at muren var fallet og grensene var åpnet, førte til at muren falt og at grensene ble åpnet: "Wishful thinking, seeded by the news, with the thinking part installed later. And effects with the intentions put in later too: officials on both West and East sides quickly, of course, took credit for die Wende - the turning point - in German and world history». Når man leser dette, spør man seg om ikke årsakskjeden alltid er kaotisk når politiske omveltninger skjer, og hva egentlig Berlinmurens fall kan brukes som eksempel på.

Forankret i bokens overordnede tese, blir imidlertid eksemplenes banalitet omvandlet til en styrke. Seltzer tankesprang er ikke først og fremst argumenter for en verden i en evig feedbackloop, men en oppfattelse av verden som værende i en tilstand av konstant remodellering, evig påvirkelig av oss selv og mediene. Hvorvidt media eller rykter faktisk kan endre verden, er underordnet oppfattelsen av at vår offisielle verden kan regenere seg i selv-refleksive modeller. Seltzers bok handler derfor om den utbredte opplevelsen i dag, av at ting rapporterer og modellerer seg selv, og at vi, om vi vil eller ei, er fanget i dens stadig mer intrikate selvrefleksive system via stadig mer invasive feedbacklooper. Ved således å forsøke å sirkle inn hvordan de medieteknologiske betingelsene, følelsene og blikket de siste 60 årene har endret seg og blitt organisk vevet inn i hverandre, nærmer Seltzer seg mot slutten av The Official World affektteorien, som nettopp forsøker å ta følelser alvorlig som historiske fenomener.

Det er på ingen måte en oppløftende diagnose Seltzer stiller på vår tid. Livet i en offisiell verden er tett sammenkoblet med 
våre drømmer og følelser, og drømmene og begjærene denne selv-refleksive status quo skaper i oss, fremstår verken som særlig produktive eller framtidsrettede. Følelsen av å kunne bli avslørt, og uten egentlig å ville det, ha muligheten til å mikromanage verdens hendelser, skaper porøse oppfattelser av egen handlekraft. Å forstå disse komplekse sammenhengene mellom avmakt, handlekraft og de underliggende medieteknologiske betingelsene later til å bli viktigere fremover, i samfunnet, for den individuelle eksistens, og også i forskningen. Som ledd i denne komplekse utforskningen utgjør Seltzers bok en uunngålig brikke. 


\section{Contributors:}

Edwin A. Abbott (1838-1926) was a theologian, schoolmaster and writer.

Derek Beaulieu is a Canadian poet and publisher.

Solveig Daugaard is a Ph.D. student in literature at Linköping University and writes criticism in Dagblad Information. She is one of the editors of Sensorium Journal.

Johan Fredrikzon is a Ph.D. student in history of ideas at Stockholm University.

Per Isreaelson recently defended his thesis on the media ecologies of the fantastic in literary history at Stockholm University.

Sybille Krämer is professor of theoretical philosophy at Freie Universität Berlin.

Jakob Lien is a Ph.D. student in literature and media history at Linköping University. He is one of the editor of Sensorium Journal.

Ragnild Lome is a Ph.D. student in literature at Linköping University and co-editor of the magazine Vagant. She is one of the editors of Sensorium Journal.

Jesper Olsson is professor at Linköping University, heads the research group LMI and is member of the editing board of the magazine $O E I$.

Jenny Jarlsdotter Wikström is a Ph.D. student in literature and gender studies at Umeå University. 